CONTRATOS PRIVADOS DA ADMINISTRAÇÃO PÚBLICA: UMA ANÁLISE DO REGIME JURÍDICO APLICÁVEL

\author{
TESE DE DOUTORAdo
}

Orientador: Prof. Associado Dr. Edmir Netto de AraúJo

FACULDADE DE DIREITO DA USP

SÃO PAULO

2011 
EDUARDO HAYDEN CARVALHAES NETO

\title{
CONTRATOS PRIVADOS DA ADMINISTRAÇÃO PÚBLICA: UMA ANÁLISE DO REGIME JURÍDICO APLICÁVEL
}

\author{
Tese de Doutorado apresentada à Banca Examinadora da \\ Faculdade de Direito da Universidade de São Paulo, como \\ exigência parcial para a obtenção do título de Doutor em \\ Direito, sob orientação do Prof. Associado Dr. Edmir Netto de \\ Araújo.
}

\section{FACULDADE DE DIREITO DA USP \\ SÃO PAULO \\ 2011}


Banca Examinadora 
A meus pais, Eduardo e Paula, que nunca se cansam de ouvir minhas dúvidas, lamentos e angústias, me incentivando incondicionalmente. 


\section{AGRADECIMENTOS}

É impossível descrever minha gratidão ao Professor Edmir Netto de Araújo em poucas palavras. Mestre dedicado e paciente, há oito anos vem dedicando seu tempo à minha orientação. Sem suas lições, que se estenderam também às salas de aula do Programa de Graduação na Faculdade de Direito da USP durante a monitoria, minha vida acadêmica teria sofrido uma enorme pausa após o bacharelado. $\mathrm{O}$ resultado apresentado nas próximas páginas é fruto direto de tal convívio.

Minha imensa gratidão também à Professora Dinorá $\mathrm{A}$. Musetti Grotti, que não poupa seu tempo nem tampouco nega acesso à sua biblioteca pessoal desde meus primeiros contatos com o Direito Administrativo.

Da mesma forma, o auxílio fornecido pelos membros da banca de qualificação, Professores Floriano de Azevedo Marques Neto e Fernando Dias Menezes de Almeida, com suas críticas e sugestões, foi fundamental ao amadurecimento e aperfeiçoamento de minhas ideias iniciais e ao desenvolvimento deste estudo.

Minha gratidão também à minha querida Juliana Brescovici, que me conheceu já durante a elaboração desta tese e sempre se mostrou compreensiva e paciente, convivendo com meus períodos de imersão e, acima de tudo, me incentivando e acompanhando com muito carinho.

Por fim, mas não menos importante, não poderia deixar de mencionar o apoio que recebi de meus colegas de trabalho de Mundie e Advogados, não só debatendo exaustivamente diversas passagens desta tese, mas também atendendo prontamente a meus pedidos de leitura e revisão, sempre urgentes. Sem eles, este trabalho certamente não seria completado a tenpo.

Despicienda é a constatação de que todas as falhas porventura verificadas por aqueles que se aventurarem a analisar o presente trabalho são somente atribuíveis ao seu Autor, responsável que foi pela sua elaboração. 


\section{RESUMO}

A celebração de negócios jurídicos é fundamental para a Administração Pública. Sem ela, não só sua interação com a sociedade seria precária, como também não conseguiria cumprir com a maior parte dos princípios que regem seu regime jurídico, pois não se mostra autossuficiente. Para formalizar tais negócios jurídicos, o instrumento utilizado é o contrato.

Parte da doutrina defende que tais instrumentos não se enquadram adequadamente no conceito de contrato por conta das peculiaridades que os cingem quando uma das partes pertence à Administração Pública ou está a exercer função que lhe foi delegada pelo Poder Público. De outro lado, aqueles que concordam com a classificação desses instrumentos como contratos dividem-se entre os que acreditam existir um regime jurídico único para todos os contratos da Administração Pública e aqueles que defendem a existência de duas "modalidades" de contratos: os contratos administrativos, regidos predominantemente pelo direito público, e os contratos privados da Administração Pública, que, tendo como objeto negócios jurídicos característicos da vida privada, são regidos predominantemente pelo direito privado. Somos partidários desta última corrente e, diante da escassa literatura pátria sobre os contratos privados da Administração Pública, nos propomos a analisá-los mais detidamente no presente estudo. Assim, dividimos este trabalho em cinco capítulos.

No primeiro deles, apresentaremos nossas considerações iniciais sobre a matéria, fornecendo um apanhado do que a doutrina nacional e estrangeira já produziu sobre o assunto e de como se dividem as opiniões. Tendo em vista que os contratos regidos primordialmente pelo direito privado apresentam grande parte dos traços dos contratos privados, no segundo capítulo analisaremos as características mais relevantes das cláusulas típicas de direito público que integram os contratos administrativos. O terceiro capítulo, por sua vez, é dedicado à verificação da legislação brasileira e os respectivos dispositivos normativos pertinentes aos contratos privados da Administração Pública. No quarto capítulo nos debruçaremos sobre as decisões jurisprudenciais estrangeiras que marcaram o início da distinção entre as duas modalidades de contratos da Administração Pública e no quinto capítulo apresentaremos nossas conclusões, conjuntamente com algumas sugestões que acreditamos sejam pertinentes ao aperfeiçoamento do tratamento da matéria no Brasil.

Palavras-chave: contratos - contratos administrativos - contratos privados Administração Pública - Direito Administrativo - prerrogativas cláusulas exorbitantes - negócio jurídico - licitação. 


\section{ABSTRACT}

The execution of legal businesses is essential for the Public Administration. Without it, not only its interaction with society would be precarious, but also could not comply with most of the principles governing their legal regime, as it is not show selfsufficient. In order to formalize such legal transactions, the instrument to used is the agreement.

Part of the doctrine sustains that such instruments do not fit properly on the concept of agreement because of its peculiarities when one of the parties belongs to the Public Administration or is exercising function that has been delegated by the Public Power. On the other hand, those who agree with the classification of such instruments as agreements are divided between those who believe that there is a single legal regime for all the agreements executed by the Public Administration and those who advocate the existence of two "modalities" of agreements: the administrative agreements, predominantly governed by public law, and private agreements of the Public Administration, which having as subject legal businesses that are typical of the private life, are governed mainly by private law. We agree with this latter view, and because of the scarce literature on private agreements of the Public Administration, we propose to examine them more closely in this study. We have divided this paper into five chapters.

In the first one, we will present our initial thoughts on the subject, providing an overview of what the national and foreign doctrine has produced on the subject and how the opinions are divided. Given that agreements governed by private law primarily present most of the characteristics of private agreements, in the second chapter we will analyze the most relevant characteristics of the typical clauses that integrate the administrative agreements. The third chapter, on its turn, is devoted to the verification of the Brazilian legislation and the respective applicable normative provisions pertaining to the private agreements of the Public Administration. In the fourth chapter we will lean over the foreign court decisions that became the landmarks of the beginning of the distinction between the two modalities of agreements of the Public Administration and in the fifth chapter we will present our findings, together with some suggestions that we believe are relevant to improving the handling of this matter in Brazil.

Key words: agreements - administrative agreements - private agreements - Public Administration - Administrative Law - prerogatives - exorbitant clauses legal business - bid. 


\section{RÉSUMÉ}

La réalisation des affaires juridiques est essentielle pour l'Administration Publique. Sans elle, non seulement son interaction avec la société serait précaire, mais aussi elle ne pourrait pas se conformer à la plupart des principes qui régissent leur statut juridique, puisqu'elle ne se montre pas auto-suffisante. Pour formaliser ces actes juridiques, l'instrument utilisé est le contrat.

Une partie de la doctrine considère que ces instruments ne s'insèrent pas correctement sur la notion de contrat en raison des particularités qui les limitent quand une partie appartient au gouvernement ou bien exerce une fonction déléguée par le Pouvoir Public. D'autre part, ceux, qui acceptent la classification de ces instruments tels que les contrats, sont divisés entre ceux qui croient qu'il y a un régime juridique unique pour tous les contrats de l'Administration Publique et ceux qui préconisent l'existence de deux «modes» de contrats : les Contrats Administratifs, principalement régis par le droit public et les contrats privés de l'Administration Publique, qui ayant comme objet les affaires juridiques, une caractéristique de la vie privée, sont principalement régis par le droit privé. Nous sommes favorables à ce dernier point de vue, compte tenu de la littérature existante, limitée dans notre pays, sur les contrats privés de l'Administration Publique, nous proposons de les examiner de plus près dans cette étude. Nous avons divisé ce travail en cinq chapitres.

Dans le premier, nous présentons nos premières réflexions sur ce sujet en donnant un aperçu de ce que la doctrine nationale et l'étrangère ont dit à ce sujet et comment les opinions se divisent. Étant donné que les contrats régis principalement par le droit privé présentent la plupart des caractères des contrats privés, dans le deuxième chapitre nous analyserons les caractéristiques les plus pertinentes des clauses typiques du droit public qui font partie des contrats administratifs. Le troisième chapitre, à son tour, est consacré à la vérification de la législation brésilienne et les dispositions réglementaires pertinentes relatives aux contrats privés dans l'Administration Publique. Dans le quatrième chapitre, nous verrons les décisions des tribunaux étrangers qui ont marqué le début de la distinction entre deux types de contrats de l'Administration Publique et dans le cinquième chapitre, nous présenterons nos conclusions, ainsi que quelques suggestions que nous jugeons pertinentes pour améliorer le traitement de cette matière au Brésil.

Mots-Clés: contrats - contrats administratifs - contrats privés -Administration Publique Droit Administratif - prérogatives - clauses exorbitantes - affaire juridiquelicitation. 


\section{SUMÁRIO}

INTRODUÇÃO . .9

CAPítulo I. DOS CONTRATOS CELEBRAdOS PELA ADMINISTRAÇÃo PÚBLICA

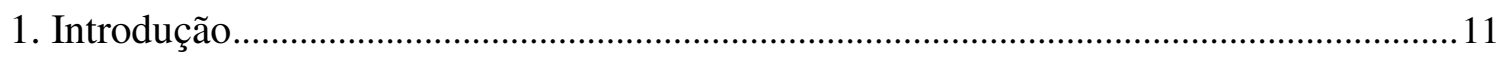

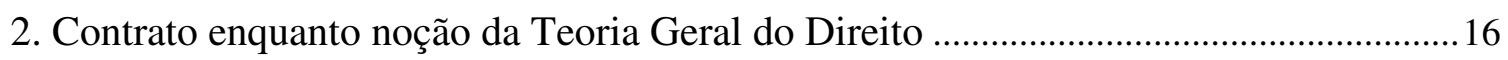

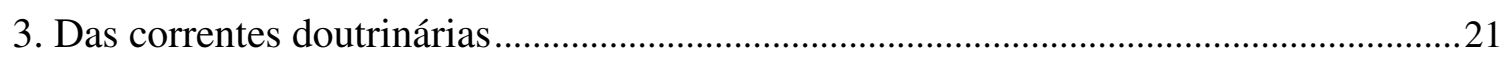

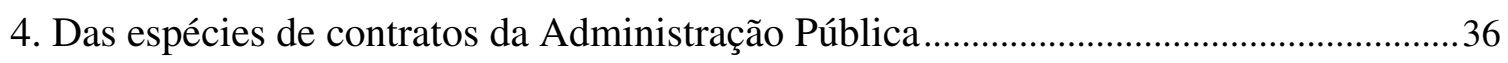

5. Critérios de diferenciação entre modalidades de contratos da Administração Pública...

6. Pontos de proximidade entre as modalidades de contratos da Administração Pública .54

7. Sobre a posição adotada no presente trabalho.

8. Das consequências da aplicação de regime jurídico privado aos contratos celebrados pela Administração Pública

\section{CAPÍTULO II. O PAPEL DAS CLÁUSULAS CARACTERÍSTICAS DE DIREITO} PÚBLICO.

1. Introdução

2. A relação das prerrogativas públicas com os contratos.

3. Semelhanças entre as modalidades de contratos da Administração Pública. .84

\section{CAPÍTULO III. A LEGISLAÇÃO BRASILEIRA E OS CONTRATOS PRIVADOS} DA ADMINISTRAÇÃO PÚBLICA.

1. Das regras gerais da Lei de Licitações e Contratos Administrativos brasileira..............89

2. Da redação dos contratos da Administração Pública conforme a lei

CAPÍTULO IV. AS LIÇÕES ADVINDAS DA JURISPRUDÊNCIA

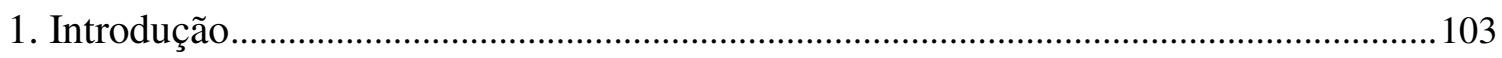

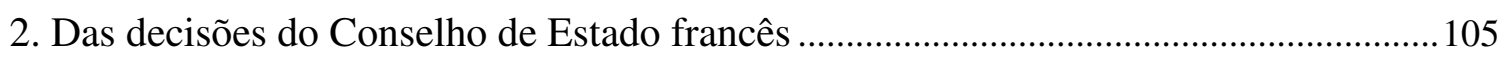

3. Dos exemplos específicos encontrados na jurisprudência pátria .....................................112

CAPÍTULO V. PROGNÓSTICO E CONSTAÇÕES FINAIS..................................................117

1. Nossa opinião acerca do ambiente atual dos contratos da Administração Pública ..... 117

2. Proposta de tratamento legal dos contratos da Administração Pública........................... 120

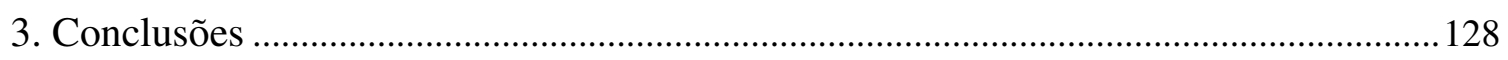




\section{INTRODUÇÃO}

O presente trabalho se volta inicialmente à análise dos contratos privados da Administração Pública. Todavia, trata-se de tema que não pode ser avaliado sem que, indiretamente, também se analise os contratos administrativos e a própria atuação da Administração Pública.

Assim, a idéia central por trás das posições que serão sustentadas e que, por sua vez, fatalmente conduzirão às conclusões apresentadas ao final serão apresentadas é a de que o interesse público é a regra-matriz do Poder Público. É ele quem, em primeiro lugar, legitima a existência da Administração Pública e o mandato que lhe é outorgado para reger a sociedade. Se sua busca for abandonada, então se perde a razão de ser do Estado e caberá a cada indivíduo fazer o possível para impor seus direitos individuais.

Dentro de um contexto de convivência harmônica da Administração Pública com os particulares, esta por vezes apresentará necessidades próprias de pessoa jurídica que precisarão ser supridas por alguém que tenha interesse conciliável. Para isso, em certos momentos será regida pelo direito privado, como destaca Manoel de Oliveira Franco Sobrinho:

\footnotetext{
"A ordem positiva impõe ao Direito Administrativo, em virtude da variedade das relações que estabelece com os administrados, a adoção de instrumentos próprios do Direito Privado. Nisto não vai nada de novo porque toda organização administrativa vem submetida ao ordenamento jurídico, embora quando na atividade fique subordinada a dois propósitos, um de interesse e outro de finalidade pública.

Duas tônicas porém sempre estão presentes, a do interesse público avaliável e a da finalidade pública cogente. Em torno delas, ou da unidade delas, ativa-se a Administração buscando os instrumentos adequados, adotando, para cada figura necessária, o modelo tradicional. O modelo que há de formalizar-se em razão das relações entre as partes."
}

\footnotetext{
${ }^{1}$ FRANCO SOBRINHO, Manoel de Oliveira. Contratos administrativos. São Paulo: Saraiva, 1981. p.
} 262-263. 
Nossa intenção é não só fornecer um panorama da dinâmica entre direito público e direito privado na atuação administrativa, como também entender a lógica por detrás da determinação dos regimes jurídicos aplicáveis, bem como fornecer sugestões de soluções voltadas a mitigar as discussões que prejudicam o pleno desenvolvimento da contratação pela Administração Pública. É a esta tarefa que dedicaremos as próximas páginas. 


\section{CAPÍTULO I. DOS CONTRATOS CELEBRADOS PELA ADMINISTRAÇÃO PÚBLICA}

\section{Introdução}

A Administração Pública desempenha papel fundamental na sociedade contemporânea, coordenando diversos aspectos da vida cotidiana. Para isto, tem que celebrar negócios jurídicos, pois seus integrantes, como quaisquer outras pessoas jurídicas, não são autossuficientes e, portanto, têm que realizar negócios jurídicos para delegar tarefas, obter suprimentos e insumos, contratar serviços e complementar diversos aspectos de suas atividades não só como integrantes do Poder Público, mas também como pessoas jurídicas.

Cada entidade integrante da Administração Pública direta ou indireta tem, obviamente, que conseguir gerir a si própria, para que então possa exercer suas respectivas funções. Cada integrante da Administração Pública é, antes de tudo, uma pessoa jurídica, e como tal se relacionará com todos aqueles que a cercam e que com ela interagem. Para formalizar uma forma específica de interação (os negócios jurídico) que tenha que realizar, cada uma dessas entidades deverá lançar mão dos instrumentos adequados, qual sejam, os contratos.

A noção clássica de contrato é conceito amplamente estudado pelo Direito. Orlando Gomes leciona que "contrato é uma espécie de negócio jurídico que se distingue, na formação, por exigir a presença pelo menos de duas partes", É, portanto, negócio bilateral ou plurilateral. Além disso, o contrato é a ferramenta adequada para formalizar as vontades das partes envolvidas, consignando um acordo composto de direitos e obrigações.

Para Maria Helena Diniz, "contrato é o acordo entre a manifestação de duas ou mais vontades, na conformidade da ordem jurídica, destinado a estabelecer uma regulamentação de interesses entre as partes, com o escopo de adquirir, modificar ou

${ }^{2}$ GOMES, Orlando. Contratos. 17. ed. Rio de Janeiro: Forense, 1997. p. 4. 
extinguir relações jurídicas de natureza patrimonial"3. Seus traços característicos residem (i) na consensualidade para formação do vínculo e (ii) na autoridade de seus termos, que se impõem igualmente para os contratantes.

O Código Civil francês atual ${ }^{4}$, ao contrário do brasileiro, traz uma definição de contrato, que é "uma convenção por meio da qual uma ou diversas pessoas se obrigam, com uma ou diversas outras a dar, fazer ou não fazer alguma coisa" (art. 1.101").

Para José Cretella Júnior, "contrato é o acordo recíproco de vontades, consubstanciado em normas jurídicas, que passam a reger a vontade dos contratantes." 6

Como formaliza vontades conciliáveis (alguns Autores afirmam que as vontades das partes envolvidas seriam contrapostas, enquanto outros as classificam como coincidentes; o fato é que, independentemente do ponto de vista daquele que as analisa, todas as partes chegam a um consenso), o contrato exerce função de pacificação social do convívio entre pessoas que se relacionam por opção ou por necessidade para celebrar negócios jurídicos.

Quando o negócio jurídico envolve apenas entes privados no exercício de suas funções cotidianas da vida civil, é inegável que o regime jurídico regente dos contratos correspondentes será igualmente privado. Todavia, quando a coletividade envolvida no negócio jurídico é integrada pela Administração Pública e/ou por ente privado no exercício de função que lhe foi delegada legitimamente pela Administração Pública, surge a necessidade de se analisar qual o regime jurídico aplicado ao negócio: se o privado, o público ou, ainda, uma mistura de ambos.

Com efeito, não se denota, a priori, qualquer característica que delimite a aplicação do instituto do contrato apenas no ramo do direito privado ou do direito público, pois é fato que há diversas situações que conclamam a Administração Pública a celebrar negócios jurídicos com outras figuras administrativas ou com particulares. Tendo em vista que, num Estado de Direito, ninguém pode ser compelido a celebrar negócio jurídico sem que assim

\footnotetext{
${ }^{3}$ DINIZ, Maria Helena. Tratado teórico e prático dos contratos. 2. ed. São Paulo: Saraiva, 1996. v. 1, p. 9. ${ }^{4}$ Que, no tocante ao art. 1.101, preserva a redação original do Código Napoleônico de 1804.

${ }^{5}$ Tradução livre. No original: "Art. 1.101. Le contrat est une convention par laquelle une ou plusieurs personnes s'obligent, envers une ou pplusieurs autres, à donner, à faire ou à ne pas faire quekque chose."

${ }^{6}$ CRETELla JÚNIOR, José. Direito administrativo comparado. 4. ed. Rio de Janeiro: Forense, 1992. p. 234.
} 
o deseje, haverá, via de regra, consentimento das partes envolvidas no negócio.

A princípio, portanto, tais negócios jurídicos poderm - e devem - ser formalizados por meio de contratos. No entanto, a questão se torna mais complexa ao se analisar a relação entre o significado de contrato (vinculação obrigacional entre as partes) e a lógica de ação da Administração Pública (busca incessante do interesse público no exercício do mandato que lhe é outorgado).

Para melhor se compreenda a atuação administrativa formalizada por meio de contratos, convém apresentar o que Diogo Freitas do Amaral ${ }^{7}$, em utilíssima lição, acredita serem os principais corolários do princípio da supremacia do interesse público:

(a) Somente a lei pode definir os interesses públicos, não podendo ela própria fazê-lo, consequência dos princípios da legalidade estrita e da sepraração de poderes, de maneira a evitar as tentações absolutistas, totalmente inadequadas a um Estado Democrático de Direito;

(b) A noção de "interesse público" é, por natureza, vaga, tratando-se de conceito aberto que comporta atividade interpretativa, de maneira que é impossível definir de antemão o seu conteúdo de maneira exata, exaustiva, concreta e rígida;

(c) A lei não define completa e exaustivamente cada um dos interesses públicos e, para aplicar aplicações de caráter legislativo (amplas e genéricas) entra em campo o papel da Administração Pública, de interpretá-los e atuar dentro dos limites da própria lei e em conformidade com os princípios que a regem, no exercício de seu poder discricionário, para verificar a pertinência e a oportunidade de atuar (sempre, conmtudo, vinculada aos fatores supra descritos $)^{8}$. Trata-se, na verdade, de uma decorrência do corolário anteriormente descrito;

(d) Uma vez o interesse público encontrando guarida em lei, sua prossecução é dever da Administração Pública;

(e) A Administração Pública também deve observar o "princípio da especialidade", segundo o qual a sua capacidade jurídica e competência encontram-se delimitadas pelo interesse público, pois o mandato que lhe foi outorgado pela sociedade somente lhe atribui prerrogativas ${ }^{9} \operatorname{com}_{0}$

\footnotetext{
${ }^{7}$ AMARAL, Diogo Freitas do. Direito administrativo. 1. ed. Coimbra: Almedina, 1988, v. 2. p. 37-39.

${ }^{8}$ Especificamente sobre este assunto, ver MARQUES NETO, Floriano de Azevedo. Regulação estatal e interesses públicos. São Paulo: Malheiros Ed., 2002, obra na qual o Autor aborda com maestria a tarefa de regulação amparada na escolha entre diferentes interesses públicos.

${ }^{9}$ Diogo de Figueiredo Moreira Neto define prerrogativas como "os institutos que expressam algum tipo de situação privilegial dos órgãos da Administração em certas relações jurídicas, tais como sobressaem no fisco, na polícia e nos serviços públicos" (MOREIRA NETO, Diogo de Figueiredo. O futuro das cláusulas exorbitantes nos contratos administrativos. In: ARAGÃO, Alexandre Santos de, MARQUES NETO, Floriano de Azevedo (Coords.). Direito administrativo e seus novos paradigmas. Belo Horizonte: Fórum, 2008. p. 571).
} 
fim único de que possa buscar o bem coletivo;

(f) As ações ou omissões da Administração Pública devem ter por base um interesse público determinado em lei. Apenas tal interesse público constitui "motivo principalmente determinante" legítimo para atuação ou omissão administrativa. Contrario sensu, as atuações ou omissões desconformes constituirão desvio de poder;

(g) Quando a Administração Pública atuar com vistas a interesse privado, ao invés de interesse público, tal atuação poderá ser classificada como "corrupção". Isto não quer dizer que, caso existam direitos privados que acabem por ser atendidos na busca do interesse público, constituam ação irregular, mas sim que a finalidade primária de toda atuação ou omissão administrativa deve ser o interesse público; e

(h) A Administração Pública deve sempre adotar as melhores soluções possíveis para cada caso concreto, pois o princípio da prossecução do interesse público é decorrência do "dever de boa administração".

A idéia geral transmitida por estes corolários integra uma premissa que norteará o presente trabalho: a de que o princípio da supremacia do interesse público deve nortear toda ação da Administração Pública, quer praticada em regime privado, quer praticada em regime público ou mesmo misto. Para isto, poderá fazer uso das prerrogativas que lhe são atribuídas por conta de sua natureza jurídica intrínseca pública (que não se confunde com o regime jurídico de seus atos).

No entanto, para evitar eventuais abusos, a atuação administrativa deve sempre estar adstrita aos limites legais, assim como agir em conformidade com os princípios da impessoalidade, moralidade, publicidade, eficiência, especialidade, prossecução do interesse público, observância das competências e dos direitos fundamentais e os demais listados pela Constituição Federal. Trata-se do conceito de "autonomia privada" adaptado à Administração Pública apresentado por Maria João Estorninho ${ }^{10}$ : naquelas situações em que sua atuação se dê sob a égide do direito privado, haverá margem discricionária de atuação e liberdade para contratar, desde que observados os deveres cristalizados no ordenamento jurídico em vigor. Ainda que formalmente idêntica à dos particulares, a autonomia do Poder Público quando atua sob a égide do direito privado possui diferenças (limites) significativos em sua substância.

\footnotetext{
${ }^{10}$ ESTORNINHO, Maria João. Direito europeu dos contratos públicos: um olhar português. Coimbra: Almedina, 2006. p. 207-221.
} 
Da mesma forma, a atuação administrativa (incluindo a que se manifesta por meio de contratos) deve ser devidamente motivada ${ }^{11}$ e sua veiculação deve ser pública. Deve ser exercida com razoabilidade e proporcionalidade, apenas afetando direitos de terceiros na estrita medida do necessário, buscando a conciliação sempre que possível.

Naqueles casos em que se deparar com a necessidade de conciliação com outro(s) interesse(s) público(s), entrará em campo a discricionariedade administrativa, que, sopesando os interesses públicos que se contrapõem, verificará aquele que deve prevalecer (e que somente prevalescerá na estrita medida do necessário). Tal processo, obviamente, deverá ser trazido a públuico e amplamanete motivado, oferecendo oportunidade de manifestação àqueles que venham a ser afetados.

Tendo em vista que integram o conjunto de ações da Administração Pública, todos os contratos celebrados por seus integrantes e/ou representantes deverão ser conduzidos com vistas à prossecução do interesse público, independentemente do regime jurídico que lhes seja aplicável. A prova concreta de que esta é uma realidade no ordenamento jurídico pátrio é o fato de que mesmo contratos privados da Administração Pública, via de regra, devem ser precedidos por certames licitatórios, nos termos da Lei Federal n. ${ }^{\circ}$ 8.666/1993, que a contratação deve dispor de dotação orçamentária correspondente, que o Poder Público continuará adstrito à observância dos limites estabelecidos pela Lei de Responsabilidade Fiscal (Lei Complementar n. ${ }^{\circ}$ 101/2000) e que as demais peculiaridades da atuação administrativa serão aplicáveis.

O conceito de contrato como é visto atualmente tem origem no Código Napoleônico de $1804^{12}$, o qual, por meio de seu art. 1.134, ao erigir as avenças contratuais à condição de lei entre as partes, instituiu o princípio que vincula as partes aos termos do negócio jurídico formalizado, que prevalesce até os tempos atuais. Trata-se de característica fundamental ao êxito dos negócios jurídicos.

Como a sociedade é dinâmica e a Administração Pública possui situação jurídica peculiar por conta da necessidade de fazer valer o interesse público, cria-se um potencial de

\footnotetext{
${ }^{11}$ Característica essa que vincula a atuação ao motivo exposto, chamada pela doutrina de "teoria da vinculação dos motivos determinantes".

${ }^{12}$ Este, que foi o primeiro Código de relevância da Idade Moderna, procurou atender aos anseios da classe social que então se destacava, a burguesia. Ao acatar a doutrina dos direitos dos homens, procurou estabelecer certo equilíbrio entre indivíduo e Estado, na tentativa de harmonizar os preceitos do direito romano com o direito público, conferindo maior autonomia aos administrados. Por esta razão, desempenhou papel significativo na história evolutiva dos negócios jurídicos e no relacionamento entre Estado e sociedade.
} 
conflito entre preservação do acordo e busca do interesse público, que sendo instável, pode vir a contrariar o que fora previamente acordado. Tal conflito latente pode ser verificado nas duas modalidades de contratos da Administração Pública e será um dos principais objetos de estudo do presente trabalho.

\section{Contrato enquanto noção da Teoria Geral do Direito}

Convém desde já fixar uma premissa que guia o presente trabalho, devidamente observada por Edmir Netto de Araújo, no sentido de que "na verdade, contrato é noção de Teoria Geral do Direito, e mais exatamente uma categoria jurídica" e que sua conceituação "não se situa em qualquer dos ramos ou disciplinas em que se divide a ciência do Direito, público ou privado, Direito Civil, Comercial, Constitucional, Administrativo etc."13. De tal lição decorre a possibilidade de existir tanto contrato regido primordialmente pelo direito privado quanto contrato majoritariamente submetido ao regime jurídico público ${ }^{14}$.

\footnotetext{
${ }^{13}$ ARAÚJO, Edmir Netto de. Curso de direito administrativo. 4. ed. São Paulo: Saraiva, 2009. p. 626. Maria Sylvia Zanella Di Pietro compartilha da mesma opinião, afirmando que "o conceito de contrato não é específico do direito privado, devendo ser dado pela teoria geral do direito. Ele existe também no âmbito do direito público, compondo a espécie contrato de direito público, que, por sua vez, abrange contratos de direito internacional e de direito administrativo." DI PIETRO, Maria Sylvia Zanella. Direito administrativo. 18. ed. São Paulo: Atlas, 2005. p. 242 (grifos no original). A mesma Autora observa que "o contrato administrativo, a fundação pública, o ato administrativo, o bem público, a responsabilidade civil do Estado, estào sujeitos a normas e princípios específicos do direito administrativo, que permitem distingui-los dos institutos equivalentes do direito civil. Mas as suas peculiaridades não afetam, na essência, a sua natureza nem impedem o seu enquadramento na noção categorial de contrato, fundação, ato jurídico, bem e responsabilidade" (DI PIETRO, Maria Sylvia Zanella. Ainda existem os chamados contratos administrativos? In: ___ _ RIBEIRO, Carlos Vinícius Alves. Supremacia do interesse público e outros temas relevantes do direito administrativo. São Paulo: Atlas, 2010. p. 400).

${ }^{14}$ Nesse sentido, Miguel Angel Berçaitz observa que "el contrato no es una figura exclusiva Del derecho privado. Existe también el de derecho administrativo con elementos comunes AL contrato de derecho privado, pero con elementos diferentes que derivan de su contenido, de su fin, de los intereses distintos que afecta y de su régimen jurídico próprio" (BERÇAIT, Miguel Angel. Teoría general de los contratos administrativos. Buenos Aires: Depalma, 1952. p. 108). De se notar que Oswaldo Aranha Bandeira de Mello critica tal posição, defendendo que no âmbito da Administração Pública haveria apenas acordos de vontades, convenção, ato bilateral, união entre partes, por conta do fato de seu conteúdo ser estipulado por apenas uma das partes (Administração Pública) e pela possibilidade de exercício de prerrogativas unilaterais (BANDEIRA DE MELLO, Oswaldo Aranha. Princípios gerais de direito administrativo. 3. ed. Rio de Janeiro: Forense, 2007. v. 1, p. 682-690; e BANDEIRA DE MELLO, Oswaldo Aranha. Contrato de direito público ou administrativo. Revista de Direito Administrativo, Rio de Janeiro, n. 88, p. 25-26, 1967). Destarte, Oswaldo Aranha Bandeira de Mello acredita estar o conceito de contrato umbilicalmente ligado apenas ao ramo do direito privado.
} 
Opinião semelhante à de Edmir Netto de Araújo é apresentada por Maria Sylvia Zanella Di Pietro ${ }^{15}$, para quem o contrato, sendo instituto definido pela Teoria Geral do Direito, deve ser enquadrado nas "categorias jurídicas", cuja definição dada por José Cretella Júnior é "formulação genérica, in abstracto, com índices essenciais, mas gerais, não comprometida ainda com nenhum dos ramos do direito" ${ }^{, 16}$.

A mesma Autora ressalta que também Sebastián Retortillo ${ }^{17}$ traz em suas lições a noção de "superconceito", que ele, partindo de situações concretas, fatos e coisas, chega, em uma segunda fase, a definição geral e abstrata resultante num "conceito superior que abrace e compreenda os conceitos parciais, referentes às diversas formas do mesmo instituto".

O reconhecimento de que o contrato é, portanto, uma noção da Teoria Geral do Direito, uma categoria jurídica ou superconceito é essencial à compreensão dos contratos celebrados pela Administração Pública e, por conseguinte, também do presente trabalho.

Com efeito, o contrato é uma matriz, que pode ser moldada e aplicada a qualquer ramo do Direito, desde que lhe sejam preservados os componentes caracterizadores. E tal preservação não deve ser interpretada como necessidade de manter cada um dos componentes integralmente idêntico.

Orlando Gomes ${ }^{18}$ prefere dividir os elementos de validade do contrato em duas categorias: extrínsecos (pressupostos) e intrínsecos (requisitos). Ao tratar da validade do negócio jurídico, tal Autor anumera os componentes do contrato que podem ser classificados em cada uma destas categorias:

\begin{abstract}
"Pressupostos são as condições sob as quais se desenvolve e pode desenvolver-se o contrato (Ferrara). Agrupam-se em três categorias, conforme digam respeito: $1^{\circ}$ ) aos sujeitos; $2^{\circ}$ ) ao objeto; $3^{\circ}$ ) à situação dos sujeitos em relação ao objeto. Todo contrato pressupõe:
\end{abstract}

\footnotetext{
${ }^{15}$ DI PIETRO, Maria Sylvia Zanella. Ainda existem os chamados contratos administrativos?, cit., p. 399.

${ }^{16}$ CRETELLA JÚNIOR, José. As categorias jurídicas e o direito público. Revista da Faculdade de Direito da Universidade de São Paulo, São Paulo, ano 62, fasc. 2, p. 214, 1967. O mesmo Autor também coloca: "A noção de contrato é categorial, porque exprime uma figura jurídica, que não é peculiar nem ao direito público nem ao direito privado, cabendo sua conceituação à teoria geral do direito" (CRETELLA JÚNIOR, José. Direito administrativo comparado, cit., p. 234).

${ }^{17}$ RETORTILLO, Sebastián. Il diritto vivile nella genesi del diritto amministrativo e dei suoi listituti. Rivista Trimestrale di Diritto Pubblico, Milano, v. 9, p. 698-735, 1959.

${ }^{18}$ GOMES, Orlando. Contratos. 18. ed. Rio de Janeiro: Forense, 1999. p. 45-46.
} 
a) capacidade das partes;

b) idoneidade do objeto;

c) legitimação para realizá-lo.

Esses pressupostos devem estar presentes no momento em que o contrato se realiza ou alcança vigor (Betti). São, portanto, extrínsecos, embora se integram posteriormente na relação contratual. Mas, não bastam. A lei exige outras condições para o contrato cumprir sua função econômicosocial típica.

São requisitos complementares, considerados elementos intrínsecos indispensáveis à validade de qualquer contrato:

a) o consentimento;

b) a causa;

c) o objeto

d) a forma.

Porque os pressupostos e os requisitos se completam, confundem-se, apesar de serem elementos diversos. Por simplificação, diz-se que são requisitos essenciais à validade do negócio jurídico: a capacidade do agente, a possibilidade do objeto e a forma, esta quando prescrita em lei. Sendo o contrato negócio jurídico bilateral, a vontade dos que o realizam requer exame à parte, por ser particularização que precisa ser acentuada. Assim, o acordo das partes adquire importância especial entre os elementos essenciais dos negócios jurídicos bilaterais. É, de resto, sua força propulsora."

Por sua vez, Manoel de Oliveira Franco Sobrinho enumera as condições de validade dos contratos celebrados especificamente pela Administração Pública:

"Num regime jurídico natural, ordenado de garantias, está claro que a legalidade faz princípio fundamental, que a lei está na origem do ato permissivo do contrato. Não são somente pressupostos teóricos que atuam na formação dos contratos administrativos, sim fatores que, na realidade, dão-lhe conteúdo na especialidade. Ou condições, vamos dizer, que resultam na seguinte equação:

a) capacidade + legitimidade $=$ competência contratual;

b) competência + objeto possível e lícito = capacidade contratual.

Desintegrando, à primeira vista, um contrato administrativo, temos:

a) a lei fundamentando a permitida manifestação de vontade; 
b) a vontade manifestada através de pessoa jurídica administrativa;

c) a pessoa capaz na organização submetida a regime de competência;

d) a competência vinculada à natureza do serviço público a prestar;

e) o serviço lícito e possível integrado no interesse estatal administrativo;

f) o co-contratante particular aceitando as condições oferecidas;

g) o acordo consensual estabelecendo relações recíprocas nos direitos e nas obrigações;

h) a formalização e a consequente adjudicação da obra ou serviço.

A inexistência, ou a falta, de um dos seis primeiros elementos, invalida o contrato administrativo, tornando-o viciado e ineficaz. Quanto aos dois últimos, decorrem dos seis primeiros afetando o particular e comprometendo a administração. Regrando situações, só revisáveis pelo descumprimento do pactuado. Situações que só se tornam anuláveis diante da inviabilidade dos efeitos." 19

Em se tratando a noção de contrato passível de aplicação em diferentes ramos do direito, os seus elementos podem igualmente sofrer adaptações de acordo com o ramo de aplicação, desde que tal adaptação não seja tão profunda a ponto de descaracterizá-los ${ }^{20}$ ou desnaturá-los.

Essa constatação foi refletida pelo legislador pátrio na redação do caput do art. 54 da Lei Federal de Licitações e Contratos Administrativos (Lei Federal n. ${ }^{\circ}$ 8.666/1993):

"Art. 54. Os contratos administrativos de que trata esta Lei regulam-se pelas suas cláusulas e pelos preceitos de direito público, aplicandose-lhes, supletivamente, os princípios da teoria geral dos contratos e as disposições de direito privado." (destacamos)

\footnotetext{
${ }^{19}$ FRANCO SOBRINHO, Manoel de Oliveira. Os contratos administrativos na sua existência jurídicopositiva. Revista de Direito Administrativo, Rio de Janeiro, n. 138, p. 38-39, out./dez. 1979.

${ }^{20}$ Além disso, como qualquer outro conceito jurídico, também os elementos do contrato apresentam modificações não só ao longo do tempo, mas também de acordo com o local em que são aplicados, sem, contudo, deixarem de compor a mesma noção. Trata-se do que chamamos de mutabilidade espaço-temporal, fenômenos decorrente do próprio fato de o direito, enquanto ciência humana, sofrer alterações decorrentes da aplicação de seus conceitos pelo homem.
} 
Como consignado acima, se os elementos essenciais dos contratos são consensualidade, bilateralidade ou plurilateralidade, conformidade com a ordem jurídica e a intenção de versar sobre relações jurídicas, não há nenhum deles que elimine, de pronto, a possibilidade de uma das partes ser a Administração Pública, confirmando assim a lição de Edmir Netto de Araújo.

Da mesma forma, como se sabe, o Código Civil (Lei Federal n. ${ }^{\circ} 10.406 / 2002$ ), ao tratar das obrigações, não estipula qualquer elemento que, por si só, torne impossível a participação da Administração Pública em um contrato.

O contrato pode assumir diversas formas e ser celebrado sob a égide de diferentes regimes jurídicos. É nesse contexto que podemos observar a existência dos contratos administrativos, definidos pelo Prof. Hely Lopes Meirelles como "o ajuste que a Administração Pública, agindo nessa qualidade, firma com particular ou outra entidade administrativa para a consecução de objetivos de interesse público, nas condições estabelecidas pela própria Administração"21.

Para Marçal Justen Filho, o contrato administrativo em sentido amplo (entendido como todo e qualquer contrato do qual a Administração Pública seja parte) é "o acordo de vontades destinado a criar, modificar ou extinguir direitos e obrigações, tal como facultado legislativamente e em que pelo menos uma das partes atua no exercício da função administrativa",22.

Sobre sua origem, Maria João Estorninho afirma:

\begin{abstract}
"Historicamente, o contrato administrativo não resultou de qualquer 'fatalidade', mas antes de um 'acaso', fruto de uma especial interpretação do princípio da separação de poderes e do princípio da repartição de competência jurisdicional; assim, verificou-se primeiro a autonomização processual de certos contratos da Administração e, só num segundo momento, teve início a substantivização da figura do contrato administrativo". ${ }^{23}$
\end{abstract}

\footnotetext{
${ }^{21}$ MEIRELLES, Hely Lopes. Direito administrativo brasileiro. 28. ed. São Paulo: Malheiros Ed., 2003. p. 200-201. Há que se ressaltar que todo contrato é um acordo de vontades, mas nem todo acordo de vontades é um contrato.

${ }^{22}$ JUSTEN FILHO, Marçal. Curso de direito administrativo. 4. ed. São Paulo: Saraiva, 2009. p. 352.

${ }^{23}$ ESTORNINHO, Maria João. Réquiem pelo contrato administrativo. Coimbra: Almedina, 2003. p. 183.
} 
Gaston Jèze é tido por grande parte da doutrina como o "pai da teoria dos contratos administrativos" ${ }^{24}$, teoria esta que, nas palavras de Georges Vedel e Pierre Delvolvé, ele teria desenvolvido "quase que do nada" 25 . No entanto, como já mencionado acima, os contratos celebrados pela Administração Pública podem ser regidos pelo direito público (caso em que são comumente denominados "contratos administrativos") ou pelo direito privado.

\section{Das correntes doutrinárias}

Como em qualquer outro ramo da ciência jurídica, também no tocante aos contratos da Administração Pública não há consenso sobre sua regulação. Muitos doutrinadores, realizando uma análise superficial do assunto, acabam por reconhecer apenas a existência dos contratos administrativos, descartando a existência de contatos de natureza predominantemente privada, cometendo equívoco bem ilustrado pela passagem abaixo:

"Temos dito que a Administração é como um Rei Midas. Este, tudo que
tocava virava ouro. A Administração, onde toca, publiciza. Se se tem a
presença da Administração Pública, tem-se junto, necessariamente, o
ingresso do regime jurídico administrativo e a presença das chamadas
cláusulas exorbitantes do direito comum."

Não é esse o nosso entendimento. Tendo em vista a pluralidade de atividades do cotidiano da Administração Pública, entendemos que algumas destas atividades são realizadas enquanto órgão, pessoa jurídica submetida ao regime comum, de Direito Civil, enquanto outras permanecem condicionadas ao Direito Público. Isto não quer dizer - e

\footnotetext{
${ }^{24}$ Georges Péquignot afirmava, em 1953, que "até uma data relativamente recente, os publicistas estavam contentes de analisar e de descrever individualmente os mais importantes contratos da Administração: os negócios de trabalho público, os negócios de fornecimento, as concessões de serviço público, sem tentar sistematizar as regras comuns a tais contratos, e determinar as regras gerais aplicáveis a todos os contratos da Administração. Agora já é possível, após M. G. Jèze ter se devotado ao problema com os três volumes que ele dedica aos contratos nos seus 'Princípios Gerais de Direito Administrativo' (T. IV, 1934; T. V, 1936; T. VI, 1936), apresentando uma teoria geral dos contratos da Administração" (PÉQUIGNOT, Georges. Des contrats administratifs. Paris: Librairies Techniques, 1953. p. 3).

${ }^{25}$ VEDEL, Georges; DELVOLVÉ, Pierre. Droit administratif. 12. ed. Paris: Presses Universitaires de France, 1994. v. 1, p. 369, tradução livre.

${ }^{26}$ DALLARI, Adilson Abreu. Contrato de obra pública. Cadernos Fundap, São Paulo, ano 5, n. 11, p. 29, jul. 1985.
} 
voltaremos de maneira mais detida a este ponto no curso do presente trabalho - que a Administração Pública propriamente dita não continue tendo de observar o regime jurídico administrativo, mas sim que determinados atos/contratos são diretamente afetados pelo Direito Civil. Obviamente, como melhor se demonstrará adiante, os limites entre o Direito Civil e o Direito Administrativo nem sempre são claros, nem tampouco facilmente determináveis. Esclarecer tal questão é a tarefa que se propõe para o presente trabalho.

Existem grandes controvérsias entre os doutrinadores a respeito dos chamados contratos administrativos, sendo possível identificar na doutrina pelo menos três correntes principais $^{27}$ :

1. Corrente da negação da existência de contratos da Administração Pública;

2. Corrente que a Administração Pública celebra contratos e que todos eles devem ser classificados como contratos administrativos; e

3. Corrente que aceita a existência do gênero "contratos da Administração Pública" e que estes podem ser classificados nas espécies "contrato administrativo", com regime jurídico de direito público, derrogatório e exorbitante do direito comum e “contratos de regime predominantemente privado".

Os adeptos da primeira corrente tomam como premissa que os princípios da igualdade entre as partes, da autonomia da vontade e da força obrigatória das convenções seriam caracterizadores de todo e qualquer contrato. Nesse contexto, argumentam os estudiosos que o contrato administrativo não apresenta a observância a tais princípios como regra, pelo que tais instrumentos, celebrados no campo do direito público, não poderiam ser considerados propriamente "contratos".

\footnotetext{
${ }^{27}$ A respeito das três correntes doutrinárias, ver BANDEIRA DE MELLO, Celso Antônio. Contrato administrativo. Revista dos Tribunais, São Paulo, v. 562, p. 37-38. É de se ressaltar, todavia, a existência de correntes intermediárias. Neste sentido, Maria João Estorninho, reconhecedora da existência de contratos privados da Administração Pública, que “os chamados 'contratos privados' da Administração não podem ser considerados absolutamente idênticos aos dos particulares e, pura e simplesmente, ser votados ao esquecimento; o reconhecimento do fenômeno de publicização da actividade administrativa de direito privado obriga a que todos os contratos da Administração sejam encarados em termos idênticos." Para tal Autora, ö regime jurídico do contrato administrativo é, em si mesmo, compatível com o Direito contratual comum; aliás, isto temsido progressivamente admitido pelos próprios defensores do contrato administrativo, à medida que os administrativistas foram perdendo o çomplexo de exorbitância'em relação ao Direito Privado". (ESTORNINHO, Maria João. Réquiem pelo contrato administrativo, cit., p. 183-184).
} 
Com relação ao primeiro princípio mencionado, afirma-se não estar presente nos instrumentos celebrados pela Administração Pública porque esta ocupa posição de supremacia em relação ao particular. Por sua vez, a autonomia da vontade é destacada como inexistente por tal corrente, quer do lado da Administração, quer do lado do particular que com ela contrata: a autoridade administrativa só faz aquilo que a lei determina (aplicação do princípio da legalidade estrita) e o particular submete-se a cláusulas regulamentares ou de serviço, fixadas unilateralmente pela Administração Pública, em obediência ao que decorre da lei. Como os poderes da Administração advêm de lei, não lhes poderão ser negados mesmo que as cláusulas contratuais silenciem acerca deles. Como se percebe, para tal corrente a autonomia das vontades não seria respeitada em sua forma plena por não haver uma negociação efetiva entre as partes sobre o conteúdo do instrumento a ser celebrado.

Finalmente, o princípio da força obrigatória das convenções (pacta sunt servanda), seria também desrespeitado no "contrato administrativo", em decorrência da mutabilidade das cláusulas regulamentares, que permite à Administração promover alterações unilaterais no contrato. Isso ocorre porque a autoridade administrativa, por estar vinculada ao princípio da indisponibilidade do interesse público ${ }^{28}$, não poderia sujeitar-se a cláusulas inalteráveis, como ocorre no direito privado.

Essa posição foi adotada, no direito brasileiro, entre outros, por Oswaldo Aranha Bandeira de Mello $^{29}$. Segundo ele, as cláusulas regulamentares decorrem de ato unilateral da Administração Pública, vinculado à lei, sendo as cláusulas econômicas estabelecidas por contrato de direito comum.

No caso, por exemplo, da concessão, referido Autor entende que pode haver contrato apenas quanto à equação econômico-financeira da relação, como ato jurídico complementar adjeto ao ato unilateral ou ato-união da concessão. $\mathrm{O}$ ato por excelência, que é a concessão de serviço público ou de uso de bem público propriamente dita é, para ele, unilateral; o ato acessório, que diz respeito ao equilíbrio econômico, é contratual. Não se poderia definir a natureza de um instituto por um ato que é apenas acessório do ato

\footnotetext{
${ }^{28}$ Tratando-se de interesse público, que por natureza é extra commercium, não se poderia cogitar de um particular possuir senhoria sobre o mesmo de forma idônea.

${ }^{29}$ BANDEIRA DE MELLO, Oswaldo Aranha. Princípios gerais de direito administrativo. Rio de Janeiro: Forense, 1969. v. 1, p. 681-687. Celso Antônio Bandeira de Mello filia-se à mesma corrente.
} 
principal. E mesmo esse contrato não é administrativo, por ser inalterável pelas partes da mesma forma que qualquer contrato de direito privado ${ }^{30}$.

Os críticos de tal corrente recorrem ao argumento de que o fato de o gênero “contrato" pertencer à Teoria Geral do Direito - e não a um ramo específico da ciência jurídica - faz com que suas características possam sofrer pequenas alterações de acordo com o campo de aplicação. Sobre o assunto, Maria Sylvia Zanella Di Pietro explica:

"Tal doutrina incide no mesmo erro que incidiam aqueles que, em meados do século passado, negavam que o contrato administrativo fosse verdadeiramente um contrato; que a propriedade pública fosse realmente propriedade; que os direitos reais fossem verdadeiramente direitos reais. Incidem no erro de somente considerar esses institutos à luz do direito civil, como se os conceitos nele formulados fossem compreensivos de toda a realidade que que constitui objeto de estudo do direito. Eles colocam o conceito geral, a noção categorial, o superconceito, no direito civil e não na teoria geral do direito. É o que fazem aqueles que pretendem enquadrar, por exemplo, o contrato administrativo no conceito de contrato formulado pelo direito civil, com a consequência inevitável de lhe negarem a existência como tal e não o enquadrarem em categoria própria, específica do direito administrativo." ${ }^{\text {}}$

Ademais, não se pode olvidar que a própria Constituição Federal brasileira reconhece expressamente que a Administração Pública pode sim celebrar contratos, quando (i) prevê que as obras, serviços, compras e alienações serão contratados mediante processo de licitação pública (art. 37, $\mathrm{XXI}^{32}$ ); (ii) determina que os contratos celebrados por

\footnotetext{
30“'Os contratos entre a Administração pública e os particulares são equiparáveis aos contratos de direito privado. Correspondem aos contratos pertinentes à equação econômico-financeira das concessões de obras ou de serviços públicos, complementares a êsses atos administrativos, ou, aos considerados pelo Código Civil, embora possam se reger, ademais por regras jurídicas especiais, complementares previstas por lei ou regulamento ou por cláusulas dispostas pela Administração pública, no edital ou ofício de convocação dos interessados, em desenvolvimento aos textos legais e regulamentares, aos quais a outra parte adere, e passam a ser objeto do acôrdo de vontades.

Certo, a êsses contratos precedem atos administrativos unilaterais ou convencionais, mas que se não confundem com os contratos. Assim, ao contrato sôbre a equação econômico-financeira das concessões de obras ou de serviços públicos, antecede o ato-união da concessão. Êste é o ato jurídico principal do qual o contrato sôbre a equação econômico-financeira é simplesmente adjeto. Com referência aos outros contratos antecedem os atos unilateraispreliminares à sua feitura. Destarte, pode tocar ao Legislativo fixar os têrmos gerais dos contratos ou autorizar o Executivo a efetivá-los. E a êste compete processar a escolha dos candidatos mediante tomada de preços ou concorrência, conforme o caso, e verificar as condições de idoneidade dos proponentes e as melhores ofertas, nos têrmos legais e regulamentares. Aliás, o mesmo ocorre com o próprio ato-união de concessão. Tais atos são, no entanto, distintos dos contratos ou do atounião da concessão." (BANDEIRA DE MELLO, Oswaldo Aranha. Contrato de direito público ou administrativo, cit., p. 33).

${ }^{31}$ DI PIETRO, Maria Sylvia Zanella. Ainda existem os chamados contratos administrativos?, cit., p. 401.

32، Art. 37. A administração pública direta e indireta de qualquer dos Poderes da União, dos Estados, do
} 
empresas públicas e sociedades de economia mista se sujeitaro a regime jurídico especial, distinto daquele aplicável aos demais contratos da Administração Pública (art. 22, XXVII ${ }^{33}$ e $173, \S 1^{\circ}, \mathrm{III}^{34}$ ); (iii) dispõe sobre contratos de concessão (art. 175, parágrafo único, $\mathrm{I}^{35}$ ); e (iv) aborda os contratos celebrados pela União com empresas estatais ou privadas para viabilizar atividades econômicas sujeitas ao monopólio do Estado (art. 177, §1 ${ }^{\circ 36}$ ); e (v) a possibilidade de a Administração Pública celebrar contratos de trabalho (art. 37, I, II e IX ${ }^{37}$

Distrito Federal e dos Municípios obedecerá aos princípios de legalidade, impessoalidade, moralidade, publicidade e eficiência e, também, ao seguinte:

$(\ldots)$

XXI - ressalvados os casos especificados na legislação, as obras, serviços, compras e alienações serão contratados mediante processo de licitação pública que assegure igualdade de condições a todos os concorrentes, com cláusulas que estabeleçam obrigações de pagamento, mantidas as condições efetivas da proposta, nos termos da lei, o qual somente permitirá as exigências de qualificação técnica e econômica indispensáveis à garantia do cumprimento das obrigações."

33“"Art. 22. Compete privativamente à União legislar sobre:

(...)

XXVII - normas gerais de licitação e contratação, em todas as modalidades, para as administrações públicas diretas, autárquicas e fundacionais da União, Estados, Distrito Federal e Municípios, obedecido o disposto no art. 37, XXI, e para as empresas públicas e sociedades de economia mista, nos termos do art. $\left.173, \S 1^{\circ}, \mathrm{III} ;(\ldots)\right)^{\prime}$

34،“Art. 173. Ressalvados os casos previstos nesta Constituição, a exploração direta de atividade econômica pelo Estado só será permitida quando necessária aos imperativos da segurança nacional ou a relevante interesse coletivo, conforme definidos em lei.

$\S 1^{\circ}$ A lei estabelecerá o estatuto jurídico da empresa pública, da sociedade de economia mista e de suas subsidiárias que explorem atividade econômica de produção ou comercialização de bens ou de prestação de serviços, dispondo sobre:

(...)

III - licitação e contratação de obras, serviços, compras e alienações, observados os princípios da administração pública; (...)"

35، Art. 175. Incumbe ao Poder Público, na forma da lei, diretamente ou sob regime de concessão ou permissão, sempre através de licitação, a prestação de serviços públicos.

Parágrafo único. A lei disporá sobre:

I - o regime das empresas concessionárias e permissionárias de serviços públicos, o caráter especial de seu contrato e de sua prorrogação, bem como as condições de caducidade, fiscalização e rescisão da concessão ou permissão; (...)"

36“Art. 177. Constituem monopólio da União:

(...)

$\S 1^{\circ}$ A União poderá contratar com empresas estatais ou privadas a realização das atividades previstas nos incisos I a IV deste artigo observadas as condições estabelecidas em lei."

37، Art. 37. A administração pública direta e indireta de qualquer dos Poderes da União, dos Estados, do Distrito Federal e dos Municípios obedecerá aos princípios de legalidade, impessoalidade, moralidade, publicidade e eficiência e, também, ao seguinte:

I - os cargos, empregos e funções públicas são acessíveis aos brasileiros que preencham os requisitos estabelecidos em lei, assim como aos estrangeiros, na forma da lei;

II - a investidura em cargo ou emprego público depende de aprovação prévia em concurso público de provas ou de provas e títulos, de acordo com a natureza e a complexidade do cargo ou emprego, na forma prevista em lei, ressalvadas as nomeações para cargo em comissão declarado em lei de livre nomeação e exoneração;

(...)

IX - a lei estabelecerá os casos de contratação por tempo determinado para atender a necessidade temporária de excepcional interesse público; (...)" 
e art. $39^{38}$ ). É patente que o Constituinte adotou a terminologia "contrato" em expresso reconhecimento da existência de contratos propriamente ditos no âmbito do Poder Público.

Há parte da doutrina (ainda que minoritária), que procura identificar a figura dos contratos à das normas jurídicas infralegais editadas pelo Poder Público com função reguladora ou organizacional ${ }^{39}$. Todavia, não se deve confundir os contratos da Administração Pública com normas jurídicas editadas pelo Poder Público, pois, ao contrário destas, os contratos não são gerais e abstratos, referindo-se a um negócio jurídico e a partes específicos e determinados, sendo que os direitos e obrigações gerados dependem do consentimento originador do instrumento para se aperfeiçoar, enquanto as normas são oponíveis "erga omnes" independentemente de qualquer manifestação de vontade do particular.

A segunda corrente doutrinária entende que a Administração Pública efetivamente celebra contratos, mas que todos eles são contratos administrativos; o que não existiria seria o contrato de direito privado em que seja parte a Administração Pública, porque em todos os acordos de que participa há sempre a interferência do regime jurídico administrativo.

\footnotetext{
38،Art. 39. A União, os Estados, o Distrito Federal e os Municípios instituirão conselho de política de administração e remuneração de pessoal, integrado por servidores designados pelos respectivos Poderes. $\S 1^{\circ}$ A fixação dos padrões de vencimento e dos demais componentes do sistema remuneratório observará: I - a natureza, o grau de responsabilidade e a complexidade dos cargos componentes de cada carreira;

II - os requisitos para a investidura;

III - as peculiaridades dos cargos.

$\S 2^{\circ}$ A União, os Estados e o Distrito Federal manterão escolas de governo para a formação e o aperfeiçoamento dos servidores públicos, constituindo-se a participação nos cursos um dos requisitos para a promoção na carreira, facultada, para isso, a celebração de convênios ou contratos entre os entes federados. $\S 3^{\circ}$ Aplica-se aos servidores ocupantes de cargo público o disposto no art. $7^{\circ}$, IV, VII, VIII, IX, XII, XIII, XV, XVI, XVII, XVIII, XIX, XX, XXII e XXX, podendo a lei estabelecer requisitos diferenciados de admissão quando a natureza do cargo o exigir.

$\S 4^{\circ} \mathrm{O}$ membro de Poder, o detentor de mandato eletivo, os Ministros de Estado e os Secretários Estaduais e Municipais serão remunerados exclusivamente por subsídio fixado em parcela única, vedado o acréscimo de qualquer gratificação, adicional, abono, prêmio, verba de representação ou outra espécie remuneratória, obedecido, em qualquer caso, o disposto no art. 37, X e XI.

$\S 5^{\circ}$ Lei da União, dos Estados, do Distrito Federal e dos Municípios poderá estabelecer a relação entre a maior e a menor remuneração dos servidores públicos, obedecido, em qualquer caso, o disposto no art. 37, XI.

$\S 6^{\circ}$ Os Poderes Executivo, Legislativo e Judiciário publicarão anualmente os valores do subsídio e da remuneração dos cargos e empregos públicos.

$\S 7^{\circ}$ Lei da União, dos Estados, do Distrito Federal e dos Municípios disciplinará a aplicação de recursos orçamentários provenientes da economia com despesas correntes em cada órgão, autarquia e fundação, para aplicação no desenvolvimento de programas de qualidade e produtividade, treinamento e desenvolvimento, modernização, reaparelhamento e racionalização do serviço público, inclusive sob a forma de adicional ou prêmio de produtividade.

$\S 8^{\circ}$ A remuneração dos servidores públicos organizados em carreira poderá ser fixada nos termos do $\S 4^{\circ}$." (não adentraremos na discussão da ADIN n. ${ }^{\circ}$ 2.135-4 no tocante a este dispositivo).

${ }^{39}$ Como, por exemplo, resoluções, portarias, instruções normativas etc.
} 
Agustín Gordillo, por exemplo, defende que atualmente todos os contratos da Administração Pública são administrativos porque, em sua opinião, todos eles têm incidência - em maior ou menor intensidade - do direito público. Isto não o impede, todavia, de sugerir a divisão dos contratos em três grande grupos, de acordo com o nível de incidência do direito privado. Para o Autor, mesmo aqueles contratos típicos do direito privado (compra e venda de imóveis, doação, locação ${ }^{40}$, permuta empréstimo etc.) "não se mantêm sempre com suas características típicas civilistas" ${ }^{41}$.

\footnotetext{
${ }^{40}$ Nesse sentido, Acórdão da Apelação Cível n. ${ }^{\circ}$ 92.03.71000-0, julgado em 05/09/2000, cuja ementa é a que segue: "CIVIL - DESPEJO - DENÚNCIA VAZIA - LEI 6649/79 - LOCAÇÃO RESIDENCIAL.

1 - O contrato firmado entre a empresa pública e o particular insere-se dentre os contratos subordinados ao regime jurídico privado, porquanto regido por normas de direito civil.

2 - A solução do caso concreto deve ser encontrada na antiga lei de locação 6649/79 que somente foi revogada com a edição da lei $n .^{\circ} 8245 / 91$.

3 - Considerando-se que a lei não exige que o locador justifique a retomada do imóvel por ocasião do término do contrato de locação e não cuidando a espécie de locação residencial, cabível o despejo por denúncia vazia nos termos da lei . $^{\circ} 6649 / 79$.

4 - Aelo improvido."

${ }^{41}$ "En suma, los contratos que celebra la administración tienen todos un régimen en parte de derecho público, pero que no es uniforme; todos pueden ser denominados 'contratos administrativos', pero no tienen igual régimen jurídico entre sí, pues existen gradaciones en cuanto a la intensidad del régimen de derecho público.

Si antiguamente podíamos encontrar dos categorías bien definidas y totalmente opuestas de contratos de la administración, los civiles y administrativos, hoy en cambio encontramos un acercamiento de los extremos, que no alcanza a ser total y que deja subsistentes matices susceptibles de agrupación en tres grandes conjuntos.

Dentro de esa zona cubierta por los contratos administrativos corresponde ubicar como más próximos al derecho administrativo clásico de fines del siglo pasado y comienzos del presente, a las concesiones y licencias de servicios públicos en condiciones monopólicas o de exclusividad, al contrato de empréstito público interno y, en menor medida, a la concesión de obra pública. Se trata de la aplicación más intensa del derecho público.

Un segundo grupo se integra con el contrato de función pública, la concesión y el permiso de uso del dominio público y privado del Estado; en menor grado, los contratos de suministros y obra pública.

Más cerca del derecho privado encontramos al contrato de compraventa de inmuebles, al de locación y luego a los demás contratos: cesión, permuta, donación, préstamo, etc. que, bueno es reiterarlo, no se mantienen siempre con sus típicos caracteres civilistas.

El contrato de crédito externo, enteramente sometido al derecho privado de la jurisdicción en que se celebra y ejecuta el contrato, está por el momento excluído de nuevas contrataciones, lo cual parece un paso necesario para al ajuste de las cuentas públicas." (GORDILLO, Agustín. Tratado de derecho administrativo: parte general. Buenos Aires: Macchi. Buenos Aires: F.D.A., 2003. t. 1, p. XI-38/XI-39. Disponível em: <www.gordillo.com>. Acesso em: 26 ago. 2010). Opinião semelhante é a de Manoel de Oliveira Franco Sobrinho, para quem haveria apenas contratos administrativos dentre aqueles celebrados pela Administração Pública, que seriam divididos em (a) contratos de atribuição e de colaboração (com finalidade de substituição da Administração Pública pelo particular em atividades passíveis de delegação); (b) contratos nominados na sua tipicidade (delegação limitada de atividades); e (c) contratos interadministrativos (celebrados entre duas ou mais entidades públicas). Conforme FRANCO SOBRINHO, Manoel de Oliveira. op. cit., p. 33-43.
} 
No tocante à competência ${ }^{42}$, à forma, ao procedimento, à finalidade, aplica-se sempre o direito público, e não o direito privado. É o que ocorreria mesmo nos contratos de compra e venda, locação, doação, comodato, contratação de obra artística, seguro, quando celebrados pelo Poder Público. Trata-se da posição adotada por José Roberto Dromi ${ }^{43}$, Agustín Gordillo $^{44}$, Lúcia Valle Figueiredo ${ }^{45}$, Juarez Freitas ${ }^{46}$, Jessé Torres Pereira Júnior e Allan R. Brewer-Carias.

Nos dizeres desse último Autor:

“A Administração, portanto, se bem que preponderantemente regulada pelo Direito Administrativo, na atualidade está submetida tanto ao Direito Público como ao Direito Privado e sua atividade, regida por ambos os ramos, será sempre uma atividade administrativa. Não há, na realidade, atividade privada da Administração. Assim como não existem atos privados da Administração, tampouco existem, claramente, contratos de direito privado da Administração. A atividade da Administração - e, em geral, a de todos os sujeitos de de direito administrativo - está submetida a um regime preponderante de direito administrativo ou preponderante de direito privado, mas isto não autoriza a concluir que na primeira hipótese a atividade seja administrativa e, na segunda, seja privada." ${ }^{47}$

Mesmo diante do fato de alguns autores ${ }^{48}$ adeptos desta corrente de pensamento reconhecerem que a Administração Pública poderia atuar segundo seus interesses econômicos, interesses privativos seus, enquanto pessoa jurídica, acreditam que isto não

\footnotetext{
${ }^{42}$ Apenas a título de curiosidade, a Cámara Nacional de Apelaciones en lo Civil y Comercial Federal argentina já consolidou entendimento no sentido de que "existem contratos da Administração parcialmente regrados pelo Direito privado, dos quais esta se socorre quando realiza uma atividade industrial ou comercial. Em tais casos se aplicará o Direito civil ou comercial para regrar ao menos o objeto do ato, embora a competência pareça ser sempre disciplinada pelo Direito administrativo." (CNFedContAdm, Sala III, 29/3/83, ED, 106-96, tradução livre. No original: "Existen contratos de la Administración parcialmente reglados por el Derechoprivado, a los que ésta acude cuando realiza una actividad industrial o comercial. En tales casos se aplicará el Derecho civil o comercial para reglar ao menos el objeto del acto, aunque la competencia parezca siempre disciplinada por el Derecho administrativo.").

${ }^{43}$ DROMI, Roberto. La licitación pública. 2. ed. Buenos Aires: Astrea, 1977. p. 16-18.

${ }^{44}$ GORDILLO, Agustín. Tratado de derecho administrativo: parte general. Buenos Aires: Macchi. 7. ed. Belo Horizonte: Del Rey, 1991. t. 2, p. XI-9 e ss.

${ }^{45}$ FIGUEIREDO, Lúcia Valle. Curso de direito administrativo. 6. ed. São Paulo: Malheiros Ed., 2003. p. 496-497.

${ }^{46}$ FREITAS, Juarez. Estudos de direito administrativo. São Paulo: Malheiros Ed., 1997. p. 178.

${ }^{47}$ BREWER-CARÍAS, Allan R. Evolução do conceito de contrato administrativo. Revista de Direito Público, São Paulo, ano 10, v. 51/52, p. 5-19, jul./dez. 1979.

${ }^{48}$ A doutrina alemã no passado, guiada por Otto Mayer, defendia que a Administração Pública ora atuava em defesa dos interesses públicos, ora como um "empresário privado" (MAYER, Otto. Derecho administrativo alemán. Tradução de Horacio H. Heredia e Ernesto Krotoschin. Buenos Aires: Depalma, 1949. t. 1, p. 188), também chamada de Administração Fiscal ou Administração Patrimonial. Esta Teoria do Estado Fiscal, que segundo Duguit foi defendida durante muito tempo na França por Théophile Ducrocq, alegava que o Estado possui duas personalidades, e posteriormente foi muito criticada tanto na França quanto na Alemanha por Michoud e Jellinek (DUGUIT, Leon. Les transformations du droit public. Paris: Librairie Armand Colin, 1913. Reimpressão La Mémoire du Droit, 1999. p. 162-163).
} 
levaria necessariamente à celebração de contratos privados por ela. Neste contexto, para tais autores, a busca desses interesses, que Renato Alessi consagrou pela terminologia de interesses secundários ${ }^{49}$, não se confunde com a possibilidade de celebração de contratos privados pela Administração Pública.

Nossa visão é a de que os contratos privados são, na verdade, negócios jurídicos dos quais a Administração Pública é parte enquanto pessoa jurídica e que, por não haver peculiaridade quanto à sua figuração em tal relação jurídica, não há justificativa para que se aplique regras que extrapolam o direito ordinário.

Mesmo a Administração Pública, consubstanciada em pessoa jurídica, possui ritos comuns, que se equiparam aos de qualquer outra pessoa jurídica. $\mathrm{O}$ observador mais afoito afirmará que, mesmo nestes casos, o direito público se aplica, mesmo que em menor proporção. Ora, como se sabe, aceitar que o direito público incide sobre a Administração Pública (parte) não exclui a possibilidade de haver contrato (instrumento) predominantemente privado da Administração Pública. A própria legislação brasileira assim determina, como demonstraremos adiante.

A terceira posição, adotada pela maioria dos administrativistas brasileiros, é justamente a que compartilha da visão descrita acima, admitindo a existência de contratos administrativos e de contratos privados da Administração Pública, sendo que aqueles possuem características próprias que os distinguem do contrato de direito privado. Veja-se, a respeito, a posição dos professores Edmir Netto de Araújo, Maria Sylvia Zanella Di Pietro, Marçal Justen Filho, Renée Chapus e André de Laubadère. ${ }^{50}$

\footnotetext{
${ }^{49}$ Renato Alessi, utilizando lições de Carnelutti e Picardi, fez distinção entre interesse público primário (interesse público strcto sensu e legítimo) e interesse público secundário, destacando que este somente poderia ser buscado quando correspondesse àquele (conforme ALESSI, Renato. Sistema instituzionale del diritto amministrativo italiano. 3. ed. Milano: Giuffrè, 1960. p. 197).

${ }^{50}$ ARAÚJO, Edmir Netto de. op. cit., p. 632 e ss e p. 639 e ss.; DI PIETRO, Maria Sylvia Zanella. Direito administrativo. 16. ed. São Paulo: Atlas, 2004. p. 240-241 e Da aplicação do direito privado no direito administrativo. 1988. Tese (Livre Docência) - Faculdade Direito, Universidade de São Paulo, São Paulo, 1988. p. 167 e ss.; JUSTEN FILHO, Marçal. Teoria geral das concessões de serviço público. São Paulo: Dialética, 2003. p. 158-159. A mesma opinião do Autor pode ser verificada em sua obra Comentários à Lei de Licitações e Contratos Administrativos. 7. ed. São Paulo: Dialética, 2000, p. 40. Tal autor faz uma observação interessante sobre aqueles que criticam o uso da terminologia "contrato" no âmbito do direito administrativo: "Então, como contrato não é conceito originariamente nascido no campo do direito público, os caracteres fundamentais e peculiares à figura contratual relacionam-se com o direito privado. Justamente por isso, a possibilidade (e a conveniência) da utilização da figura contratual no âmbito do direito público exige cautelas que, usualmente, não são adotadas. Grande parte das disputas acerca da estrutura do "contrato administrativo' derivam da importação descuidada de institutos de direito privado para o direito público" (Teoria geral das concessões de serviço público, cit., p. 152). Nesse ponto, insta ressaltar que a doutrina majoritária francesa defende que os contratos administrativos se diferenciam dos contratos civis da
} 
Esta corrente doutrinária deriva do direito francês. Naquele país, dotado de dualidade de jurisdição - na qual o Conselho de Estado é o órgão competente para analisar questões de direito público ${ }^{51}$-, o reconhecimento de duas modalidades de contratos da Administração Pública tem implicância não somente quanto à averiguação do regime jurídico do negócio, mas também sobre o Tribunal competente para analisá-lo.

A propósito, é ilustrativa a lição ministrada por Gaston Jèze, com relação ao regime jurídico dos contratos da Administração Pública, para quem

\begin{abstract}
"Para que tais regras especiais se apliquem, não basta que um contrato seja celebrado pela Administração com um particular para a prestação de uma coisa ou um serviço. Mais do que isto, é necessário que o contrato tenha por objeto assegurar o funcionamento de um serviço público. E mesmo este novo elemento não é mais o suficiente: é indispensável que as partes contratantes tenham tido a intenção de se submeter a um regime jurídico exorbitante do direito civil, ao regime de direito público. (...) Então, por meio dos contratos celebrados para assegurar o funcionamento de um serviço público, há duas categorias: $1^{\circ}$ Aqueles que que são contratos ordinários, regidos pelo Código Civil; $2^{\circ}$ Aqueles que são contratos administrativos, submetido às regras especiais de direito público." 52 .
\end{abstract}

André de Laubadère, autor de uma das mais completas obras clássicas sobre o tema $^{53}$, aponta a distinção entre os dois tipos de contratos da Administração Pública como

Administração justamente em função da presença das “cláusulas exorbitantes"). Nesse mesmo sentido, WALINE, Marcel. Précis de droit administratif. Paris: Montchrestien, 1969. v. 1, p. 394. Francis-Paul Benoit parte de um pressuposto um pouco diferente: em princípio todo contrato seria de direito privado, somente sendo diferenciado aquele que possuísse conteúdo estranho a tal regime jurídico, como estipulações características do direito público (BENOIT, Francis-Paul. Le droit administratif français. Paris: Dalloz, 1968. p. 597); LAUBADÈRE, André de; VENEZIA, Jean-Claude; GAUDEMET, Yves. Droit administratif. 17. ed. Paris: L.G.D.J., 2002. p. 264 e ss.

${ }^{51}$ Leon Duguit estabelecia o critério de definição da competência sobre um ato ou contrato administrativo por meio da análise de eventual relacionamento com um serviço público: "[f]finalement aujourd'hui toute question de compétence se ramène à Ceci: ládministration est-elle ou non assignée à raison d'un acte se rattachant au fonctionnement d'um service public? Si oui, la competénce est administrative; sinon elle est judiciaire" (DUGUIT, Leon. op. cit., p. 169).

${ }^{52}$ JÈZE, Gaston. Les príncipes généraux du droit administratif. 3. ed. Paris: Dalloz, 2004, t. 3, p. 305, tradução livre. No original: “[p]our que sés règles spéciales s'appliquent, il ne suffit pas qu'un contrat soit passe par l'administration avec um particulier pour la prestation d'une chose ou d'un service. Il faut, de plus, que le contrat ait pour objet d'assurer le fonctionnement d'un service publique. Et même ce novel élément ne suffit encore pas: il est indispensable que les parties contractantes aient voulu se sumettre à um regime juridique exorbitant du droit civil, au regime du droit public. (...) Dês lors, parmi les contrats conclu em vue d'assurer lê fonctionnement d'un service public, il y a deux catégories: $1^{\circ}$ Ceux qui sont des contrats ordinaires, régis par le Code Civil; $2^{\circ}$ Ceux qui sont des contrats administratifs, soumis aux règles spéciales du droit public".

${ }^{53}$ LAUBADÈRE, André de. Traité théorique et pratique des contrats administratifs. Paris: Librairie Générale de Droit et de Jurisprundence, 1956. t. 1. 
sendo fundamental ao estudo dos negócios jurídicos administrativos ${ }^{54}$.

A corrente doutrinária que defende que os instrumentos celebrados pela Administração Pública para formalizar os negócios jurídicos que realiza não são contratos propriamente ditos sofre grande influência do direito alemão e do direito italiano, tradicionalmente privatistas 55 .

Há, no entanto, duas subdivisões desta corrente, que divergem entre si: enquanto alguns autores entendem que os negócios jurídicos da Administração Pública não podem ser caracterizados como contratos propriamente ditos (e, neste caso, seriam efetivamente atos administrativos unilaterais ${ }^{56}$ ), outros defendem que a Administração Pública pode sim celebrar contratos, mas todos eles serão contratos de direito privado. Tal corrente aponta as diferenças existentes entre os contatos celebrados pela Administração Pública e os atos unilaterais e as normas jurídicas para aproximar os instrumentos formalizadores de negócios jurídicos da Administração à figura do contrato.

A dificuldade de parte da doutrina em classificar os instrumentos celebrados pela Administração Pública como contratos decorre de seu apego a determinadas características apresentadas pela maioria dos contratos, celebrada entre partes privadas. Assim, os Autores que negam a natureza contratual dos instrumentos celebrados pela Administração Pública defendem que para haver consensualidade no negócio jurídico deveria haver negociação propriamente dita entre as partes. Sem ela, para tais Autores o instrumento formalizador do

\footnotetext{
54،Il est aujourd'hui et depuis longtemps acquis que la théorie des contrats de l'administration repose sur la distinction fondamentale des contrats administratifs proprement dits e des contrats de droit commun (ou de droit prive) conclus par l'administration. (...) Les règles que qui s'appliquent aux contrats du droit commun sont em rpincipe celles du Code Civil; celles qui régissent les contrats administratifs sont des règles de droit public, dégagées pour la plupart par la jurisprudence des tribunaux administratifs eux-mêmes." (LAUBADĖRE, André de. op. cit., t. 1, p. 8-9).

${ }^{55}$ É essencial notar, porém, que mesmo no direito alemão atualmente se admite uma dualidade de regimes para contratos da Administração Pública, afastando-se das lições de Otto Mayer, outrora prevalescentes. Neste sentido, Hartmut Maurer leciona que, via de regra, a Administração Pública pode editar um ato administrativo unilateral ou celebrar contrato de direito público, mas que aqueles negócios que não se enquadrem em tais hipóteses poderão gerar a celebração de contrato de direito privado (conforme MAURER, Hartmut. Direito administrativo geral. Tradução de Luís Afonso Heck. Barueri: Manole, 2006. p. 408-409).

${ }^{56}$ Sobre o assunto, muito embora reconheça que a Administração Pública muitas vezes age por meio de ato administrativo unilateral, Leon Duguit defende que mesmo assim há casos de contrato propriamente dito: "[s]i beaucoup d'actes administratifs sont des actes unilatéraux, beaucoup aussi sont des actes contractuels. Um accord de volonté se forme entre um agent public et un autre individue t cette déclaration contractuelle de volonté est alors lê support de l'acte administratif. On n'a pu d'ailleurs découvrir, quelques efforts qu'on ait faits, um critérium permettant de dire dans quels cas l'administration peut agir par voie contractuelle. Pour chaque espèce il faut procéder à une analyse des circonstances et rechercher si em fait il y a les éléments d'um contrat ou d'un acte unilateral" (DUGUIT, Leon. op. cit., p. 159).
} 
negócio passaria simplesmente a ser um ato unilateral. Esquecem-se, no entanto, que mesmo nos negócios celebrados entre particulares nem sempre há uma negociação dos termos contratuais - e, mesmo quando tal negociação existe, ela não envolve necessariamente uma discussão cláusula a cláusula do contrato -, como, por exemplo nos contratos de adesão, tão comuns no direito contemporâneo.

Da mesma forma, o instrumento que formaliza o negócio jurídico sofre modificações de acordo com o regime jurídico das localidades em que é celebrado e também decorrentes da época em que é celebrado. No entanto, tais modificações não desnaturam os elementos caracterizadores de um contrato e, assim, o instrumento continua a pertencer à noção da Teoria Geral do Direito consubstanciadora do contrato.

Nesse sentido, Maria Sylvia Zanella Di Pietro leciona:

“(...) [C]abe lembrar que, dentro do próprio direito privado, muitas figuras conservam o seu nome desde o direito romano, porém foram sofrendo alterações no decurso do tempo, assumindo uma diferença substancial muito mais profunda do que aquela que se pode observar entre uma figura jurídica privada e a correspondente construção administrativa; e estas diferenças substanciais não impedem que se mantenha o conceito geral unitário, compreensivo de todas as variações assumidas pelo instituto.

O contrato, por exemplo, que nasceu como instituto que traz implícita a ideia de liberdade e de igualdade entre as partes, bem como de respeito à vontade e aos interesses individuais, evoluiu de tal forma que hoje se fala em sua função social e econômica exercida sob a égide de normas de ordem pública, inderrogáveis pela vontade das partes. Não obstante, continua a enquadrar-se no conceito geral de contrato como acordo de vontades gerador de efeitos jurídicos. ${ }^{, 57}$

Muito embora a intenção da Administração Pública possa ser notada nas minutas de contratos por ela propostas, tais instrumentos não são marcados pela imperatividade, eis que o administrado somente celebrará o contrato caso concorde com este, caracterizando, assim, a existência de acordo de vontades. Caso o administrado, diante da minuta de contrato proposta pelo Poder Público como parte do edital de licitação, não se interesse pelo negócio jurídico em questão, nem mesmo participará do certame.

${ }^{57}$ DI PIETRO, Maria Sylvia Zanella. Ainda existem os chamados contratos administrativos?, cit., p. 401. 
Assim, os contratos não podem ser confundidos com atos unilaterais da Administração, pois mesmo a presença de cláusulas que representam características peculiares da Administração Pública não afeta sua natureza contratual. O exercício de tais cláusulas sim consubstancia ato unilateral, como, ademais, também o são os pagamentos, a outorga de garantias, a publicação de edital e diversos outros que concorrem para a formação do contrato e/ou decorrem do seu teor.

Como bem observa Carlos Ari Sundfeld ${ }^{58}$, os contratos celebrados pela Administração Pública são efetivamente contratos porque são resultado de acordo de vontades, com interesses contrapostos (objetivo da Administração em ver uma necessidade satisfeita de um lado e interesse de cunho patrimonial daquele que contrata com ela de outro) e equivalência de direitos e obrigações ${ }^{59}$.

Para nós, por trás desta divisão da doutrina usualmente apresentada pelos autores, há um apego demasiado à terminologia e a detalhes que não afetam a natureza jurídica dos conceitos. A discussão quanto à possibilidade de denominar o ato que formaliza um negócio jurídico da Administração Pública de "contrato" é rasa. Ora, um ato praticado pela Administração Pública obviamente não é idêntico a um praticado por um particular, mas nem por isto deixa de ser um ato jurídico.

Se é fato (i) que a Administração Pública realiza negócios jurídicos e (ii) que o direito privado incide, em maior ou menor proporção, sobre o cotidiano da Administração Pública, então é decorrência lógica que há que se estudar de que maneira o direito privado incide sobre a atuação administrativa e o que o delimita.

Como já dissemos, tendo em vista que no Brasil há jurisdição una ${ }^{60}$, utilizar ou não a terminologia "contrato" não modificará o que de fato ocorre entre o particular e a Administração Pública que são partes do negócio jurídico formalizado. Também é fato que o particular somente se tornará parte de um relacionamento com a Administração Pública (possua tal relacionamento condições peculiares ou não) caso assim deseje.

\footnotetext{
${ }^{58}$ SUNDFELD, Carlos Ari. Licitação e contrato administrativo de acordo com as Leis n. 8.666/93e 8.883/94. São Paulo: Malheiros Ed., 1994. p. 212.

${ }^{59} \mathrm{O}$ que não significa, todavia, que direitos e obrigações das partes são idênticos entre si.

${ }^{60}$ Decorrência do inciso XXXV do art. $5^{\circ}$ da Constituição Federal ("a lei não excluirá da apreciação do Poder Judiciário lesão ou ameaça a direito").
} 
Assim, parece ser mais importante analisar como o direito público e o direito privado incidirão sobre o relacionamento administrado/Administração do que se debruçar sobre a interminável discussão da exatidão da nomenclatura "contrato".

Muito embora adotemos no presente trabalho a corrente originada no direito administrativo francês, admitindo existirem contratos administrativos e contratos privados da Administração como gêneros - ou modalidades - dos contratos da Administração Pública, acreditamos que o objeto de estudo é relevante mesmo para aqueles que, discordando de nós, defendem outras correntes doutrinárias que não admitam tal divisão, pois fatalmente se depararão com a necessidade de verificar em qual medida pode o direito privado incidir sobre a atuação da Administração Pública (quer sobre um ato jurídico unilateral, quer sobre um contrato administrativo ou qualquer outra terminologia que prefiram adotar para se referir aos negócios jurídicos da Administração Pública).

Com efeito, importa desde o momento inicial da análise que se promoverá no presente trabalho ressaltar que, como em qualquer ciência humana, não há uma divisão estanque entre o direito público e o direito privado em matéria de contratos. Assim, não só não há contrato em que a Administração Pública seja parte que apenas conte com dispositivos regidos pelo direito público, como também não se verifica a existência de contratos submetidos integralmente ao regime jurídico público.

Nesse sentido, quando se faz referência a "contratos privados da Administração Pública", na verdade quer-se dizer contratos regidos predominantemente pelo direito privado, que são os negócios jurídicos típicos da vida privada (tais como os de compra e venda, locação, doação, comodato, contratação de obra artística, seguro etc. ${ }^{61}$ ), que o Poder Público celebra enquanto pessoa jurídica, e não como parte do exercício de sua função pública.

Mutatis mutandis, quando alguém se refere a contrato administrativo ou contrato público, quer-se dizer aqueles contratos que, em grande parte, submetem-se ao regime jurídico público, mas que nem por isto deixam de contar com certas cláusulas e formalidades típicas de contratos privados.

\footnotetext{
${ }^{61}$ Nesse sentido, DINIZ, Maria Helena. Tratado teórico e prático dos contratos. 5. ed. São Paulo: Saraiva, 2003. v. 5, p. 431; e FIGUEIREDO, Lúcia Valle. Extinção dos contratos administrativos. São Paulo: Ed. Revista dos Tribunais, 1986. p. 19.
} 
Tais constatações decorrem do fato já destacado acima de que a noção de contrato pertence à Teoria Geral do Direito. Assim, natural que os dois "gêneros" de contratos da Administração Pública apresentem sempre alguns traços em comum (e que é justamente o que os faz pertencer à mesma "espécie"). Por conseguinte, a redação do caput do art. 54 da Lei Federal de Licitações e Contratos Administrativos (Lei Federal n. ${ }^{o}$ 8.666/1993) não poderia ser mais correta no tocante à expressa referência às regras de regência dos contratos celebrados pela Administração Pública ${ }^{62}$ : (i) suas próprias cláusulas; (ii) preceitos de direito público; (iii) princípios da teoria geral dos contratos; e (iv) disposições de direito privado.

Mesmo diante desta realidade de mescilânea entre direito público e privado em todos os contratos, mantemos a classificação dos contratos da Administração Pública em dois gêneros, modalidades ou categorias distintas, pois acreditamos haver diferenças entre elas que permitem traçar uma linha entre elas, não só para melhor estudar as características de cada um desses "grupos”, como também para fins de organização analítica.

Nesse contexto, Marçal Justen Filho assinala:

\begin{abstract}
"O argumento fundamental a favor da distinção entre diferentes espécies de contratos administrativos reside, portanto, na diversidade do regime jurídico aplicável. (...) É necessário efetivar a distinção entre as diferentes espécies de contratos administrativos porque inúmeras regras não são uniformemente aplicáveis a todas elas. $O$ regime jurídico característico dos contratos administrativos propriamente ditos não é integralmente aplicável aos contratos privados da Administração Pública. Quanto a esses, produz-se um regime jurídico especial, que conjuga ora os postulados originais do Direito Privado, ora as regras do Direito Público" ${ }^{\text {63 }}$.
\end{abstract}

Entretanto, em nossa opinião a primordial diferença entre as duas modalidades de contratos da Administração Pública surge em momento anterior às regras aplicáveis a cada uma delas, residindo, na verdade, no envolvimento direto ou não de interesse público. É a presença de interesse público evidente no contrato celebrado pela Administração Pública que resultará na decisão acerca do regime jurídico primordial.

\footnotetext{
${ }^{62}$ Que o legislador chama genericamente de "contratos administrativos", causando certa confusão entre os intérpretes, o que será melhor analisado mais adiante.

${ }^{63}$ JUSTEN FILHO, Marçal. Teoria geral das concessões de serviço público, cit., p. 158, destacamos.
} 
Além disso, não se pode deixar de mencionar que diversos critérios são apontados pela doutrina, legislação e jurisprudência para apontar as diferenças entre as duas modalidades de contratos da Administração Pública, cabendo ao intérprete escolher o(s) que lhe permita(m) atingir o resultado mais preciso possível.

Estes aspectos relevantes ao tema proposto serão mais detalhadamente analisados ao longo deste trabalho.

\section{Das espécies de contratos da Administração Pública}

Segundo a terceira corrente doutrinária mencionada acima, que aceita a existência de contratos da Administração Pública, compõem o gênero "Contratos da Administração Pública" (contratos administrativos "lato sensu") as seguintes espécies:

a) contratos de direito privado (contratos civis) da Administracão: regidos predominantemente pelo direito privado, principalmente no tocante ao conteúdo e aos efeitos. Como exemplo, pode-se citar a compra e venda de um imóvel, a locação de uma casa para instalar uma repartição pública, os contratos de seguro, contratação de serviço suporte de informática (ou de qualquer outro bem ou serviço destinado ao funcionamento cotidiano dos integrantes da Administração Pública enquanto pessoas jurídics), a doação, o comodato e até mesmo a contratação de obra artística ${ }^{64}$.

b) contratos administrativos: regidos prioritariamente pelo direito público (e, mais especificamente, pelo direito administrativo), ainda assim é admitida a aplicação supletiva de normas privadas compatíveis com a índole pública do instituto. São exemplos a concessão de serviço público, a concessão de uso de bem público e o contrato de obra pública.

\footnotetext{
${ }^{64}$ Georges Péquignot (PÉQUIGNOT, Georges. op. cit., p. 13 e ss) dividia os contratos privados da Administração Pública entre contratos privados por determinação legal e contratos privados por suas próprias características. Os contratos privados por determinação legal seriam: (i) contratos para serviço militar; (ii) contratos para admissào de pessoas não indigentes em hospitais; (iii) contratos para recebimento de tributos municipais; (iv) contratos contratos de alguma modalidade claramente especificada pelo Código Civil ou pelo Código Comercial (dentre os quais enumera os contratos de compra e venda, locação, comerciais, de direito marítimo e de trabalho); e (v) contratos que tenham por objeto o domínio privado.
} 
Percebe-se que tais contratos diferem entre si quanto à disciplina do vínculo estabelecido. Entretanto, ambos seriam disciplinados pelo direito administrativo quanto às condições e formalidades para estipulação e aprovação.

Nesse contexto, após assinalar que existem contratos da Administração Pública, ora sob maior influxo de regras de direito público, ora de direito privado, Lúcia Valle Figueiredo destaca que, no seu entendimento, no direito brasileiro não haveria grande importância em separar contratos administrativos e contratos privados da Administração, pois todos vão se submeter à única jurisdição estabelecida no ordenamento jurídico pátrio pelo art. $5^{\circ}$, XXXV da Constituição Federal (princípio da unicidade jurisdicional).

É dizer que no entendimento expressado por referida Autora, como o Brasil - ao contrário da França, grande influenciadora do direito administrativo pátrio - não goza de dualidade de jurisdição, e sim de jurisdição una, quaisquer problemas, conflitos e discussões existentes nos contratos da Administração Pública serão efetivamente resolvidos perante o Poder Judiciário ${ }^{65}$. Diante de tal constatação, ainda segundo referida Autora, a diferenciação entre contratos privados/civis da Administração e contratos administrativos não teria importância prática, restringindo-se sua aplicação ao campo meramente doutrinário ${ }^{66}$.

Não é este, obviamente, o nosso entendimento (até porque, de outra parte, o presente trabalho se mostraria em grande parte desnecessário). Independentemente de qual será o órgão responsável pela análise de pendências, discussões e dúvidas acerca de um contrato, certo é que delimitar qual o regime jurídico que determina a atuação da Administração Pública e preside a interpretação do instrumento em questão é primordial para guiar a atuação do agente público e verificar a legalidade de sua atuação e assim possibilitar, inclusive, coibir a atuação irregular.

Mais do que diferenciar as modalidades de contratos da Administração Pública, importa realmente verificar quais partes de um contrato se submetem ao direito privado e

\footnotetext{
${ }^{65}$ FIGUEIREDO, Lúcia Valle. Curso de direito administrativo, cit., p. 497.

${ }^{66}$ Eduardo García de Enterría e Tomas-Ramon Fernandes acreditam que as razões desse sistema de distribuição de competências jurisdicionais são puramente pragmáticas, e, ainda, que afirmam que é o entendimento da doutrina que, mesmo sendo de natureza civil, determinados contratos da Administração, como os de obras e serviços públicos, devem ser apreciados pelos Tribunais contencioso-administrativos por motivo prático, uma vez que estes Tribunais são mais céleres e estão mais habituados às particularidades do funcionamento da Administração Pública (GARCÍA DE ENTERRÍA, Eduardo; RAMÓN FERNÁNDEZ, Tomás. Curso de derecho administrativo. 1. ed. com notas de Agustín Gordillo. Buenos Aires: La Ley, 2006. p. 710-711).
} 
quais partes são regidas pelo direito público. Não obstante se adote no presente trabalho as terminologias mais comuns na doutrina e jurisprudência para se referir às duas modalidades, certo é que na maior parte dos contratos da Administração Pública não há uma aplicação estanque de um ou de outro regime jurídico. Tanto nos casos de contratos administrativos há, na quase totalidade dos casos, regras de direito privado que devem ser aplicado, quanto há, nos casos de contratos ditos "privados" da Administração Pública regras mandatórias de direito público. Esta é a razão de alguns autores adotarem, nos casos de contratos privados da Administração Pública, a denominação de "contratos semipúblicos",67 ou "contratos administrativos de figuração privada"68.

O tema escolhido para o presente estudo possui conseqüências diretas no cotidiano do ente particular que deseja celebrar ou já celebrou contrato com a Administração Pública, porquanto versa justamente sobre a possibilidade de utilização de regras típicas do direito privado em tais instrumentos, dentre as quais se pode destacar como as que mais atraem a atenção dos particulares: a possibilidade de adoção de métodos alternativos de solução de controvérsias, índices alternativos de reajuste, novas possibilidades de garantias ${ }^{69}$.

A relevância deste estudo para ambas as partes do contrato é bem evidenciada por Maria Sylvia Zanella Di Pietro:

\begin{abstract}
"Costuma-se dizer que, nos contratos de direito privado, a Administração se nivela ao particular, caracterizando-se a relação jurídica pelo traço da horizontalidade e que, nos contratos administrativos, a Administração age como poder público, com todo o seu poder de império sobre o particular, caracterizando-se a relação jurídica pelo traço da verticalidade." ${ }^{, 0}$
\end{abstract}

Portanto, determinar qual o regime jurídico aplicável ao instrumento contratual pode vir a significar, por conseqüência, determinar a posição das partes, quer para efeitos de negociação, quer para efeitos de resolução/intermediação de conflitos, ou, ainda, para controle da Administração Pública.

\footnotetext{
${ }^{67}$ SUNDFELD, Carlos Ari. op. cit., p. 199 e ss; BORGES, Alice Gonzalez. A administração pública como locatária. Revista de Direito Administrativo, Rio de Janeiro, n. 201, p. 71-87, p. 233, jul./set. 1995; e MEIRELLES, Hely Lopes. Direito administrativo brasileiro. 18. ed. São Paulo: Malheiros Ed., 1998. p. 194-196.

${ }^{68}$ MUKAI, Toshio. Contratos públicos. Rio de Janeiro: Forense Universitária, 1995. p. 24-25.

${ }^{69} \mathrm{O}$ setor privado costuma destacar que a possibilidade de maior adoção de regras de direito privado acaba por trazer maior eficiência e atratividade aos negócios jurídicos celebrados com a Administração Pública.

${ }^{70}$ DI PIETRO, Maria Sylvia Zanella Da aplicação do direito privado no direito administrativo, cit., p. 167.
} 
A identificação do contrato como administrativo ou civil pode ter duas aplicações, cada uma delas realizada em momento distinto do agir administrativo e voltada a uma função específica: enquanto a análise do contrato que ainda não foi celebrado se volta à possibilidade de redação correta do instrumento e deve, a nosso ver, verificar qual o interesse envolvido na contratação, a outra, destinada à verificação do regime jurídico regrador de um contrato já celebrado, se mostra útil àqueles que enfrentam as tarefas de interpretação e controle da Administração Pública (seja o controle interno/autocontrole, seja o controle externo, realizado pelo Ministério Público, Tribunal de Contas, Conselho Nacional de Justiça e/ou Poder Judiciário).

Assim, a análise do tema proposto poderá servir, em grande parte, de guia de ação para a Administração Pública na elaboração dos contratos a serem celebrados, pois evidenciará em que medida o direito privado pode ser utilizado em sua atuação, sem com isso prejudicar o regime jurídico administrativo. Como se sabe, os anseios dos administrados que possuem potencial interesse em projetos de infraestrutura (que demandam investimentos vultosos e têm retorno apenas a longo prazo), por exemplo, anseiam por celebrar contratos que envolvam a menor quantidade de riscos possíveis, com os instrumentos mais eficientes. Por isso, tendem a ver com bons olhos a diminuição da quantidade de áleas administrativas e o emprego de ferramentas características do setor privado, como a oferta de garantias especiais, o uso da arbitragem, a adoção de índices específicos de indexação etc.

O tema proposto também servirá à atividade de controle da Administração Pública, quer pela via administrativa (autocontrole), quer pelo Poder Judiciário.

Trata-se de tema com abordagem ainda precária dentre os doutrinadores pátrios, o que, em conjunto com a relevância do assunto, demonstra a pertinência da abordagem proposta. Muito embora os autores brasileiros já tenham, em grande parte, evidenciado a qual das três correntes doutrinárias se filiam, o meio jurídico ainda carece de análise que evidencie quais os limites para o Direito Privado influenciar a celebração de contratos entre Administração Pública e administrados.

Sempre pertinente, Maria Sylvia Zanella Di Pietro assinala que a diferenciação entre contratos administrativos e contratos privados da Administração Pública possui relevância justamente no tocante ao regime jurídico aplicável, pois, como observado acima, 
em um (contrato administrativo) o regime jurídico é predominantemente de direito público, levando à interpretação em consonância com os princípios característicos de tal ramo do direito, enquanto em outro (contratos privados da Administração) "aplica-se o direito privado em tudo aquilo que não for expressamente derrogado por normas de direito público ${ }^{71}$.

É interessante, nesse ponto, destacar o que leciona o Prof. Carlos Ari Sundfeld sobre o assunto ora debatido. Para não fugir à praxe terminológica consagrada pela doutrina, tal autor chama de "contratos administrativos em sentido estrito" os "vínculos onde existam as prerrogativas da Administração, ficando os demais (que a doutrina inadequadamente chama de contratos privados da Administração) enquadrados na categoria dos "contratos administrativos em sentido amplo",72.

\section{Critérios de diferenciação entre modalidades de contratos da Administração Pública}

Antes que se possa iniciar a tarefa de verificar as diferenças entre contratos privados da Administração Pública, pé necessário delimitar o universo dos contratos da Administração Pública. Para isso, Maria João Estorninho ${ }^{73}$ apresenta um processo. Para determinar o universo dos contratos da Administração Pública (que, seguindo a

\footnotetext{
${ }^{71}$ DI PIETRO, Maria Sylvia Zanella Da aplicação do direito privado no direito administrativo, cit., p. 175. Diversos são os autores que já se debruçaram sobre a tarefa de estabelecer os critérios de distinção entre o que é público e o que é privado na sociedade, originando diferentes correntes de pensamentos. Muito embora nosso entendimento seja o de que não há uma única forma de distinção entre tais campos do direito e que, portanto, a forma mais eficaz de identificá-las seja a combinação de critérios, pode-se resumir em três ordens distintas os critérios a serem empregados: (i) a natureza jurídica das pessoas envolvidas (critério orgânico); (ii) o teor das normas aplicáveis (critério material) e (iii) a natureza das relações jurídicas (critério formal). A mesma Maria Sylvia Zanella Di Pietro faz diferenciação entre o direito privado e o direito público que é bastante interessante ao tema, pode evidenciar as conseqüências da utilização de cada regime no âmbito dos contratos: "pode-se concluir que o direito público, composto por normas prevalentemente imperativas, tem por objeto a proteção predominante do interesse coletivo e a disciplina de relações que, caracterizadas pela verticalidade, têm por sujeito as pessoas jurídicas públicas ou as pessoas físicas ou jurídicas que agem em seu nome, numa posição de supremacia sobre as demais pessoas, em decorrência da parcela de poder público de que estão investidas. O direito privado, ao contrário, composto por normas prevalentemente facultativas, tem por objeto a proteção predominante do interesse individual e as relações que regula, caracterizadas pela horizontalidade, têm por sujeito pessoas físicas ou jurídicas, públicas ou privadas, em situação de igualdade" (DI PIETRO, Maria Sylvia Zanella. Do direito privado na administração pública. São Paulo: Atlas, 1989. p. 27, destaques no original).

${ }^{72}$ SUNDFELD, Carlos Ari. op. cit., p. 203.

${ }^{73}$ ESTORNINHO, Maria João. Direito europeu dos contratos públicos: um olhar português, cit., p. 309-316.
} 
terminologia adotada pelo Código de Contratos Públicos português, Decreto-Lei n. ${ }^{\circ}$ 18/2008, denomina simplesmente de "contratos públicos", gênero composto pelas espécies “contrato administrativo" e "contrato privado da Administração"), tal Autora demonstra que o processo de distinção deve ser iniciado separando-se dos contratos (i) os atos e os negócios públicos unilaterais e (ii) os acordos e negócios informais, para então "analisar em que medida tais contratos são celebrados por entidades públicas"," verificar que, "do ponto de vista dos meios, os contratos públicos implicam, em regra, a utilização de dinheiros públicos ou de outros meios públicos"75 e que sempre serão "adjudicados mediante um procedimento administrativo pré-contratual" ${ }^{, 76}$ e que, quando aplicável (como no caso português), o controle será exercido por tribunais administrativos ${ }^{77}$. Por fim, o aspecto essencial, igualmente comum a ambas as modalidades de contratos da Administração Pública:

"Para a qualificação de um contrato como contrato público, é decisivo, a meu ver, o critério do interesse, nos termos do qual serão contratos públicos aqueles que visam a prossecução de fins de interesse público ou, em alguma medida, possam afectar a prossecução desses mesmos fins. Isto não significa que não possam existir contratos públicos nos quais se conciliem interesses privados e interesses públicos mas, nesses casos, aquilo que justifica a qualificação como contrato público é precisamente o facto de, dizendo respeito a certas áreas de actividade, em alguma medida o contrato bulir com interesses públicos." ${ }^{\text {,7 }}$

Uma vez delimitado o universo de análise, passa-se ao próximo passo: distinguir os contratos privados da Administração Pública dos contratos administrativos. Há diversas décadas autores de diferentes países vêm se debruçando sobre o tema dos contratos da Administração Pública para procurar uma diretriz, característica ou elemento que possibilitasse criar uma regra-matriz para a identificação dos contratos privados da Administração Pública e sua diferenciação genérica dos contratos regidos pelo direito público. $^{79}$

\footnotetext{
${ }^{74}$ ESTORNINHO, Maria João. Direito europeu dos contratos públicos: um olhar português, cit., p. 316.

${ }^{75}$ Id. Ibid., p. 318.

${ }^{76}$ Id. Ibid., p. 319.

${ }^{77}$ Id. Ibid., p. 320.

${ }^{78}$ Id. Ibid., p. 317.

${ }^{79}$ Segundo Marcelo Rebelo de Sousa e André Salgado de Matos, "desde as origens do conceito de contrato administrativo (supra) que a doutrina busca um critério que permita proceder à sua delimitação em face dos contratos de direito privado celebrados pela administração. Trata-se de um dos problemas mais complexos, e efectivamente mais discutidos, do direito administrativo moderno. (...) Há mais de um século
} 
Inúmeras foram as regras propostas por tais autores, sendo que Maria João Estorninho apresenta uma didática proposta de sistematização de tais critérios:

\section{a) Critérios Substantivos}

$\underline{\text { Sujeitos }}$

Critério da natureza jurídica das partes

$\underline{\text { Fim }}$

Critério do fim de imediata utilidade pública

$\underline{\text { Objeto }}$

Critério do objeto de serviço público

Critério da sujeição

Critério das cláusulas exorbitantes (versão inicial)

Critério misto serviço público/cláusula exorbitante

Critério alemão da "relação jurídica de direito público"

\section{b) Critérios Formais}

\section{$\underline{\text { Regime Jurídico }}$}

Critério da forma e formalidades

Critério do regime jurídico exorbitante

Critério do "ambiente exorbitante"

Critério estatutário

que o problema da descoberta de um critério individualizador do contrato administrativo, designadamente para efeitos de distinção em face dos contratos de direito privado da administração, ocupa a doutrina jusadministrativista (supra); numa estimativa prudente, os critérios até hoje aventados contam-se por várias dezenas." (SOUSA, Marcelo Rebelo de; DE MATOS, André Salgado. Contratos públicos: direito administrativo geral. Lisboa: Dom Quixote, 2008. t. 3, p. 23-24). 
$\underline{\text { Garantia }}$

Critério da jurisdição competente

Esta mesma Autora divide a adoção de tais critérios cronologicamente da seguinte maneira:

$\underline{1^{a} \text { Fase - o início da diferenca (mais simplistas) }}$

Critério da jurisdição competente

Critério da forma e formalidades

$\underline{2^{a} \text { Fase - a substantivização do contrato administrativo (mais elaborados) }}$

Critério da natureza jurídica das partes

Critério do fim de imediata utilidade pública

Critério do objeto de serviço público

Critério da sujeição

Critério das cláusulas exorbitantes

Critério misto cláusula exorbitante/serviço público

$\underline{3^{a} \text { Fase - conformismo e regresso às origens (momento de crise e incerteza) }}$

Critério do regime jurídico exorbitante

Critério do "ambiente exorbitante"

Critério alemão da "relação jurídica de direito público"

Critério estatutário

Ao final de sua análise de cada um destes critérios adotados pela doutrina, referida Autora afirma que "a dificuldade enfrentada pela doutrina, ao longo de perto de cem anos, em encontrar o critério perfeito de autonomização do contrato administrativo resultou, na minha opinião, do facto de esse critério único não passar de um 'mito', insusceptível de 
ser encontrado na realidade,

Marcelo Rebelo de Sousa e André Salgado de Matos destacam que, dentre a enorme diversidade de critérios de distinção que já foram aventados pela doutrina pátria, "os critérios mais significativos, à luz da sua importância histórica ou actual, são o da taxatividade legal, o da natureza dos sujeitos, o das cláusulas de sujeição, o do regime de sujeição, o do direito estatutário, o do objecto, o do ambiente de direito administrativo e o do fim. Nenhum destes critérios se apresenta como integralmente satisfatório do ponto de vista científico." 81

Georges Péquignot ${ }^{82}$, por sua vez, propõe o uso de duas regras simples: sempre que o contrato se referir a serviço público e/ou contiver regras exorbitantes do direito comum, será administrativo ${ }^{83}$. Além disso, o Autor destaca a necessidade de que ao menos uma das partes seja pertencente ao Estado ou que lhe represente ${ }^{84}$ para que o contrato seja administrativo $^{85}$.

${ }^{80}$ ESTORNINHO, Maria João. Réquiem pelo contrato administrativo, cit., p. 183. No Brasil, nesse mesmo sentido, BATISTA JÚNIOR, Onofre Alves. Transações administrativas. São Paulo: Quartier Latin do Brasil, 2007. p. 292; e MOREIRA NETO, Diogo de Figueiredo. op. cit., p. 570.

${ }^{81}$ SOUSA, Marcelo Rebelo de; DE MATOS, André Salgado. op. cit., t. 3, p. 24.

${ }^{82}$ PÉQUIGNOT, Georges. op. cit., p. 6.

${ }^{83}$ Este, contudo, não é um critério satisfatório, eis que o elaborador do contrato precisará saber se determinado contrato é administrativo ou privado para que, em primeiro lugar, lhe insira ou nào cláusulas ditas exorbitantes.

${ }^{84} \mathrm{O}$ que pode ser, por exemplo, um concessionário de serviço público no exercício de função ligada intrinsecamente ao serviço outorgado (como a prerrogativa prevista no art. 31, VI da Lei Federal n. ${ }^{\circ}$ $8.987 / 1995$, de "promover as desapropriações e constituir servidões autorizadas pelo poder concedente, conforme previsto no edital e no contrato"), ou então um concessionário de uso de bem público que, por meio da posse direta de bem público que lhe é outorgada, deve zelar pelo patrimônio público.

${ }^{85}$ É interessante notar que Péquignot, inclusive, cita exemplos de representações do Estado que já haviam, àquela época, sido aceitas pelo Conselho de Estado como aptas a configurar, cojuntamente com os demais critérios, um determinado contrato como sendo administrativo: um estabelecimento público, como uma Câmara de Comércio (Conselho de Estado, 28 de abril de 1950, Sté pour le traitement industriel des produits de l'Océan: Rec. Lebon, p. 239) ou território no além-mar (Cass. Civ. 20 de junho de 1949, Verdin: Recueil Penant, 1951, I, 1, note Luchaire. - Conselho de Estado, 22 de março de 1950. Territoire des Iles de St-Pierre et Miquelon: Recueil Lebon, p. 177). Por outro lado, não constituiriam contratos administrativos, para o Conselho de Estado, aqueles celebrados entre estabelecimentos de interesse público e empresários (Conselho de Estado, 8 de novembro de 1928, Tissot: S. 1930, 3, 62. - 10 de novembro de 1933, Toussaint: Recueil Lebon, p. 1037. -12 de janeiro de 1951, Bompard, Req. n. ${ }^{\circ}$ 79143); aqueles celebrados entre um estabelecimento de utilidade pública (Conselho de Estado, 28 de abril de 1950, Charbonnier: Recueil Lebon, p. 237) ou uma concessionária (Conselho de Estado, 24 de maio de 1938, Burelle: Recueil Lebon, p. 473) e seus empregados; aqueles celebrados entre o vendedor e o adquirente de uma parcela de um loteamento (Conselho de estado, 11 de maio de 1935, Camelin); e nem tampouco os celebrados entre um contratante de servidor público e seus fornecedores (Tribunal de Conflitos, 13 de julho de 1938, Sté de Forclum: Recueil Lebon, p.1003. - Conselho de Estado, 26 de janeiro de 1944, Sté des Ets. Balzer: Recueil Lebon, p. 32). Também ressalta que o Conselho de Estado reconheceu a teoria da aparência para a definição do contrato como administrativo: se alguém foi levado pelas circunstâncias a crer que um ente privado estava agindo, na verdade, por conta de uma pessoa administrativa, tal contrato pode vir a ser 
Assim, também o particular que exerça legitimamente atividade administrativa pode vir a integrar contrato administrativo, como bem assevera Onofre Alves Batista Júnior:

\begin{abstract}
"No contrato administrativo brasileiro, pelo menos um dos contratantes participa na 'qualidade' de Administração Pública, isto é, como pessoa jurídica integrada em um sistema orgânico dotado de regime privativo. Em alguma porção, um dos contratantes age na qualidade de Administração, revestido do que se pode chamar, com as devidas cautelas, de 'poder público', segundo um modo não acessível, pelo menos a princípio, aos sujeitos privados."
\end{abstract}

Devido à pluralidade de critérios que já foram propostos pela doutrina e/ou adotados pela jurisprudência, convém agrupá-los de acordo com o elemento do contrato analisado, resultando em três grandes grupos, quais sejam: (i) critérios que se focam no objeto do contrato, ou seja, naquilo que as cláusulas inseridas visam à regular (se forem elaboradas para regular negócio jurídico característico de direito público, o contrato será público, caso sejam elaboradas para um negócio jurídico típico do direito privado, entào se tratará de contrato privado); (ii) critérios baseados na análise das características do contrato (havendo dispositivos característicos de direito público e/ou prerrogativas públicas, o contrato será público, caso contrário, na ausência de tais características, será privado); e, finalmente, (iii) critérios subjetivos, voltados às partes do contrato (se ao menos uma das partes integrar Administração Pública direta ou indireta ou estiver agindo em clara representação do Poder Público em função passível de delegação, então o contrato será público, caso contrário, será privado $)^{87}$.

Assim, alguns apontam o critério subjetivo ou orgânico como o mais adequado a tal diferenciação: naquelas situações em que a Administração Pública atua com o uso justificável da potestade pública, em situação de privilégio a que é levada pelo fato de atuar como poder público, adotar-se-á o contrato de direito público, enquanto nas situações em que a Administração seja identificada como órgão, pessoa jurídica, deverá ser equalizada a sua condição à do administrado com quem celebra o contrato em questão, adotando-se o

considerado contrato administrativo (Conselho de Estado, 30 de janeiro de 1931, Sté Brossette: D. H. 1931, 185: negócio realizado por um organismo sindical por conta de um Ministro; e Conselho de Estado, 18 de dezembro de 1936, Prade: D. 1938, 3, 70: contrato celebrado por um sindicato de iniciativa considerada como destinada a um serviço público comunal).

${ }^{86}$ BATISTA JÚNIOR, Onofre Alves. op. cit., p. 293.

${ }^{87}$ Nesse sentido ESTORNINHO, Maria João. Direito europeu dos contratos públicos: um olhar português, cit., p. 320 e ss. 
regime de direito privado.

Sobre o assunto, Luís Cabral de Moncada esclarece sua opinião, evidenciando que a adoção do critério orgânico pode levar o intérprete a confusões, pois por vezes haverá contratos celebrados entre particulares em que ao menos um deles estará no exercício de função pública, e neste caso o contrato deveria ser considerado administrativo. Por esta razão, o Autor sugere a adoção de critério que tenha por base a "administratividade do objeto" do contrato ${ }^{88}$ e o conjunto de poderes e deveres das partes:

\begin{abstract}
"Sendo assim está a admitir-se a possibilidade de entes privados celebrarem entre si contratos de natureza administrativa, natureza esta que transparece do seu próprio objecto (que pode ser a execução de fim de interesse público por exemplo). (...)

É por esta razão que nos parece mais correcta a posição que põe em destaque a administratividade do objecto do contrato (e logo do conjunto dos poderes e deveres assumidos pelas partes) em vez de pôr em destaque a administratividade do fim prosseguido, conceito sempre híbrido e politicamente comprometido, em obediência à ideia segundo a qual o decisivo para o critério do contrato administrativo é o conjunto e a índole dos meios de actuação que a lei confere a cada ente, pois é directamente neles que se reflecte o regime de direito público e portanto aquele critério. (...)

Como conclusão, fica admitida a possibilidade de entes privados celebrarem contratos administrativos para o desempenho de tarefas e fins de interesse público (que intervém a modelar por forma especial o conteúdo das prestações) dado que as pessoas colectivas de direito privado em questão podem estar dotadas por lei de poderes de autoridade para mais eficaz desempenho daquelas finalidades." 89
\end{abstract}

No entanto, para nós o critério proposto por Luís Cabral de Moncada é igualmente passível de falhas se adotado isoladamente, eis que muitas vezes as prerrogativas de Poder Público podem não estar devidamente evidenciadas no contrato, o que, todavia, não será impecilho para seu exercício no caso de comprovado envolvimento de interesse público

\footnotetext{
${ }^{88}$ Critério este que é explicado por Onofre Alves Batista Júnior (com a ressalva de que deve ser aplicado juntamente com o critério orgânico) da seguinte maneira: "Se a Administração Pública, ou algum ente que lhe faça as vezes, está presente, o Direito Administrativo brasileiro admite que se apele para o objeto do contrato, pelo menos a título instrumental. Para verificar se ao contrato aplica-se o regime jurídico administrativo, deve-se, também, em uma primeira verificação, atentar para o objeto do contrato para que se possa determinar as normas que se aplicam, isto é, o regime jurídico aplicável. O objeto do contrato deve, portanto, funcionar como elemento de conexão que permita o reconhecimento de um critério de qualificação do contrato administrativo brasileiro."(BATISTA JÚNIOR, Onofre Alves. op. cit., p. 293).

${ }^{89}$ MONCADA, Luís S. Cabral. O problema do critério do contrato administrativo e os novos contratosprograma. In: Estudos de direito público. Coimbra: Coimbra Ed., 2001. p. 42-43.
} 
(ainda que seja verdade que a falta de sua cristalização em cláusula contratual dificultará o seu exercício).

Outro critério passível de adoção é o de análise da natureza do interesse envolvido na celebração do contrato: naqueles casos em que o instrumento contratual encerra interesse público, se adota contrato administrativo. Por sua vez, nas situações em que for possível identificar interesse privado da Administração Pública, sabe-se ser caso de contrato privado.

Poder-se-ia fazer um paralelo com a identificação de interesse público primário e interesse público secundário, inicialmente promovida por Renato Alessi ${ }^{90}$ e no Brasil adotada por Celso Antônio Bandeira de Mello ${ }^{91}$ : quando se tratar de interesse primário, o contrato seria administrativo. Quando, no entanto, se tratar de interesse secundário (aquele identificado como interesse do Poder Público enquanto pessoa jurídica), o contrato a ser adotado é o contrato de Direito Privado.

Também se pode lembrar da diferenciação, tão comentada outrora pela doutrina pátria, entre atos de gestão e atos de império da Administração Pública. Embora tal nomenclatura e divisão tenham caído em desuso na doutrina ${ }^{92}$, os atos de império poderiam ser equiparados às situações em que se adota contratos administrativos (marcados pelas cláusulas de potestade e superioridade pública), enquanto os atos de gestão seriam equivalentes às situações que demandam adoção de contratos privados. Esta é justamente a opinião de Marcello Caetano, que afirma que a expressão atos de gestão correspondem à gestão privada, regida pelo direito privado, enquanto os atos de autoridade (império) se referem à predominância da gestão pública, sob regência do direito público. No entanto, ressalta esse Autor que em nenhum momento deixa a Administração Pública se estar jungida à busca do interesse público, pois "tão pouco o uso de processos de Direito Privado significa que a Administração Pública deixe de gerir interesses colectivos e de

\footnotetext{
${ }^{90}$ Autor este que, neste ponto, nos remete à lições de Carnelutti e Picardi (ALESSI, Renato. op. cit., p. 197).

${ }^{91}$ BANDEIRA DE MELLO, Celso Antônio. Curso de direito administrativo. 25. ed. São Paulo: Malheiros Ed., 2008. p. 65 e ss.

${ }^{92}$ Oswaldo Aranha Bandeira de Mello observa que "afigura-se acertada a conclusão de que o Estado, na gestão de seu patrimônio e dos seus serviço, para alcançar seu fim, de criação e de realização de utilidade pública, exerce poderes de império, isto é, de comando, e, por conseguinte, deve ser abandonada a pretensão de classificar seus atos em de gestào ou de império. Falta utilidade prática nessa divisão e há, mesmo, dificuldade na colocaçào dos atos nesta ou naquela categoria, por apresentarem ambos os aspectos, conforme a face em que sejam considerados e as diferentes fases dos procedimentos administrativos ao levar a efeito a atividade estatal." (BANDEIRA DE MELLO, Oswaldo Aranha. Princípios gerais de direito administrativo. 3. ed., cit., v. 1, p. 484).
} 
realizar portanto uma gestão pública"93.

No entanto, a crítica a tal critério seria a dificuldade representada pelo fato de que um contrato dificilmente envolve um único interesse da Administração Pública, podendo, diversas vezes, identificar-se nele uma pluralidade de interesses, que muitas vezes resulta na presença concomitante de interesses públicos e interesses privados a justificar a celebração do instrumento contratual.

Outro critério passível de utilização para a diferenciação em questão é o objetivo, segundo o qual se adota a análise do objeto do contrato. Caso se trate de atividade característica do Poder Público, o regime jurídico será compatível (direito público). Por outro lado, se o objeto for típico da vida civil, o regime será de direito privado.

Sobre o assunto, leciona Maria Sylvia Zanella Di Pietro:

"Diríamos até que, mais do que o tipo de atividade, o que se considera
essencial para a caracterização do contrato administrativo é a utilização
que resulta diretamente do contrato. Nesses casos, é patente a
desigualdade entre as partes: o particular visa à consecução de seu
interesse individual; a Administração objetiva o atendimento do interesse
geral. Sendo este predominante sobre aquele, a Administração terá que
agir com todo o seu poder de império para assegurar a sua observância, o
que somente é possível sob regime jurídico administrativo.

Ao contrário, quando a Administração celebra contrato cujo objeto apenas indiretamente ou acessoriamente diz respeito ao interesse geral (na medida em que tem repercussão orçamentária, quer do lado da despesa, quer do lado da despesa, quer do lado da receita), ela se submete ou pode submeter-se ao direito privado; por exemplo, para comprar materiais necessários a uma obra ou serviço público, para colocar no seguro os veículos oficiais, para alugar bem imóvel necessário à instalação de repartição pública, enfim, para se equipar dos instrumento necessários para a realização da atividade principal, esta sim regida pelo direito público. $\mathrm{O}$ mesmo ocorre com relação à utilização de bens do domínio privado do Estado (bens dominicais) por terceiros; se a utilização se der para fins de utilidade pública (mercado municipal, por exemplo), o instituto adequado é a concessão de uso, contrato também tipicamente administrativo; se a utilização se der para proveito exclusivo do particular (como residência) e não para exploração de atividade de utilidade pública, o instituto adequado será a locação. Nesses casos, o interesse público é protegido apenas indiretamente, na medida em que, por esse meio, a administração estará explorando adequadamente o patrimônio, para obtenção de renda." 94

\footnotetext{
${ }^{93}$ CAETANO, Marcello. Manual de direito administrativo. 10. ed. Coimbra: Almedina, 1980. t. 1, p. 464.

${ }^{94}$ PIETRO, Maria Sylvia Zanella. Da aplicação do direito privado no direito administrativo, cit., p. 177-178. A autora, no entanto, faz a ressalva de que o critério do conteúdo de utilidade pública não é absoluto
} 
Alguns autores falam sobre a utilização da finalidade da contratação como critério diferenciador. No entanto, consideramos não haver diferença entre o objeto e a finalidade da contratação. Além disso, pode-se afirmar que o agir da Administração Pública é (ou, pelo menos, deveria ser, pois de outra forma se trata de desvio de poder) sempre guiado pela finalidade pública.

Já houve quem defendesse, também, a adoção do procedimento de contratação como critério. Todavia, o procedimento básico para contratação segue sempre as mesmas regras obrigatórias toda vez que a Administração Pública for parte de contrato, no tocante à licitação, motivação, publicidade, pagamento, dentro outros, havendo as exceções à regra, que são as hipóteses de dispensa e inexibilidade de licitação previstas na Lei Federal n. ${ }^{\circ}$ 8.666/1993 e acatadas pela jurisprudência. Este, portanto, em nossa opinião, não é critério válido.

A presença de cláusula exorbitantes do direito comum no contrato, característica freqüente nos contratos de direito público, tampouco não nos parece ser um critério válido para a diferenciação ora abordada, pois sua admissão como critério definidor do regime jurídico aplicável resultaria em verdadeira tautologia desprovida de função na fase da ação que antecede a celebração do contrato. Além disso, ao se utilizar este critério, seria necessário admitir que a eventual inserção errônea de tais cláusulas em um determinado instrumento teria o condão de modificar a natureza do contrato, o que não corresponde à realidade.

A adoção de critério serve justamente para verificar em quais casos o regime jurídico de Direito Público será aplicável ${ }^{95}$, tarefa de extrema importância (principalmente pragmáticam, pois permite ao Poder Judiciário, por exemplo, verificar como deve ser a análise da contratação) que deve necessariamente ser realizada em dois momentos: inicialmente na redação do instrumento e toda vez em que seja necessário interpretá-lo.

Portanto, de nada adiantaria dizer que contrato administrativo é aquele que possui cláusulas exorbitantes se, em momento anterior, tal contrato não tivesse passado por

(porque, em geral, é a lei que indica os meios para a busca do fim administrativo, nem sempre levando em consideração o tipo de atividade na escolha do regime jurídico) nem suficiente (pois, além do objeto de utilidade pública, há ainda a submissão ao regime jurídico administrativo - visto mais sob o aspecto das prerrogativas do que das sujeições - a diferenciar o contrato administrativo do contrato de direito privado).

${ }^{95}$ Como explicado por Onofore Alves Batista Júnior: "A doutrina brasileira tende, ainda, a apontar que é pela necessária submissão do contrato administrativo a um regime jurídico exorbitante que é possível destacá-lo dos contratos privados da Administração. Parte-se da ideia de que o contrato é administrativo quando estiver sujeito a normas de direito administrativo, isto é, sujeito a regime jurídico administrativo. $O$ fato de estar sujeito a regime jurídico excepcional é que confere à Administração a prerrogativa de impor as chamadas cláusulas exorbitantes." (BATISTA JÚNIOR, Onofre Alves. op. cit., p. 293). 
análise específica que permitisse identificar se aquele contrato deveria possuir tais cláusulas ou não.

Marcelo Rebelo de Sousa e André Salgado de Matos relembram, ainda, que a doutrina já propôs também a adoção de outros critérios, mas todos eles igualmente acabaram por se mostrar insuficientes à determinação inequívoca de caráter científica que se buscava ${ }^{96}$. Nesta situação se enquadram os critérios da taxatividade legal (segundo o qual são administrativos os contratos aqueles que assim forem classificados pela legislação, enquanto os contratos privados serão os demais, mas que enfrenta a dificuldade de a lei não conseguir trazer um rol taxativo e, com isto, deixar que sejam considerados privados contratos que na verdade são administrativos); das cláusulas de sujeição (sendo administrativos os contratos cujo conteúdo atribua poderes de supremacia à parte integrante ou representante da Administração Pública ${ }^{97}$ ); do regime de sujeição (segundo o qual devem ser considerados administrativos os contratos cujo regime se identifique com o direito público ${ }^{98}$ ); do objeto do contrato (sendo administrativos os contratos cujo objeto seja constituir uma relação jurídica administrativa e privados os contratos que se refiram a um relacionamento de natureza privada ${ }^{99}$ ); do fim do contrato (segundo o qual são administrativos os contratos que visem a fim de utilidade pública e privados os que apenas indiretamente se relacionem a tais fins); do grau de intensidade do interesse público prosseguido (contrato administrativo é aquele que coloca o interesse público como prioritário diante de interesses privados que com ele conflitem, enquanto contrato privado é aquele em que o interesse público permanece em paridade com os interesses privados conflitantes ${ }^{100}$ ); e, por fim, do ambiente de direito administrativo (são administrativos aqueles contratos cujos contextos factual e normativo tornem aplicável o direito administrativo, sendo os demais considerados contratos privados ${ }^{101}$ ).

\footnotetext{
${ }^{96}$ SOUSA, Marcelo Rebelo de; DE MATOS, André Salgado. op. cit., t. 3, p. 24-28.

${ }^{97} \mathrm{E}$, neste caso, o critério é objeto de críticas porque parte do pressuposto de que o Estado pode se colocar em posição de supremacia frente aos administrados e porque tal situação não deveria decorrer de cláusulas contratuais, mas sim do regime jurídico aplicável.

${ }^{98} \mathrm{E}$ que se mostra inadequado principalmente porque cria um paradoxo, uma tautologia de pouca utilidade: contrato administrativo é aquele em que prevalesce o direito público e prevalesce o direito público no contrato que é administrativo, mas em quais situações deve o direito público ser inserido no contrato? Trata-se de critério que em muito se assemelha ao do direito estatutário, pois neste é administrativo o contrato em que o direito público é direito ordinário e privado aquele em que o regime privado é a regra.

${ }^{99}$ Critério este que simplesmente substitui o problema de diferenciar as duas modalidades de contratos da Administração Pública pelo de diferenciar as duas modalidades de relações jurídicas.

${ }^{100} \mathrm{~A}$ crítica a este critério é a subjetividade envolvida.

${ }^{101}$ Critério este que, sendo demasiadamente subjetivo, fluido e difuso, não fornecendo resultados suficientemente precisos de sua aplicação.
} 
Do rol claramente extenso de critérios que já foram adotados (e que continua a aumentar), cada Autor escolhe o(s) que acredita fornecer(em) os melhores resultados. Caio Tácito adota os seguintes critérios de caracterização dos contratos administrativos e de diferenciação dos contratos privados (ainda que celebrados pela Administração Pública):

"Primeiramente, atender-se-á ao objeto do contrato que deverá corresponder a um fim de interesse público. Mediante o contrato administrativo cuida-se de satisfazer ao funcionamento dos serviços públicos ou uma finalidade especial de utilidade pública. A tônica do contrato se desloca da simples harmonia de interesses privados para a consecução de um fim de interesse público.

Mas, esse elemento, embora necessário, não é exclusivo. $\mathrm{O}$ contrato administrativo pressupõe, ainda, que a satisfação do interesse público importe em cláusulas especiais, que assegurem à Administração Pública prerrogativas próprias e exorbitantes do direito comum." 102

E o mesmo Autor acrescenta, em outra oportunidade, sua conclusão sobre o tema:

"Em atenção à sua finalidade, submetem-se os contratos administrativos a um princípio de desigualdade entre os contratantes que possibilita à Administração determinada parcela de deliberação que conduz à imposição de sua vontade à do particular contratante, podendo alterar unilateralmente as obrigações do contrato.

É a característica precípua de sua estrutura a que PEQUIGNOT atribuiu a denominação, já agora consagrada, de mutabilidade do contrato administrativo (Théorie Générale du contrat administratif - 1945 - p. 365). $" 103$

Portanto, para Caio Tácito, os contratos privados da Administração Pública são muito semelhantes aos contratos privados "ordinários":

"A Administração Pública poderá pactuar contratos que se regulem pelas normas comuns de direito privado, tendo-se apenas de considerar a capacidade do contratante em função das correspondentes normas normas administrativas, tal como ocorrerá, em geral, com as pessoas jurídicas." 104

${ }^{102}$ TÁCITO, Caio. Contratos administrativos. Revista de Direito Público, São Paulo, v. 18, p. 44-45, out./dez. 1971.

${ }^{103}$ Id. Contrato privado da administração. Exportação de açúcar. In: Temas de direito público: estudos e pareceres. Rio de Janeiro: Renovar, 1997. v. 2, p. 1415.

${ }^{104}$ Id. Ibid., p. 1413. 
E complementa:

\begin{abstract}
"Em suma: se os dois primeiros requisitos de validade (e conseqüentemente da eficácia) dos atos administrativos - a saber, a competência e a finalidade - são sempre necessários e indispensáveis, no que pertine ao requisito de forma somente se verifica igual exigibilidade quando a norma legal a declara essencial.

É a essencialidade de uma forma determinada que vincula a manifestação de vontade do órgão ou agente administrativo.

Assim, quando não estipulada forma essencial, poderá a autoridade optar por aquela que lhe pareça mais adequada à conveniência do ato. Fica o requisito de forma atribuído à discrição administrativa." 105
\end{abstract}

Assim, como se percebe, contrariando a tendência de buscar método de diferenciação entre as modalidades de contratos da Administração Pública, Caio Tácito conclui não haver diferenças relevantes entre os contratos privados da Administração Pública, a não ser aquelas expressamente previstas em lei como indispensáveis, o que, ademais, não soluciona os problemas a serem enfrentados pela Administração Pública, Poder Judiciário, Tribunais de Contas e demais intérpretes de referidos instrumentos.

Diante das dificuldades e falhas apontadas, a busca do critério diferenciador de modalidades é tarefa inacabada, da qual alguns autores, inclusive, já desistiram, rendendose à idéia - a nosso ver simplista - de que tal critério não passa de um mito, o "Eldorado" dos contratos. Assim, como destaca Sérgio Resende de Barros, “da discussão sobre sua existência, o contrato administrativo saiu com especificidade própria, apesar de ainda hoje se disputar sobre suas diferenças específicas, embora se reconheça que existam"106.

Nesse contexto, ao que tudo indica, devido às falhas pontuais de cada uma das metodologias quando aplicadas separadamente, o melhor método de diferenciação seria combinar os critérios expostos acima, de maneira que na área de intersecção deles se encontraria os efetivos contratos administrativos (e, por exclusão, os contratos privados da Administração Pública). O uso combinado de diferentes critérios, cada um deles focado em diferentes aspectos do instrumento analisado, permite conferir uma maior precisão a esta tarefa, atingindo melhores resultados. Em nosso caso, no entanto, temos especial rejeição

\footnotetext{
${ }^{105}$ TÁCITO, Caio. Contrato privado da administração. Exportação de açúcar, cit., p. 1420.

${ }^{106}$ BARROS, Sérgio Resende de. Liberdade e contrato: a crise da licitação. Piracicaba: Ed. Unimep, 1995. p. 62.
} 
pelos critérios tautológicos, que pouco acrescentam ao desafio complexo a ser enfrentado.

Diante dessas dificuldades, Alice Gonzalez Borges, ressalta haver uma tendência de aproximação entre os regimes público e privado de contratação, acentuada no Brasil pelo advento do Código Civil de 2002:

“(...) [V]emos que o novo diploma civil se atualizou, incorporando as mais expressivas conquistas da Constituição de 1988e colocando-se em consonância com seus generosos princípios.

Nesse contexto, um dos pontos mais marcantes dessa nova dimensão se configura na humanização das relações contratuais, consagrando-se o predomínio de regras morais que, antes, constituíam peculiaridades dos contratos administrativos, nem sempre bem aceitas.

Curiosamente, nesse processo, mais uma vez se diluem as fronteiras entre o direito público e o direito privado, e os contratos, na órbita civil, se aproximam cada vez mais dos institutos que até então eram considerados como cláusulas exorbitantes na seara administrativa, tais como as regras pertinentes à manutenção do equilíbrio econômico-financeiro dos contratos administrativos.

Sendo a lei civil, - que, etre nós, disciplina as regras da teoria geral do direito, - fonte subsidiária do regime jurídico especial dos contratos administrativos, não é difícil prever que se anuncia uma verdadeira reviravolta na interpretação desses contratos, bafejada pelos novos princípios.A jurisprudência de nossos tribunais encontrará respaldo cada vez maior, dentro do próprio direito privado, para conter os desvios éticos e verdadeiros abusos do comportamento dos poderes públicos nas relações com seus contratados, com apoio nos amplos desdobramentos dos princípios da boa fé, do abuso de direito e do enriquecimento sem causa, que agora enriquecem nosso Código Civil.,"107

Outra noção, oriunda de enfoque mais prático, pode ser verificada nas lições de Marçal Justen Filho, que, partindo da constatação de que no Brasil vigora entendimento de que não cabe à Administração Pública escolher qual o regime jurídico preponderante dos contratos que celebra, sujeita seus acordos, via de regra, ao direito público. No entanto, a celebração de contratos predominantemente públicos esbarra em limites econômicos (naqueles casos em que a utilização de referido regime jurídico implicaria necessariamente em gastos desnecessários e que não superariam eventuais vantagens a ele inerentes) e em limites jurídicos (nas hipóteses de atividades que não comportem, por natureza, a aplicação do regime jurídico público, de tal maneira que sua aplicação desnaturaria a própria

\footnotetext{
${ }^{107}$ BORGES, Alice Gonzalez. Reflexos do Código Civil nos contratos administrativos. Revista Eletrônica de Direito Administrativo Econômico (REDAE), Salvador, n. 9, fev./abr. 2007. Disponível em: $<$ www.direitodoestado.com.br>. Acesso em: 15 ago. 2010.
} 
atividade, cerceando ilegitimamente o mercado privado, da livre concorrência e de outros valores que recebem proteção constitucional $)^{108}$.

Pois bem. Mesmo diante das dificuldades enfrentadas no processo de diferenciação entre as duas modalidades de contratos da Administração Pùblica e do fato de alguns doutrinadores defenderem haver uma tendência de aproximação entre ambas ${ }^{109}$, para nós sempre haverá diferenças entre os contratos privados da Administração Pública e os contratos administrativos ${ }^{110}$.

\section{Pontos de proximidade entre as modalidades de contratos da Administração Pública}

A Administração Pública se encontra inevitavelmente jungida pelos princípios elencados pela Constituição Federal e legislação correlata.

Assim, por exemplo, jamais poderá a Administração Pública celebrar negócios jurídicos sem a necessária autorização legislativa, posto que se submete à legalidade estrita.

\footnotetext{
${ }^{108}$ JUSTEN FILHO, Marçal. op. cit., p. 486-487.

${ }^{109}$ Que, para alguns Autores, chegaria mesmo a criar um único regime jurídico aplicável a tais contratos.

${ }^{110}$ Como ressaltam Marcelo Rebelo de Sousa e André Salgado de Matos: "impõe-se concluir que, na sua generalidade, os contratos da administração tradicionalmente entendidos como de direito privado devem hoje ser considerados como contratos administrativos, na medida em que correspondem à prossecução de atribuições administrativas através de meios de direito público. (...) A categoria do contrato de direito privado da administração deve ser relegada para um papel marginal, mas é excessivo pretender-se acabar com ela. Assim, são certamente de direito privado os contratos celebrados, na prossecução dos seus fins particulares, por pessoas colectivas sob formas jurídicas privadas que integrem a administração pública (empresas públicas stricto sensu e substitutos administrativos: supra, II), bem como os contratos celebrados, fora da prossecução de atribuições administrativas, por pessoas colectivas de direito público com capacidade jurídica predominantemente de direito privado (entidades públicas empresariais: supra, II), pois não podem considerar-se como de direito público contratos celebrados fora da prossecução de atribuições administrativas (art. $3^{\circ}, 2 \mathrm{CCP}$, a contrario); aqui , a sobrevivência da figura do contrato de direito privado da administração é assegurada pelo reconhecimento da inclusão de pessoas colectivas de direito privado na administração pública em sentido orgânico, bem como pelo reconhecimento de uma capacidade predominantemente de direito privado a determinadas categorias de pessoas colectivas públicas, fenómenos que decorreram em paralelo com o da publicização dos contratos da administração. Também poderão eventualmente considerar-se como de direito privado os contratos da administração que sejam inexeqüíveis ou de execução instantânea, cuja formação seja totalmentedesprocedimentalizada e que cujo objecto não implique a realização de despesa pública [por exemplo, contratos de doação de bens móveis à administração: art. $4^{\circ}, 2$, b), c) CCP]; neste caso, a admissão do carácter não administrativo decorrerá, não da circunstância de os contratos não prosseguirem atribuições administrativas, mas da ausência de espaço para uma densa regulação jurídico-administrativa, que se resume à fixação da competência em sentido subjectivo e do fim de interesse público a prosseguir (supra)." (SOUSA, Marcelo Rebelo de; DE MATOS, André Salgado. op. cit., t. 3, p. 40-41, destacamos).
} 
Tampouco está autorizada a agir em contrariedade ao interesse público. É o que observam Marcelo Rebelo de Sousa e André Salgado de Matos:

\begin{abstract}
"Todos os contratos da administração prosseguem, com maior ou menor grau de intensidade, o interesse público, em termos tais que, em princípio, este deve poder prevalecer sobre os interessses privados com ele conflituantes. Também em conseqüência disto, todos os contratos da administração estão sujeitos ao direito administrativo; e, mesmo quando é menos extensa, esta sujeição envolve geralmente a aplicação de um regime de direito administrativo de densidade outrora impensável quanto aos contratos ditos de direito privado da administração, designadamente no que toca à procedimentalização da formação do contrato e à susceptibilidade de exercício dos poderes administrativos de modificação e rescisão unilateral nos contratos de execução continuada."111
\end{abstract}

Sempre haverá, portanto, em qualquer contrato da Administração Pública, uma constante zona de convivência entre a observância aos princípios da legalidade estrita e da supremacia do interesse público.

Mesmo nos casos de atuação administrativa enquanto pessoa jurídica primariamente sujeita ao direito civil, jamais poderá o Poder Público deixar de observar estes dois princípios ${ }^{112}$. Entendimento contrário a este conduziria à possibilidade - de todo irregular - de que aqueles investidos no mandato público "manipulassem" a busca do que mais lhe convém, ora adotando o regime privado para escapar à observância dos princípios do art. 37 da Constituição Federal, ora agindo sob o manto do direito público. Isso porque a obrigatoriedade da observância aos princípios de direito administrativo decorre da natureza jurídica da Administração Pública e dos termos do mandato outorgado aos administradores quando constituídos, delimitado à atuação em benefício da sociedade, fatores estes que não se alteram de acordo com o regime de atuação administrativa.

Esse traço comum entre as duas modalidades de contratos da Administração Pública as aproxima, ainda que em última instância (pois casos haverá em que a atuação

\footnotetext{
${ }^{111}$ SOUSA, Marcelo Rebelo de; DE MATOS, André Salgado. op. cit., t. 3, p. 39.

${ }^{112}$ Seabra Fagundes afirma que "nunca a atividade [da Administração Pública] pode ser perfeitamente assemelhada à do indivíduo, quer na forma por ue se exerce, quer na sua finalidade. Ainda quando ao revestir o caráter da chamada atividade de gestão" (FAGUNDES, Miguel Seabra. O controle dos atos administrativos pelo Poder Judiciário. 6. ed. São Paulo: Saraiva, 1984. p. 155-156). Especificamente sobre a necessidade de observância do interesse público, Maria João Estorninho afirma que o interesse público não pode nem mesmo ser utilizado como elemento caracterizador do Direito Administrativo, pois mesmo em sua atuação privada a Administração Pública está jungida à sua busca (ESTORNINHO, Maria João. A fuga para o direito privado. Coimbra: Almedina, 1999. p. 168).
} 
administrativa não contrariará nenhum destes princípios e, então, será regida pelo direito privado), mas não as torna idênticas nem tampouco deve ser tratado como se um único regime jurídico fosse aplicável a ambas as modalidades.

Parte da doutrina acredita que atualmente ocorre um movimento de aproximação entre os contratos privados da Administração Pública e os contratos administrativos, com o que concordamos. Todavia, rejeitamos a idéia de que o crescimento das semelhanças entre estas duas modalidades seja tamanho a ponto de criar um regime jurídico único ${ }^{113}$. A dosagem de direito privado e de direito público em uma e em outra modalidade continua a ser diferente, havendo em uma um envolvimento direto de interesse público como regra (contratos administrativos), enquanto na outra o interesse público, ao menos em um primeiro momento, não aparece, havendo, na verdade, a imediata satisfação de uma necessidade da Administração Pública enquanto pessoa jurídica.

Se há formas defesas de atuação administrativa colocadas de maneira geral, certo é que haverá situações em que a Administração Pública terá o dever de agir ou que sua atuação estará vedada, quer em caso de contrato administrativo, quer em caso de contrato privado.

Nas palavras de Lafayette Pondé:

"É certo que o Estado pode participar de situações jurídicas reguladas pelo direito privado. Ainda aí, porém, sua vontade é formada e declarada conforme um regime de direito público; e a finalidade do seu ato é um objetivo de interesse público, porque este é uma constante, que domina toda a atuação do Estado. A competência do órgão agente, as condições jurídicas do exercício desta competência, a especialidade mesma da entidade pública, a forma de manifestação e os requisitos de elaboração daquela vontade, obedecem à regulação do direito público. Os efeitos jurídicos, estes é que se identificam com os efeitos das atividades privadas dos indivíduos, isto é, derivam do mesmo regime do direito privado, a que, nesse caso, mabas as atuações se submetem. Mas, ainda aí, a atividade do Estado é uma atividade pública, e sua vontade é sempre uma vontade de direito público, isto é, formada e expressa por um

\footnotetext{
${ }^{113}$ A respeito da defesa de um regime jurídico único contemporâneo para todos os contratos da Administração Pública, é emblemática a posição de Onofre Alves Batista Júnior: "Em síntese, existe um movimento convergente, por meio do qual se pode reconhecer que nem o contrato administrativo é tão exorbitante, tampouco os contratos privados da Administração são exatamente iguais aos contratos celebrados entre particulares, o que reflete, assim, uma patente aproximação entre todos os contratos da Administração." (BATISTA JÚNIOR, Onofre Alves. op. cit., p. 292). Embora concordemos com a premissa (nem os contratos administrativos são inteiramente públicos, nem os contratos privados da Administração idênticos aos contratos civis ordinários), discordamos da conclusão (criação de um regime jurídico único aplicável às duas modalidades de contratos da Administração Pública).
} 
processo de direito público, ainda que, para produzir os efeitos de direito privado, deva submeter-se à regulação deste." 114

Esta opinião é compartilhada por Maria Sylvia Zanella Di Pietro, que propõe a sistematização dos contratos da Administração Pública em três modalidades:

“(...) [O]s regidos unicamente pelo direito administrativo, sem paralelo no direito privado; os que, embora tenham o equivalente no direito civil, constituem uma ramificação da categoria jurídica definida pela teoria geral do Direito; e, finalmente, os que são regidos pelo direito privado, com derrogações maiores ou menores impostas pelo direito público. Nas duas primeiras hipóteses, aplica-se o regime administrativo, na última, o regime de direito privado com as derrogações impostas pelo direito público, hipótese em que alguns preferem falar em direito misto. São muito poucas, se não raras, as hipóteses de aplicação pura do direito privado." 115

As diferenças advindas de referidos regimes jurídicos residem, para a Autora, no fato de que “(...) enquanto, nas relações de direito público, os privilégios e prerrogativas se presumem, independentemente de previsão legal, porque são inerentes à autoridade de que se reveste a Administração Pública, no exercício de funções consideradas essenciais; nas relações de direito privado o que se presume, no silêncio da lei, é a igualdade de posição; os desvios ao direito comum são apenas os expressamente previstos na lei."

Parece-nos, portanto, que mesmo naquelas situações em que o contrato da Administração Pública é regido majoritariamente pelo direito privado, haverá situações relacionadas com o objeto contratual ou não - que conclamarão à utilização de prerrogativas públicas alheias ao regime de direito privado $^{117}$. Nesse sentido, Maria Sylvia Zanella Di Pietro bem assevera:

\footnotetext{
${ }^{114}$ PONDÉ, Lafayette. A vontade privada na formação ou na eficácia do ato administrativo. Revista de Direito Administrativo, Rio de Janeiro, n. 63, p. 17, jan./mar. 1961.

${ }^{115}$ DI PIETRO, Maria Sylvia Zanella. Do direito privado na administração pública, cit., p. 92.

${ }^{116}$ Id. Ibid., p. 9.

${ }^{117}$ Como defende Rafael Véras de Freitas, "em determinadas situações, a indisponibilidade do interesse público faz com que os interesses primários se sobreponham aos interesses dos particulares, especialmente em contratos administrativos." (FREITAS, Rafael Véras de. A concessão de florestas e o desenvolvimento sustentável. Revista de Direito Público da Economia - RDPE, Belo Horizonte, ano 7, n. 26, p. 130, abr./jun. 2009).
} 
"Pode-se acabar com a figura do contrato administrativo, como querem alguns. Mas não há como acabar com as prerrogativas que a Administração Pública exerce sobre os particulares, mesmo que utilizados os modelos do direito privado. A razão é muito simples: a posição do particular não pode ser igualada à da Administração Pública, porque esta personifica o poder do Estado." 118

Esta é uma constatação de grande relevância, pois traz consigo a potencialidade de afetar contratos que algum consideram ser totalmente imunes às prerrogativas características da Administração Pública.

Há, todavia, posições divergentes na doutrina, como, por exemplo, a de Vladimir da Rocha França, para quem "nem todos os contratos de direito privado da Administração admitem cláusulas exorbitantes. Os contratos civis, mercantis e de trabalho firmados pelas empresas públicas e sociedades de economia mista não devem prever a essas entidades prerrogativas estranhas àquelas previstas para os particulares em geral" 119 .

Como já foi destacado, não concordamos com esta última corrente doutrinária, pois defendemos não haver restrição ao exercício legítimo e motivado de prerrogativas pela Administração Pública que tenham como única finalidade a preservação do interesse público $^{120}$. Os direitos dos contratantes privados, que se resumem à rentabilidade pecuniária do contrato, estarão sempre a salvo com a manutenção obrigatória do equilíbrio econômico-financeiro da relação ${ }^{121}$.

Marçal Justen Filho ${ }^{122}$ defende que naqueles casos em que a Administração Pública

\footnotetext{
${ }^{118}$ DI PIETRO, Maria Sylvia Zanella. Ainda existem os chamados contratos administrativos? , cit., p. 409.

${ }^{119}$ FRANÇA, Vladimir da Rocha. Conceito de contrato administrativo. Revista Eletrônica de Direito Administrativo Econômico, Salvador, n. 7, ago./out. 2006. Disponível em: $<$ http://www.direitodoestado.com.br>. Acesso em: 13 nov. 2009. p. 10.

${ }^{120}$ Conforme defende Alice Gonzalez Borges, ao abordar o tema dos contratos de locação da Administração Pública: "Aliás, a propósito, lembre-se que por isso mesmo teve a Lei 8.666/93 a salutar cautela de exigir, no caso de rescisão contratual 'por motivo de interesse público' (art. 78, XII), e no da revogação da licitação por 'razões de interesse público' (art. 49), que a existência de tal interesse público seja devidamente justificada, demonstrada sua pertinência, e mediante parecer jurídico vinculante." (BORGES, Alice Gonzalez. Supremacia do interesse público: desconstrução ou reconstrução? Revista Diálogo Jurídico, Salvador, n. 15, jan./mar. 2007. Disponível em: <www.direitopublico.com.br>. Acesso em: 25 jul. 2010).

${ }^{121}$ Nesse sentido, MARTINS, Ricardo Marcondes. Contratos administrativos. Revista Eletrônica de Direito do Estado - REDE, Salvador, n. 17, p. 33-38, jan./mar. 2009. Disponível em: $<$ www.direitodestado.com.br/rede.asp>. Acesso em: 13 mar. 2010.

${ }^{122}$ JUSTEN FILHO, Marçal. Comentários à Lei de Licitações e Contratos Administrativos. 9. ed. São Paulo: Dialética, 2002. p. 543-544.
} 
fizer uso de suas prerrogativas haverá, na verdade, duas possibilidades para a(s) parte(s) privada(s), dentre as quais o particular poderia escolher: aceitar o ocorrido, desde que acompanhado da readequação da relação financeira ${ }^{123}$, ou extinguir o vínculo contratual. Para nós, no entanto, o particular não tem a seu dispor, via de regra, a opção de extinguir o vínculo contratual nesta hipótese, pois se partindo do pressuposto de que a Administração Pública exerceu uma prerrogativa pública, há interesse público em jogo (que deve ser devidamente demonstrado), que não pode ser ameaçado pela extinção prematura do contrato.

É o caso, por exemplo, de descumprimento contratual causado por uma situação específica da Administração Pública, em que esta poderá fazer valer prerrogativas públicas em amabas as modalidades de contratos (muito embora a forma de comprovação demandada em cada uma destas modalidades seja distinta $\left.{ }^{124}\right)$. Nesse sentido, no julgamento da Petição n. ${ }^{\circ}$ 1.665-3 ${ }^{125}$, o Ilmo. Ministro Moreira Alves, relator do processo no E. Supremo Tribunal Federal (STF), ao analisar a legalidade de contrato de confissão, promessa de assunção, consolidação e refinanciamento de dívidas assinado pela União Federal e o Estado de Minas Gerais - contrato tipicamente regido pelo direito privado mesmo quando uma das partes é o Poder Público -, consignou que o princípio pacta sunt servanda não é absoluto em qualquer das modalidade de contrato da Administração Pública, quer público ou privado:

"Não há dúvida de que o princípio pacta sunt servanda, quer no campo dos contratos privados, quer no terreno dos contratos públicos, inclusive administrativos, não tem caráter absoluto no direito moderno. No Brasil, doutrina e jurisprudência admitem, embora com cautela principalmente por parte desta, o princípio que vem da antiga cláusula 'rebus sic stantibus' e que modernamente se apresenta em modalidades como a da 'teoria da imprevisão' ou a da 'onerosidade específica', afastando-se, quando ocorrem seus requisitos, a imutabilidade do pactuado nos contratos comutativos de trato sucessivo, para admitir sua resolução ou, às vezes, sua revisão. Civilistas e publicistas salientam que essas teorias só se aplicam a tais contratos quando se verificarem os requisitos assim arrolados por CAIO MARIO DA SILVA PEREIRA ('Instituições de Direito Civil', vol. III, 5. ed., n. 216, p. 141, Forense, Rio de Janeiro, 1981): 'Para que se possa, sob

\footnotetext{
${ }^{123}$ Em nossa opinião, mesmo nos casos de rescisão unilateral do contrato pela Administração Pública o mandamento da manutenção do equilíbrio econômico-financeiro dos contratos torna necessário que se pague uma indenização à(s) parte(s) privada(s).

${ }^{124}$ Pois enquanto no contrato administrativo o interesse público, via de regra, é evidente, no contrato privado é necessário tomar providências adicionais para demonstrá-lo e motivar o ato de exercício da prerrogativa.

${ }^{125}$ In REVISTA de Direito Administrativo, Rio de Janeiro, v. 215, p. 240-245, 1999.
} 
fundamento na teoria da imprevisão, atingir o contrato, é necessário ocorram requisitos de apuração certa: a) vigência de um contrato de execução diferida ou sucessiva; b) alteração radical das condições econômicas objetivas no momento da execução, em confronto com o ambiente objetivo da celebração; c) onerosidade excessiva para um dos contratantes e benefício exagerado para o outro; d) imprevisibilidade daquela modificação'. E HELY LOPES MEIRELLES ('Direito Administrativo Brasileiro', 23. ed., p. 212, Malheiros Editores, São Paulo, 1998) acentua que a teoria da imprevisão 'é a aplicação da velha cláusula 'rebus sic stantibus' aos contratos administrativos, a exemplo do que ocorre nos ajustes privados, a fim de que sua execução se realize sem a ruína do contratado, na superveniência de fatos não cogitados pelas partes, criando ônus excessivo para uma delas, com vantagem desmedida para a outra'." (destacamos)

Dentre outras coisas, o Estado de Minas Gerais naquela ocasião havia alegado:

"De outra parte, os contratos firmados entre os Estados-membros e a
União não configuram contrato administrativo que admite cláusulas
exorbitantes, pois nele não há relação de subordinação entre os
contratantes, mas relação de coordenação, motivo por que esses contratos
se aproximam dos acordos firmados entre países soberanos, onde não se
admite a cobrança coercitiva de débitos"126.

No entanto, quando se trata de contrato da Administração Pública, a relatividade do princípio do pacta sunt servanda é ainda mais peculiar. Voltando ao mesmo acórdão citado acima, o Relator afirma em outra passagem, que naquele caso não se verificavam os requisitos caracterizadores da onerosidade excessiva do Código Civil nem tampouco se caracterizava a onerosidade prevista pelo Código de Defesa do Consumidor (porquanto ausente a hipossuficiência de uma das partes), asseverando que o descumprimento contratual do Estado de Minas Gerais seria justificada pelo estado de necessidade, e, assim, não constituiria ilícito nem mesmo responsabilidade civil extracontratual:

\footnotetext{
${ }^{126}$ Argumento este aceito pelo Relator, que afirmou: "Tendo em vista que se trata de contrato entre duas pessoas jurídicas de direito público interno - a União Federal e o Estado-membro de Minas Gerais - que estão em relação de coordenação e não de subordinação de um em face do outro, e contrato a que, por seu objeto, não se aplicam os princípios e as regras de direito administrativo, enquadra-se ele no que alguns autores (assim, CRETELLA JÚNIOR, 'Tratado de Direito Administrativo', vol. III, p. 16, Forense, Rio-São Paulo, 1967) denominam 'contratos privados da administração' e outros (assim, LÚCIA VALLE FIGUEIREDO, Curso de Direito Administrativo', $2^{a}$ ed., p. 329, Malheiros Editores, São Paulo, 1995), a meu ver com maior razão, designam, em contraposição aos 'contratos administrativos', como contratos da Administração Pública', por terem de observar sob muitos aspectos o regime contratual do direito público, embora se submetam basicamente às normas contratuais do direito privado."
} 


\begin{abstract}
"Por outro lado, o estado de necessidade, quer no direito público, quer no direito privado, não dá margem a resolução de contrato ou a revisão de cláusulas contratuais. E ele circunstancia excludente de ilícito absoluto e, conseqüientemente, de responsabilidade civil extra-contratual, e não de ilícito relativo e como o é o inadimplemento contratual. BIELSA ('Derecho Administrativo', tomo I, 6. ed., n. 23, II, p. 114, La Ley, Buenos Aires, 1964), tratando do estado de necessidade no direito administrativo, salienta: 'No direito administrativo o estado de necessidade, como justificativa do dano causado pelo poder público, determina a isenção de responsabilidade do Estado ou de seus agentes' ('En el derecho administrativo el estado de necessidad, como justificativo Del dano causado por el poder publico, determina la exencion de responsabilidad del Estado o de sus agentes'). No mesmo sentido, CRETELLA JUNIOR (Ob. Cit., vol. VIII, n. 71, p. 103, Forense, Rio-São Paulo, 1970), examinando a responsabilidade extra-contratual do Estado, observa que 'o estado de necessidade é também exclusivo da obrigação de indenizar e, portanto, da responsabilidade, afigurando-se como situação em que predomina o interesse geral sobre o interesse pessoal, conveniência e mesmo direitos individuais' e no Código Civil brasileiro o estado de necessidade está previsto no inciso II e no parágrafo único do artigo 160 como circunstância excludente do ato ilícito absoluto que é definido no artigo 159."
\end{abstract}

A configuração do estado de necessidade do Poder Público como justificativa do descumprimento contratual, contudo, deve ser examinada com extrema cautela, sob pena de ser banalizada. Ademais, não se pode esquecer de que o princípio da "reserva do possível" é utilizado por parte da doutrina como motivador do descumprimento de obrigações (impossibilidade econômica de cumprimento de obrigações) ${ }^{127}$. Estas justificativas, no entanto, carregam consigo o ônus da prova a quem as alega. E a comprovação, em nossa opinião, não pode ser mera alegação de crise, de queda de arrecadação, de déficit fiscal, mas sim de natureza contábil, de cumprimento da Lei de Responsabilidade Fiscal ou de qualquer outra forma de demonstração efetiva da alegação.

\footnotetext{
${ }^{127}$ Canotilho oberva que a doutrina rapidamente aderiu à dogmática do princípio da reserva do possível (Vorbehalt des Möglichen) "para traduzir a ideia de que os direitos sociais só existem quando e enquanto existir dinheiro nos cofres públicos. Um direito social sob 'reserva dos cofres cheios' equivale, na prática, a nenhuma vinculação jurídica. Para atenuar esta desoladora conclusão adianta-se, por vezes, que a única vinculação razoável e possível do Estado em sede de direitos sociais se reconduz à garantia do mínimo social. Segundo alguns autores, porém, esta garantia do mínimo social resulta já do dever indeclinável dos poderes públicos de garantir a dignidade da pessoa humana e não de qualquer densificação jurídicoconstitucional de direitos sociais. Assim, por exemplo, o 'rendimento mínimo garantido' não será a concretização de qualquer direito social (sic) em concreto (direito ao trabalho, direito à saúde, direito à habitação) mas apenas o cumprimento do dever de socialidade imposto pelo respeito da dignidade da pessoa humana e pelo direito ao livre desenvolvimento da personalidade". (CANOTILHO, J. J. Gomes. Direito constitucional e teoria da constituição. 7. ed. Coimbra: Almedina, 2003. p. 481).
} 
Isso porque, como se sabe, há uma presunção de que o objeto do contrato celebrado pela Administração Pública visa, direta (contrato administrativo) ou indiretamente (contrato privado), a consecução de interesse público. Contrario sensu, seu descumprimento parte de presunção de contrariedade ao interesse público envolvido, em benefício de um interesse do próprio órgão público (aquele interesse público denominado "secundário" por Renato Alessi).

Assim, somente a real e comprovada inviabilidade da prestação poderia ser aceita como justificadora de um descumprimento contratual. Ademais, não se pode olvidar que o repetido descumprimento de obrigações contratuais pela Administração Pública depõe contra sua reputação enquanto contratante (reputação esta já demasiadamente afetada pelo moroso pagamento de precatórios).

Nunca é demais ressaltar que a contratação com a Administração Pública é, via de regra, mais onerosa para o particular do que a mera contratação entre dois ou mais entes privados (seja pela necessidade de procedimento licitatório, seja pela demonstração de condições de contratação, limitação da duração dos contratos ou outras). Se a isto somar-se o repetido e desmedido descumprimento contratual, corre-se o risco de esgotar-se a atratividade da contratação junto à Administração Pública, pelo excesso de risco e abuso arbitrário ${ }^{128}$.

Nesse sentido, o Estado de Minas Gerais, naquele caso, apresentou pedido alternativo à suspensão de cláusulas contratuais, solicitando o reconhecimento da presença da excludente de ilicitude consubstanciada no estado de necessidade administrativo, “mediante a comprovação mensal pelo requerente, devidamente atestado pelo Tribunal de Contas do Estado de Minas Gerais, da inequívoca impossibilidade econômico-financeira do Estado, sendo certo que a comprovação deverá ser feita até o dia 28 do mês seguinte”.

Portanto, a Administração Pública não deixará de ser uma pessoa jurídica de direito público apenas porque figura como parte de um contrato regido pelo direito privado, e justamente este fato acarreta (ou pode potencialmente acarretar) peculiaridades ao referido contrato. Mesmo que a regra seja efetivamente colocar a Administração Pública em

\footnotetext{
${ }^{128}$ Alice Gonzalez Borges leciona que deve "o intérprete da lei limitar aquelas preorrogativas ao essencial, não somente por amor à verdade jurídica como, também, por um fator que nos parece muito importante: há um sério perigo que a Administração que celebra tais contratos (semipúblicos, ou de configuração privada, como quer que os denominemos) não encontre particulares que queiram contratar com o Estado aceitando a imposição das aludidas prerrogativas especiais." (BORGES, Alice Gonzalez. A administração pública como locatária, cit., p. 233).
} 
igualdade de condições com a outra parte do contrato, certo é que tal igualdade é contextual ao instrumento celebrado e desde o início pode potencialmente vir a ser alterada, no caso de advento de se verificar um interesse público que leve à rescisão ou alteração do contrato $^{129}$.

No entanto, nossa opinião é a de que, ao fazer valer uma prerrogativa do Poder Público característica do regime de direito público, o contrato é trazido, ainda que parcialmente, para a égide deste regime jurídico também com relação às suas necessárias contrapartidas, que são (i) a manutenção do equilíbrio econômico-financeiro do contrato ${ }^{130}$ e (ii) a possibilidade de, nos casos de alteração do contrato, o particular retirar-se da relação contratual ${ }^{131}$.

Essa atitude parte do reconhecimento da existência de diferenças entre as partes dos contratos: de um lado, particular(es), entes privados; de outro, Estado, figura de direito público. Diante das diferenças entre as partes, cabe utilizar instrumentos de balanceamento que, assim, mantenham os respectivos interesses na contratação e atinjam à pacificação de vontades, que é, afinal de contas, o fim do contrato.

Tal fenômeno é semelhante ao que ocorre em outros campos do direito em que se reconhece a existência de diferenças entre as partes contratantes, como, por exemplo, no direito do consumidor e no direito do trabalho. Em tais campos, a "hipossuficiência" de uma das partes ${ }^{132}$ diante da outra justifica a adoção de prerrogativas específicas, visando ao atingimento de condições suficientes a resguardar os interesses que levaram a parte a

\footnotetext{
${ }^{129}$ Edmir Netto de Araújo afirma que "deve-se, entretanto, lembrar (...) que os princípios da legalidade, da prevalência do interesse público, e mais a titularidade do serviço público pela Administração concedente, impõem a existência de cláusulas de supremacia implícitas, que, mesmo não constando do instrumento formal concessivo, são válidas e operantes, como se expressas estivessem." (ARAÚJO, Edmir Netto de. op. cit., p. 643). Da mesma maneira, um contrato do qual a Administração Pública seja parte sempre traz consigo a potencialidade de, uma vez demonstrada a influência de interesse público, invocar prerrogativa que não esteja expressamente estabelecida no instrumento contratual.

${ }^{130} \mathrm{O}$ marco da preservação de tal equilíbrio é o aresto Compagnie Générale Française de Tramways, de 11 de março de 1910, no qual se discutia o fato de o "Prefeito" (péfet) do Departamento de Bouches-du-Rhône ter determinado à empresa que aumentasse a abrangência de horários de seus serviços para atender adequadamente a demanda crescente da população. Diante de tal determinação, o Conselho de Estado determinou a deadequação da quantia a ser paga pela Administração Pública para a manutenção da "équation financière"/"équivalence honnete des prestations" (conforme LONG, Marceau; WEIL, Prosper; BRAIBANT, Guy; DELVOLVÉ, Pierre; GENEVOIS, Bruno. Les grands arrêts de la jurisprudence administrative. Paris: Dalloz, 1996. p. 128).

${ }^{131}$ Esta segunda prerrogativa do particular só não se faria possível naqueles casos em que a manutenção do vínculo contratual seja imperiosa ao(s) interesse(s) público(s).

${ }^{132}$ Respectivamente o consumidor e o trabalhador.
} 
$\operatorname{contratar}^{133}$.

Este fato demonstra que não necessariamente se deve partir da presunção de equivalência entre as partes para a celebração de um contrato. Na verdade, como o contrato é o instrumento formalizador de um encontro de vontades - e que, assim, tem função pacificadora social -, ele traz consigo ferramentas que implementam o exercício de prerrogativas, não necessariamente equânimes, mas sim bastantes para satisfazer os interesses de cada uma das partes, que assim celebrarão um negócio jurídico.

Ora, a Administração Pública jamais será idêntica a um particular. Por esta razão, a existência de prerrogativas peculiares do Estado perante o particular e deste junto à Administração Pública não são propriamente uma equalização em busca da igualdade, mas sim um balanceamento, com concessões e contrapartidas que levam as partes a um contentamento mútuo expressado com a celebração do contrato.

A respeito da impossibilidade de verdadeira equalização entre particulares e Administração Pública, Maria Sylvia Zanella Di Pietro observa o que segue:

"Pensando especificamente no tema do contrato, verifica-se que
realmente nunca a posição da Administração poderá ser inteiramente
igual à do particular, mesmo nas relações de direito privado: a autonomia
da vontade, de que é dotado o particular, substitui-se, para a
Administração, pelo princípio da legalidade; a liberdade de forma, que
prevalesce nas relações jurídicas entre particulares, dificilmente existe
nas relações jurídicas em que a Administração é parte; além disso, ela
está vinculada a determinados fins, que a obrigam a adotar os meios que
o legislador escolhe como os únicos viáveis para a sua consecução; a
tudo acrescente-se o fato de que ela conserva, mesmo quando se utiliza
do regime de direito privado, certos privilégios que lhe sào concedidos

${ }^{133}$ Sobre o movimento inicial de intervencionismo legislativo sobre o dirigismo contratual para nivelamento entre as partes, José Cretella Júnior observa: "O Código de Napoleão inaugurou a época da oprimazia contratual, em que as relações das partes são concertadas, livre e voluntariamente, sobre tudo aquilo que estiver ao alcance das possibilidades humanas, observando-se o nivelamento das partes e a liberdade dos contratantes, no início, meio e fim do ajuste, a imutabilidade das cláusulas, em quaisquer circunstâncias, a limitação das consequências às partes celebrantes.

Profundas transformações de natureza econômica, ocorridas em épocas posteriores, determinaram o desnivel cada vez maior entre as partes, a ponto de o livre consentimento de antes passar a ser, na maioria dos casos, a simples aceitação, em bloco, sem discussão, do conjunto de cláusulas apresentadas pelo economicamente forte ao economicamente fraco. Para evitar a exploração deste último, pelo primeiro, os poderes públicos ocidentais, representados pelos juizes e pelo poder que administra, principiam a intervir entre as partes, impedindo o desequilíbrio cada vez mais acentuado e assinalando uma uma nova época, bastante característica, na história do direito - a do 'dirigismo contratual', na expressão feliz e consagrada de Josserand. É a fase da publicizaçào do contrato. Vai desaparecendo a autonomia da vontade, predominando agora o princípio informativo salus populi maxima lex esto." (CRETELLA JÚNIOR, José. Direito administrativo comparado, cit., p. 239-240). 
por lei, em razão da pessoa, como o juízo privativo, o processo especial de xecução, a impenhorabilidade de seus bens, os prazos mais dilatados em juízo." 134

Obviamente, não se está a afirmar que, devido à sua natureza jurídica peculiar, a Administração Pública pode estabelecer o ônus que desejar para o particular sob a justificativa de estar exercendo prerrogativa que lhe é inerente. Como leciona Oswaldo Aranha Bandeira de Mello:

"Os dois elementos que presidem o contrato, qual seja, a liberdade na
perfeição do acordo e a autoridade das suas cláusulas, de modo que, uma
vez formado, faz lei entre as partes, pressupõem a existência de
equivalência de prestações de cada uma, tendo em vista seus recíprocos
interesses. Do contrário essa liberdade na sua perfeição será
simplesmente formal, e essa lei entre as partes será injusta, pela situação
desigual a que se sujeitariam.
Conseqüentemente, inspiradas pela eqüidade, como justiça do caso
concreto, duas teorias informam o contrato, como instituto jurídico, ou
seja como acordo de vontades sobre interesses opostos: a da lesão e a da
imprevisão."135

Os encargos decorrentes do fato de se contratar com a Admnistracão Pública são notórios e amplamente conhecidos por todos. Assim, os ônus das peculiaridades decorrentes da participação em certame licitatório, obtenção de certidões, manutenção da regularidade jurídica e fiscal, além das condições subjetivas, assim como a possibilidade de, no advento de interesse público envolvido (lembrando-se que nos casos de contratos privados da Administração Pública, via de regra, em um primeiro momento não há envolvimento imediato de interesse público, mas meramente interesse patrimonial

\footnotetext{
${ }^{134}$ DI PIETRO, Maria Sylvia Zanella. Ainda existem os chamados contratos administrativos?, cit., p. 409.

${ }^{135}$ BANDEIRA DE MELLO, Oswaldo Aranha. Princípios gerais de direito administrativo. 3. ed., cit., v. 1, p. 452-453. A teoria da imprevisão começou a ser aplicada no âmbito dos contratos da Administração Pública com o aresto da Companhia de Gás de Bordeaux, de 24 de março de 1916. O Conselho de Estado francês acompanhou o parecer do "relator"(comissário do governo) do processo, Chardenet, favorável ao pedido da concessionária, que recorria da decisão do governo que havia negado o reajuste das tarifas do serviço, baseada na alta dos custos do carvão, consequência da Primeira Guerra Mundial. Posteriormente, a teoria da imprevisão foi adotada pelo Conselho de Estado em outros processos, consolidando sua aplicabilidade a contratos da Administração Pública. Antes do advento do aresto da Companhia de Gás de Bordeaux, já havia outros precedentes do Conselho de Estado envolvendo discussões sobre componentes da teoria da imprevisão nos contratos da Administração Pública (como, por exemplo, o aresto Labeye, de 3 de fevereiro de 1905, envolvendo concessão de obra pública na cidade de Paris, e o aresto de Aube, de 19 de junho de 1914, em que se discutiu concessão de serviço público à Companhia de Estada de Ferro do Departamento de Aube).
} 
disponível), serem levadas a cabo - proporcionalmente, motivadamente e somente na medida do estritamente necessário - prerrogativas públicas, não podem ser utilizados na tentativa de demonstrar desequilíbrio de encargos entre as partes de contrato da Administracão Pública.

Por outro lado, a necessidade de manutenção do equilíbrio econômico-financeiro dos contratos da Administração Pública é a contrapartida pelas peculiaridades mencionadas acima, visando a manter a atratividade do negócio jurídico para as partes não pertencentes à Administração Pública. E ela poderá surgir tanto nos contratos administrativos (regra) quanto nos contratos privados da Administração Pública (exceção), desde que ativada pelo exercício de prerrogativa pública.

Em vista do quanto exposto acima, é importante que jamais se tire de vista que partes que possuem natureza jurídica distinta podem, de acordo com o caso, utilizar em maior ou menor incidência um determinado regime jurídico em um instrumento com o qual mutuamente concordem, mas suas respectivas naturezas jurídicas e as regras pelas quais elas próprias são regidas não serão modificadas pelo regime preponderante que venham a impregnar o contrato celebrado. Em outras palavras, o regime jurídico da criatura (contrato) não tem o condão de alterar o(s) regime(s) jurídico(s) dos criadores (partes).

\section{Sobre a posição adotada no presente trabalho}

Tendo concluído (i) que a Administração Pública sempre estará inevitavelmente vinculada aos princípios que a regem; e (ii) que raramente haverá um único regime jurídico aplicável à integralidade do contrato, cabe passar-se à análise do que o sistema jurídico estabelece no tocante à celebração de contratos pela Administração Pública, para que então se possa discutir em que situações de contratação vigerá o direito privado e em que situações se aplicará o direito público.

Adotaremos, em consonância com nossa opinião e com a tese recepcionada pelo ordenamento jurídico pátrio, a terceira corrente demonstrada anteriormente, segundo a qual os contratos privados da Administração seriam aqueles em que predomina a vigência do 
regime jurídico privado para a sua condução ${ }^{136}$.

Os contratos privados da Administração Pública assemelham-se em grande parte àqueles celebrados entre duas ou mais partes classificadas como entes privados. No cotidiano são regidos pelo direito privado e apenas em situações excepcionais o direito público se aplica. Tal aplicação pontual se deve, na verdade, ao fato de ao menos uma das partes ser uma pessoa jurídica de direito público.

Sobre esse fato, Eduardo García de Enterría e Tomás-Ramón Fernández lecionam:

"Pois bem, deve-se advertir que no caso concreto dos contratos da Administração a distinção entre os de caráter privado não remete a regimes jurídicos irredutivelmente diferentes, mas sim em boa parte próximos. Deve-se notar também que tais regimes não são unitários e compactos, ou seja, não há um regime jurídico apenas para os contratos administrativos e outro para os contratos privados, mas sim vários regimes distintos de cada lado da linha divisória. Dito de outro modo, a distinção de regimes jurídicos se dá mais por séries ou tipos de contratos individualmente considerados do que por sua qualificação genérica como privados ou administrativos." 137

“(...) A qualificação de um contrato da Administração como privado ou administrativo não tem por si mesma uma transcendência decisiva para a determinação da regulação de fundo de uns e outros. Em toda a classe de contratos da Administração é patente a mescla do Direito Administrativo com o Direito Privado."138

A jurisprudência pátria também adota referida corrente, reconhecendo a existência dos chamados "contratos privados da Administração Pública".

\footnotetext{
${ }^{136}$ Toshio Mukai prefere falar em "contratos administrativos de figuração privada" (MUKAI, Toshio. op. cit., p. 24), enquanto Hely Lopes Meirelles adota a nomenclatura "contratos semipúblicos" (MEIRELLES, Hely Lopes. Direito administrativo brasileiro. 18. ed., cit., p. 194-196), que acreditam expressar melhor o fato de tais contratos não serem regidos única e exclusivamente pelo direito privado. Trata-se da mesma nomenclatura adotada por Carlos Ari Sundfeld (Licitação e contrato administrativo de acordo com as Leis n. 8.666/93 e 8.883/94, cit., p. 199 e ss.) e por Alice Borges Gonzalez (BORGES, Alice Gonzalez. A administração pública como locatária, cit., p. 233).

${ }^{137}$ GARCÍA DE ENTERRÍA, Eduardo; RAMÓN FERNÁNDEZ, Tomás. op. cit., p. 704-705, tradução livre. No original: "Pues bien, hay que advertir que en el caso concreto de los contratos de la Administración la distinción entre los de carácter administrativo y los de carácter privado no remite a regímenes jurídicos irreductiblemente diferentes, sino en buena parte próximos. Hay que notar también que tales regímenes no son unitarios y compactos, es decir, que no hay un solo régimen jurídico para los contratos administrativos y otro para los contratos privados, sino varios regímenes distintos a cada lado de la línea divisoria. Dicho de tro modo, la distinción de regímenes jurídicos se hace más por series o tipos de contratos individualmente considerados que por su calificación genérica como privados o administrados."

${ }^{138}$ GARCÍA DE ENTERRÍA, Eduardo; RAMÓN FERNÁNDEZ, Tomás. op. cit., p. 709, tradução livre. No original: “(...) la calificación de un contrato de la Administración como privado o administrativo no tiene por sí misma una transcendencia decisiva en orden a la determinación de la regulación de fondo de unos y otros. En toda clase de contratos de la Administración es patente la mezcla del Derecho Administrativo y el Derecho Privado".
} 
Nesse contexto, não obstante os contratos privados da Administração Pública sejam regidos, em grande parte, pelas leis civis, não se pode deixar passar despercebido o fato, já mencionado brevemente acima, de que a Administração Pública não tem sua natureza jurídica pública modificada apenas pelo fato de ser parte de um contrato regido majoritariamente pelo direito privado.

Assim, mesmo em um contrato privado da Administração Pública, esta deverá proceder com um certame licitatório previamente à celebração do contrato (ou com processo demonstrador da dispensabilidade ou inexegibilidade da licitação), manterá suas prerrogativas de presunção de solvência e relativas à modalidade contratual ${ }^{139}$, e poderá recorrer ao descumprimento devidamente motivado do contrato. Corroborando tal entendimento, Lúcia Valle Figueiredo defende que "a Administração Pública, consoante entendemos, está, sempre, jungida ao regime de Direito Público em muitos aspectos, ainda que o contrato seja dos que se submetem mais às normas de Direito Privado" ${ }^{140}$.

Dentre os autores que defendem a existência própria de contratos privados da Administração, destacamos Maria Luiza Machado Granziera, que coloca a seguinte observação pertinente ao tema:

“(..) todavia, há contratos em que prevalecem as regras do direito
privado, quando couber. Constituem exceção à regra a referem-se a
objetos em que o fato de a Administração Pública ser parte contratante
não interfere em sua execução. É o caso dos exemplos mencionados no
art. $62,3^{\circ}$, da Lei $\mathrm{n}^{\circ} 8.666 / 93$, relativos aos contratos de seguro, de
financiamento, de locação que o Poder Público seja locatário e aos
demais cujo conteúdo seja regido, predominantemente, por norma de
direito privado" 141 .

Posição similar é a de Marçal Justen Filho:

“(...) ainda que os princípios sejam os mesmos, as regras aplicáveis a um contrato de obra pública não são as mesmas que disciplinam um contrato de seguro. Isso se evidencia pela impossibilidade da modificação unilateral do contrato de seguro, contrariamente ao que se passa no contrato de obra pública"142.

\footnotetext{
${ }^{139}$ Em um contrato de locação, por exemplo, a Administração Pública não será despejada como se um particular fosse, em caso de indimplemento.

${ }^{140}$ FIGUEIREDO, Lúcia Valle. Curso de direito administrativo. 3. ed. São Paulo: Malheiros Ed., 1998. p. 438-439.

${ }^{141}$ GRANZIERA, Maria Luiza Machado. Contratos administrativos: gestão, teoria e prática. São Paulo: Atlas, 2002. p. 98, grifos no original.

${ }^{142}$ JUSTEN FILHO, Marçal. Teoria geral das concessões de serviço público, cit., p. 159.
} 
Por sua vez, Maria Sylvia Zanella Di Pietro propõe a divisão, para efeitos de estudo do regime jurídico aplicável aos contratos da Administração Pública ("lato sensu"), em três categorias distintas ${ }^{143}$ :

a) Contratos tipicamente administrativos - aqueles que não possuem equivalente no âmbito do Direito Privado, porquanto se justifiquem apenas no sistema jurídico administrativo, sendo, portanto, regidos pelo Direito Público. Exemplos: concessão de serviço público, de obra pública ou de uso de bem público.

b) Contratos que possuem equivalentes no direito privado - contratos que, embora típicos da vida privada, podem ser celebrados pela Administração Pública, hipótese em que são regidos também pelo direito público, com a observância de regras específicas. Exemplos: mandato, empréstimo, depósito, empreitada.

c) Contratos de direito privado - contratos regidos meramente pelo Código Civil, independentemente de uma das partes pertencer à Administração Pública. Exemplos: compra e venda, doação, locação, comodato, aquisição de obra de arte.

No entanto, sabe-se que, independentemente do regime jurídico do contrato, a Administração Pública está a todo tempo, em seu agir, condicionada à observância do regime jurídico administrativo. A presença pontual de determinadas características do regime jurídico público (que muitas vezes nem mesmo residem no instrumento contratual, e sim na parte do contrato, integrante da Administração Pública ${ }^{144}$ ) não descaracteriza o contrato como sendo de direito privado, pois a derrogação pode ser considerada parcial:

"Se a derrogação for apenas parcial, com previsão de um ou outro poder
para a Administração, mas sem restringir, em sua essência, a disciplina
jurídica do instituto, dada pelo Código Civil, o contrato continuará sendo
de direito privado. A derrogação do direito comum dar-se-á apenas nos
limites estabelecidos em lei. Em caso de dúvida na interpretação do
contrato, não se cogitará da aplicação de outras cláusulas exorbitantes,
além das expressamente previstas em lei, pois aquelas cláusulas

${ }^{143}$ DI PIETRO, Maria Sylvia Zanella Da aplicação do direito privado no direito administrativo, cit., p. 185.

${ }^{144}$ Nesse sentido: "A Administração é sempre afetada por cláusulas de direito público. Portanto, quando a Administração se relacionar contratualmente com particulares, poderão existir contratos onde haverá uma participação maior de cláusulas de natureza pública, e contratos onde haverá uma participação menor de cláusulas de natureza pública, mas sempre haverá uma conjugação de direito público e privado". DALLARI, Adilson Abreu. op. cit., p. 29. 
consideradas implícitas em todo contrato administrativo não existem nos contratos de direito privado, sem expressa previsão legal.,"145

Todavia, uma importante ressalva deve ser feita: a derrogação parcial do direito privado pelas simples presença da Administração Pública em um dos pólos do contrato não pode implicar em onerosidade excessiva à outra parte, característica esta que levaria à rescisão do contrato com base em previsão expressa do Código Civil:

"Art. 478. Nos contratos de execução continuada ou diferida, $\underline{\text { se a }}$
prestacão de uma das partes se tornar excessivamente onerosa, com
extrema vantagem para a outra, em virtude de acontecimentos
extraordinários e imprevisíveis, poderá o devedor pedir a resolucãóo
do contrato. Os efeitos da sentença que a decretar retroagirão à data da
citação.

Art. 479. A resolução poderá ser evitada, oferecendo-se o réu a modificar equiitativamente as condições do contrato.

Art. 480. Se no contrato as obrigações couberem a apenas uma das partes, poderá ela pleitear que a sua prestação seja reduzida, ou alterado o modo de executá-la, a fim de evitar a onerosidade excessiva." (destacamos)

Ora, como se sabe, a necessidade de realização de procedimento licitatório para a celebração da maior parte dos contratos da Administração Pública pode representar, de fato, um custo adicional aos particulares que pretendam contratar com o Poder Público. Todavia, este é um custo de transação que possui equivalência em negócios privados (como, por exemplo, eventuais requisitos de apresentação de amostra dos potenciais fornecedores, ou de viagens para as negociações que costumeiramente antecedem a celebração de negócios jurídicos).

Assim, fatores previstos em lei e/ou que já possam ser previstos de antemão ao celebrar um contrato com a Administração Pública não dão ensejo à alegação de onerosidade excessiva como forma de rescisão contratual. Apenas fatores extraordinários é que poderiam motivar referida modalidade de rescisão, mesmo em contrato ao qual se aplique o direito privado.

\footnotetext{
${ }^{145}$ DI PIETRO, Maria Sylvia Zanella Da aplicação do direito privado no direito administrativo, cit., p. 187.
} 


\section{Das consequências da aplicação de regime jurídico privado aos contratos celebrados pela Administração Pública}

Para Diogo Freitas do Amaral, a Administração Pública, integrada por diversas pessoas jurídicas, não é regulada apenas por um regime jurídico, mas por dois (direito administrativo e direito civil) ou três, se contabilizado o que o Autor chama de "Direito Privado Administrativo", que é "um direito específico dos sujeitos de direito público, mas não é Direito Administrativo: aquele, sim, é um direito estatutário; este porém não o é, porque o âmbito de aplicação do Direito Administrativo se define objectivamente, em função da actividade administrativa de gestão pública, e não subjectivamente, em função das pessoas colectivas públicas."146

Independentemente de se reconhecer a existência de um "Direito Privado Administrativo", a noção supra transcrita demonstra que há, efetivamente, uma mistura dos regimes jurídicos público e privado para a atuação das pessoas jurídicas de direito público, integrantes da Administração Pública direta e indireta. Assim, para a celebração de negócios jurídicos, outra não poderia ser a conclusão, senão a de que haverá casos em que prevalescerá o direito privado, enquanto em outras situações será o direito público que se manifestará em maior proporção.

Parte da doutrina nacional destaca que a aplicação do regime jurídico privado aos contratos em que o Poder Público é parte permite a adoção de algumas faculdades peculiares, como, por exemplo, a adoção de métodos de resolução de conflito alternativos.

A utilização da via arbitral de resolução de conflitos, todavia, decorre da existência

\footnotetext{
${ }^{146}$ AMARAL, Diogo Freitas do. Curso de direito administrativo. 2. ed. Coimbra: Almedina, 1994. v. 1, p. 142-143. Após cogitar o direito administrativo como direito excepcional ao direito ordinário privado, como direito comum da Administração e como o direito ordinário do exercício da função administrativa, optando por este último como o entendimento correto (Id. Ibid., p. 140). Nos parece que o direito administrativo é efetivamente a regra no agir da Administração Pública, sendo o direito privado sua exceção. No entanto, acreditamos que cogitar um "Direito Privado Administrativo" é exagero, sendo que o fenômeno que efetivamente ocorre com a Administração Pública é a conjunção entre o seu regime jurídico ordinário (direito administrativo, aplicável em virtude de sua natureza jurídica pública) e o regime jurídico especial, aplicável a alguns casos específicos (direito civil, decorrente do fato de a Administração Pública ser integrada por pessoas jurídicas que praticam atos característicos da voda civil, ainda assim com certa influência do regime jurídico ordinário).
} 
de direitos disponíveis em questão, e não necessariamente do regime jurídico aplicável ${ }^{147}$. Assim, muito embora nosso entendimento seja o de que a arbitragem possa vir a ser adotada tanto em contratos administrativos quanto em contratos privados da Administração Pública, sua previsão não pode ser genérica - o que faria com que, em tese, se pudesse utilizar tal via em toda e qualquer discussão relacionada ao contrato em que foi eleita como via adequada para solução de divergências e conflitos -, sendo necessário restringi-la àqueles casos em que o objeto de divergência/conflito seja, em tese, passível de negociação pela Administração Pública.

Isso porque, via de regra, sempre que houver interesse público em jogo, não caberá à Administração Pública transacionar, visto que este é indisponível pelo Estado ${ }^{148}$. Ora, se no Estado Democrático de Direito a população outorga poderes de representação ao Poder Público para que este cuide dos interesses da sociedade, tal mandato se restringe à defesa incessante do interesse público. Não haveria como reputar que tal mandato se estende à possibilidade de negociação do interesse público, pois não há como obter o consenso da coletividade neste tipo de negociação e, portanto, ele se torna inabdicável pelo mandatário.

Ocorre, no entanto, que, via de regra, aqueles contratos da Administração Pública regidos predominantemente pelo direito privado se referem a negócios jurídicos ordinários, como a compra e venda, a locação, a doação, a contratação de seguros etc. Esta classe de negócios jurídicos envolve primariamente interesses patrimoniais do Estado que, via de regra, são disponíveis e, portanto, podem ser objeto de transação (o que inclui a possibilidade de adoção de meios alternativos de resolução de conflitos).

Portanto, em tese, apenas excepcionalmente poderá o Estado transacionar em casos que envolvam interesses públicos. Mesmo nestes casos excepcionais, tal faculdade somente é admitida se a transação tiver como única finalidade (e na medida estritamente necessária

\footnotetext{
${ }^{147} \mathrm{O}$ art. $1^{\circ}$ da Lei Federal n. ${ }^{\circ}$ 9.307/1996, que trata da utilização da arbitragem no sistema jurídico brasileiro, determina que tal mecanismo pode ser utilizado para "dirimir litígios relativos a direitos patrimoniais disponíveis". Tendo em vista que, via de regra, os contratos privados da Administração Pública têm como objeto exatamente direitos patrimoniais disponíveis, comportam meios alternativos de solução de controvérsias. Por sua vez, os contratos administrativos muitas vezes lidam com interesses públicos e, por esta razão, a análise sobre a inclusão de cláusulas compromissórias deve ser mais detalhada. De qualquer maneira, há proliferação de trabalhos voltados ao tema, aliada à jurisprudência e à inclusão do art. 23-A na Lei Federal n. ${ }^{\circ}$ 8.987/1995 (Lei Federal de Concessões) mostra ser, ao menos em parte, possível a adoção de meios alternativos de solução de controvérsia em contratos administrativos.

${ }^{148}$ Discussão crescente aparece no campo do direito sancionados da Administração Pública, em que se mostra crescente a tendência de possibilitar transações em infrações de menor escala para garantir maior eficiência punitiva, educacional e de ganho para a sociedade.
} 
a ela), devidamente comprovada por ocasião da transação, justamente a preservação do próprio interesse público na maior extensão possível, nas situações de iminente ameaça à totalidade do interesse público, como bem observa Márcia Walquíria Batista dos Santos: "poderá a Administração, em situações de absoluta excepcionalidade e a fim de evitar danos maiores ao próprio interesse público, compor com o particular de forma a atingir benefícios maiores à comunidade."

Dizemos que a transação envolvendo interesse público para sua própria preservação pode ocorrer em tese porque na prática é difícil vislumbrar-se que isto ocorra (de maneira legítima), pois envolve uma série de decisões discricionárias do Poder Público em matéria crítica (interesse público) e indisponível: (i) verificar que, de fato, existe uma situação ameaçadora da integralidade de interesse público; (ii) constatar que há a possibilidade de uma transação que irá, sem sombra de dúvida, preservar grande parte do interesse público e que sem referida transação o interesse público será eliminado em sua totalidade (ou pelo menos em maior parte); e (iii) decidir qual parte do interesse público será utilizada na transação. Isto sem falar nos casos em que a transação, depois de concretizada, se mostre insuficiente ou inadequada para a preservação do interesse público e, assim, desapareça sua única razão de existir, pondo em xeque a sua legitimidade e levando à necessidade de avaliação das conseqüências para se necessário, punir os culpados.

Percebe-se, assim, que o risco envolvido na realização de qualquer transação envolvendo interesse público é enorme, podendo resultar no reconhecimento da sua nulidade - por ausência de mandato para realizá-la ou por inadequação - e/ou na responsabilização dos agentes públicos.

Como parte da doutrina costuma destacar, um dos critérios de diferenciação entre os contratos administrativos e os contratos privados da Administração Pública passível de adoção pelo intérprete é a presença (ou ausência) de cláusulas estranhas ao direito civil, que tipicamente estipulam prerrogativas públicas extraordinárias, como poder de modificação unilateral, rescisão contratual unilateral, poder de fiscalizar e punir. As cláusulas representativas destas prerrogativas não seriam, via de regra, comportadas pelos contratos típicos do direito privado, empregados para os negócios jurídicos ordinários da

\footnotetext{
${ }^{149}$ SANTOS, Márcia Walquíria Batista dos. Cláusulas exorbitantes: da teoria à prática. In: DI PIETRO, Maria Sylvia Zanella; RIBEIRO, Carlos Vinícius Alves. Supremacia do interesse público e outros temas relevantes do direito administrativo. São Paulo: Atlas, 2010. p. 393.
} 
Administração Pública.

Assim, o fato de constatar-se que um determinado contrato celebrado pela Administração Pública é regido predominantemente pelo direito privado leva, por conseguinte, à conclusão de que não há lugar para cláusulas de direito público. Isto não quer dizer, no entanto, que mediante a necessária motivação o Poder Público contratante não possa exercer prerrogativas decorrentes de sua própria natureza jurídica (pública), que sempre permanece inalterada, independentemente do regime jurídico preponderante do contrato.

Via de regra, portanto, a Administração Pública não poderá fazer valer suas prerrogativas dentro de um contrato privado. Apenas excepcionalmente, em casos em que algum interesse público direta ou indiretamente ligado ao contrato esteja em jogo é que, motivadamente, o Poder Público poderá se sobressair, deixando uma posição de equivalência quanto à(s) outra(s) parte(s) do contrato. 


\section{CAPÍTULO II. O PAPEL DAS CLÁUSULAS CARACTERÍSTICAS DE DIREITO PÚBLICO}

\section{Introdução}

As cláusulas contratuais características do regime de direito público sempre receberam da doutrina e da jurisprudência papel de destaque na análise dos contratos celebrados pela Administração Pública. Isto porque, ao trazerem consigo prerrogativas que não são típicas do direito privado, acabam por demonstrar que, ao menos em parte, deve-se aplicar, ao instrumento contratual em que foram inseridas, regras de direito público.

A doutrina, em sua maior parte, habituou-se a denominar tais cláusulas de "exorbitantes" ou "derrogatórias". Isto ocorre por se partir do pressuposto de que contratos são figuras representativas dos negócios jurídicos que nasceram com o direito privado, muito embora residam atualmente na seara da Teoria Geral do Direito. Assim, as regras de direito público seriam "extraordinárias", atípicas em um instrumento que se pressuponha advir do direito privado (e, assim, estariam fora da órbita - exorbitantes - do direito ordinário, prevalecendo - derrogando - o direito privado).

Toda a discussão travada pela doutrina acerca da exatidão dessa nomenclatura ${ }^{150}$

\footnotetext{
${ }^{150}$ Maria João Estorninho afirma que um “complexo de exorbitância” sempre imperou sobre os administrativistas que analisaram o tema dos contratos administrativos, no sentido de procurar sempre afastar o conceito de contrato administrativo dos contratos comuns de direito privado e que apenas recentemente e paulatinamente vem-se admitindo que o regime jurídico do contrato administrativo é compatível com o direito contratual comum (ESTORNINHO, Maria João. Réquiem pelo contrato administrativo, cit., p. 183). Por sua vez, Cretella Júnior critica a utilização destas nomenclaturas porque tomam como referência o direito civil, quando na verdade deveriam se focar no regime jurídico que lhe é aplicável, qual seja, o de direito público. Nesse sentido, observa que "na realidade, não ocorre nem 'derrogação', nem 'exorbitância', mas apenas diferenças específicas, sabidamente existentes nas espécies, ao serem confrontadas com os respectivos gêneros de que descendem" (CRETELLA JÚNIOR, José. Dos contratos administrativos. Rio de Janeiro: Forense, 1998. p. 39). Por esta razão, o Autor propõe a adoção da terminologia "cláusula de privilégio", mais fidedigna ao propósito de tratar de cláusula que representa a aplicação do direito público, pois é tautológico afirmar que o direito público é derrogatório do direito privado, na medida em que o direito privado é igualmente exorbitante ao direito público. Apenas para efeito de registro, concordamos com a opinião de José Cretella Júnior: mesmo que inegavelmente os contratos sejam institutos característicos de direito privado, isto não significa que todos os contratos celebrados pela Administração Pública sejam advindos diretamente do direito privado e, portanto, não se deveria tomar o direito privado como ponto de referência para a abordagem de cláusulas de direito público. Contratos como
} 
nos parece carecedora de relevância prática para o estudo ora realizado, razão pela qual utilizaremos indistintamente as nomenclaturas adotadas pela doutrina (cláusulas exorbitantes, derrogatórias, de privilégio, verticais, de prerrogativa ou administrativas). A nomenclatura não muda o conteúdo nem tampouco a natureza destas cláusulas, que são inegavelmente típicas do regime jurídico público, representando prerrogativas que somente podem prevalecer quando uma das partes tem natureza jurídica pública ou representa algum ente de tal natureza.

Conforme mencionado quando da análise dos diversos critérios de diferenciação das modalidades de contratos da Administração Pública, as cláusulas de prerrogativas da Administração Pública são característica que indica - ao menos em parte - a presença do regime de direito público em um determinado contrato. O exercício das prerrogativas públicas representadas por elas é manifestação do poder extroverso ${ }^{151}$ da Administração Pública e, neste contexto, seu exercício não depende da discricionariedade pública, pois é, antes de tudo, um poder-dever. Como bem ressalta Vladimir da Rocha França ${ }^{152}$, "não se nega que o exercício das cláusulas exorbitantes é efetuado por meio de ato unilateral e que essas prerrogativas são indispensáveis para o interesse público, sendo insuscetíveis de derrogação por vontade das partes envolvidas na avença."

No entanto, tais cláusulas somente podem constar de contrato quando houver legitimidade para que ao menos uma das partes do contrato faça uso de prerroghativa peculiar perante ao menos uma outra parte. E isto somente ocorrerá naqueles casos em que algum ente da Administração Pública direta ou indireta seja parte do contrato, ou então naqueles casos em que um representante da Administração Pública (um concessionário de serviço público, por exemplo) participe do contrato, no exercício de função delegada.

Maria João Estorninho defende que mesmo em contratos celebrados entre entes privados e de regime jurídico unicamente privado poderia haver poderes de exercício de

o de concessão e o de uso de bem público, por exemplo, possuem tantas peculiaridades que não seria desarrazoado que se defendesse se tratar de institutos característicos de direito público, mesmo recebendo a nomenclatura de "contratos". Não obstante, não se pode deixar de ignorar o fato de que a maior parte da doutrina usualmente se refere às cláusulas contratuais de direito público como "cláusulas exorbitantes", razão pela qual também as utilizaremos por vezes no presente trabalho.

${ }^{151}$ Que, nos dizeres de Celso Antônio Bandeira de Mello, é aquele "que permite ao Poder Público editar provimentos que vão além da esfera jurídica do sujeito emitente, ou seja, que interferem na esfera jurídica de outras pessoas, constituindo-as unilateralmente em obrigações" (BANDEIRA DE MELLO, Celso Antônio. Curso de direito administrativo. 17. ed. São Paulo: Malheiros Ed., 2004. p. 383).

${ }^{152}$ FRANÇA, Vladimir da Rocha. op. cit., p. 7. 
prerrogativas unilaterais e executórias e que haveria normas de direito civil que supostamente admitiriam tal situação (sem, contudo, citar quais seriam especificamente estar normas). Tal Autora entende que é "perfeitamente admissível ao abrigo da autonomia privada das partes" $" 153$ negociar a presença de prerrogativas do gênero.

Da mesma forma, Rafael Véras de Freitas ${ }^{154}$, socorrendo-se de lição de Diogo de Figueiredo Moreira Neto ${ }^{155}$, demonstra compartilhar do entendimento de que as cláusulas exorbitantes não deveriam constar de todos os contratos da Administração Pública, pois estas seriam desvantajosas em certa medida por aumentarem os custos de transação pelo aumento dos riscos envolvidos, imprecisão e insegurança dos direitos e obrigações envolvidos e sacrifício da confiança legítima dos particulares no negócio jurídico.

Diante de tal opinião, o Autor propõe que

\begin{abstract}
"sejam adotadas as técnicas de flexibilização pela discricionariedade e da dupla motivação, de modo que a inserçào e a formulação da cláusulas exorbitantes nos contratos possa ser feita discricionariamente pelo administrador, que deverá motivar tanto a adoção (inserção no contrato), em tese, da cláusula discricionária, como, também, a sua aplicação, quando necessária, já que o atendimento do princípio do interesse público é que é legalmente indisponível por parte da Administração, mas as condições em que esse atendimento se dará ou se possa dar é matéria administrativamente disponível, sempre que se instaure concurso com outros princípios constitucionalmente relevantes."
\end{abstract}

Embora tal corrente de pensamento tenha seu mérito, não concordamos com ela: as prerrogativas públicas poderão ser exercidas legitimamente sempre que comprovadamente

\footnotetext{
${ }^{153}$ ESTORNINHO, Maria João. Réquiem pelo contrato administrativo, cit., p. 147.

${ }^{154}$ FREITAS, Rafael Véras de. op. cit., p. 130.

${ }^{155}$ MOREIRA NETO, Diogo de Figueiredo. O futuro das cláusulas exorbitantes nos contratos administrativos. Revista da Associação dos Procuradores do Novo Estado do Rio de Janeiro, Rio de Janeiro, n. 17, p. 3-22, 2006; e em MOREIRA NETO, Diogo de Figueiredo. O futuro das cláusulas exorbitantes nos contratos administrativos. In: ARAGÃO, Alexandre Santos de, MARQUES NETO, Floriano de Azevedo (Coords.), cit., p. 582. Destaca-se as seguintes passagens relevantes da opinião do Autor: "Ora, no modelo tradicional de contratos administrativos - com prerrogativas legais estandartizadas - há total impossibilidade de ponderar casuisticamente essas vantagens e desvantagens considerando as características de cada um para que deva realizar a Administração Pública (juizos de oportunidade e de conveniência)." (p. 582) "Com essaperspectiva em mente, já em meu Curso deixou-se de consignar a expressão cláusulas exorbitantes, porque implicitamente evoca o caráter revocatório do Direito Privado e, destarte, a ultrapassada teoria que lhe atribuía substantividade principiológica, preferindo-se utilizar expressões que se limitam a acentuar o seu assento legal ou mesmo contratual, como as que nele foram empregadas ao tratar da característica da instabilidade dos contratos administrativos, tais como as expressões cláusulas regulamentares $e$ leis de serviço." (p. 591).

${ }^{156}$ FREITAS, Rafael Véras de. op. cit., p. 131.
} 
houver interesse público envolvido e seu exercício seja motivado. No entanto, é justamente para que o particular saiba dos riscos e peculiaridades de contratar com a Administração Pública que a legislação e/ou os contratos trazem a previsão da possibilidade potencial de seu exercício, lembrando sempre que virão acompanhadas da compensatória manutenção das cláusulas econômico-financeiras, estabelecendo claramente as regras do jogo e permitindo a manutenção do interesse privado.

Nosso entendimento é o de que a Administração Pública, muitas vezes contratando com administrado que pode ser considerado hipossuficiente (ou, ao menos, dotado de condição inferior ou não equivalente à do Poder Público), poderá vir a impor prerrogativas, direitos e condições que, em um ambiente exclusivamente privado, podem ser considerados abusivos e passíveis de invalidação e reconhecimento de nulidade $^{157}$.

Em raciocínio semelhante, Maria Sylvia Zanella Di Pietro defende que "muitas das cláusulas exorbitantes são possíveis também nos contratos de direito privado, bastando, para isso, que as partes, de comum acordo, as estipulem; isto em decorrência do princípio da autonomia da vontade, que informa o regime contratual privado"158.

Nossa opinião é a de que mesmo sendo admissível o desnivelamento entre as partes de um contrato exclusivamente privado (do qual a Administração Pública não seja parte), esta é uma situação extraordinária e excepcional que requer fato que a justifique e que impeça que o contrato venha a ser classificado como leonino e que reputado como nulo/anulável.

Outrossim, de modo algum este desnivelamento entre partes privadas se assemelhará àquele existente entre um ente privado e um ente público. E é a própria Maria João Estorninho quem o admite, ainda que parcialmente, ao afirmar que "o que me [1he] parece específico [nos contratos administrativos, quando comparados aos contratos privados, no tocante às prerrogativas] é apenas o facto de a Administração ser dotada desta possibilidade [de exercício unilateral de prerrogativas] independentemente de

\footnotetext{
${ }^{157}$ Nesse sentido: ARAÚJO, Edmir Netto de. Contrato administrativo. São Paulo: Ed. Revista dos Tribunais, 1987. p. 156; CRETELLA JÚNIOR, José. As cláusulas "de privilégio" nos contratos administrativos. Revista de Direito Administrativo, Rio de Janeiro, n. 161, p. 7, 1985; WALINE, Marcel. Droit administratif. 9. ed. Paris: Sirey, 1963. p. 572; ROUVIÈRE, Jean. Les contrats administratifs. Paris: Dalloz, 1930. p. 161; RIVERO, Jean. Droit administratif. 5. ed. Paris: Dalloz, 1971. p. 109.

${ }^{158}$ DI PIETRO, Maria Sylvia Zanella Da aplicação do direito privado no direito administrativo, cit., p. 179.
} 
previsão legal"159.

Desta maneira, a presença de cláusulas exorbitantes ou derrogatórias - que, como a própria nomenclatura indica, extrapolam o regime jurídico civil - em contratos privados nos parece ser uma decorrência de posição diferenciada ${ }^{160}$ da Administração Pública frente ao particular - posição esta que, em tese, em um contrato exclusivamente privado deveria ser de equidade e isonomia -, e não do princípio da autonomia da vontade.

A propósito, a nomenclatura adotada por José Cretella Júnior, de "cláusulas de privilégio"161 evidencia a sua total incompatibilidade com contratos regidos totalmente pelo direito privado, ou seja, daqueles em que a Administração Pública e/ou seus representantes não sejam parte.

Não pode passar sem registro no presente estudo o fato de que alguns autores recentemente passaram a criticar de forma mais veemente a aplicação de cláusulas exorbitantes em contratos da Administração Pública, alegando principalmente que tais cláusulas não são imponíveis sobre direitos fundamentais e seriam, mesmo, incompatíveis com o Estado Democrático de Direito ${ }^{162}$.

Em que pese tal corrente ter razão no tocante à ausência de caráter absoluto das cláusulas exorbitantes - até porque a legislação pátria não as coloca e nem poderia colocálas em patamar superior a princípios e direitos consagrados na Carta Magna -, não concordamos com a opinião de que tais cláusulas poderiam ser consideradas totalmente incompatíveis com o sistema jurídico em vigor.

\footnotetext{
${ }^{159}$ ESTORNINHO, Maria João. Réquiem pelo contrato administrativo, cit., p. 147.

${ }^{160}$ É de se notar que entendemos que a posição da Administração Pública frente ao particular é "diferenciada", e não "privilegiada", como impropriamente se refere parte da doutrina (que pode ser exemplificada por SANTOS, Márcia Walquíria Batista dos. Cláusulas exorbitantes: da teoria à prática, cit., p. 387). Isto porque, se de um lado cabem à Administração Pública as prerrogativas de modificar ou rescindir unilateralmente o contrato, a elas correspondem o direito do administrado (e o correlato dever público) de preservar a equação econômico-financeira da relação.

${ }^{161}$ CRETELLA JÚNIOR, José. As cláusulas “de privilégio" nos contratos administrativos, cit., p. 7-28.

${ }^{162}$ Nesse sentido: ESTORNINHO, Maria João. Réquiem pelo contrato administrativo, cit., p. 153 e ss.

Opinião intermediária é a de Diogo de Figueiredo Moreira Neto, para quem a tendência do Direito Administrativo contemporâneo seria a de flexibilizar suas técnicas de contratação, abandonando o que para ele seria uma "técnica rígida da vinculação" (MOREIRA NETO, Diogo de Figueiredo. O futuro das cláusulas exorbitantes nos contratos administrativos. In: ARAGÃO, Alexandre Santos de, MARQUES NETO, Floriano de Azevedo (Coords.), cit., p. 585-586. Em que pese o mérito da opinião abalizada, nosso entendimento é o de que contrato é, via de regra, vinculação, e é justamente esta sua característica que permite que funcione como ferramenta de apaziguação social. É claro que não se está a afirmar que não há espaço para transacionar e negociar. Sempre que houver direitos disponíveis em jogo, esta será uma possibilidade.
} 


\section{A relação das prerrogativas públicas com os contratos}

Negar, de maneira genérica e geral, a possibilidade de o Poder Público possuir determinadas prerrogativas previstas em lei e exercíveis de maneira motivada é ignorar a natureza jurídica peculiar da Administração Pública, bem como o fato de ser mandatária da população para defender o interesse público.

Carlos Ari Sundfeld, embora falando especificamente sobre contratos administrativos, aponta que a inserção de cláusulas exorbitantes em um acordo da Administração Pública não retira a natureza contratual do instrumento, até porque a elas corresponde a estabilizaçào da equação econômico-financeira, contrapartida significativa:

"Porém, o vínculo obrigacional em si não é instável, porquanto à definição (ou redefinição) exata do objeto, procedida pela Administração no curso da execução, corresponde uma definição (ou redefinição) do montante da remuneração do particular, nos termos da equação econômico-financeira consensualmente estabelecida, e que é intangível. Em outras palavras: no contrato administrativoem sentido estrito, a Administração tem o poder de, por variados atos posteriores à sua celebração, determinar exatamente o objeto do vínculo, mas não tem a faculdade de escapar dele mesmo (nem mesmo quando dão por findo o contrato antes do prazo, porque também nesse caso há reflexos patrimoniais determinados pela equação econômico-financeira)." ${ }^{\text {"163 }}$

Assim, utilizar a existência de limites ao exercício de prerrogativas públicas para propor o fim das cláusulas exorbitantes ${ }^{164}$ (e, com isso, o fim dos contratos

\footnotetext{
${ }^{163}$ SUNDFELD, Carlos Ari. op. cit., p. 212-213.

${ }^{164}$ Maria Paula Dallari Bucci apresenta uma análise bastante elucidativa do assunto: "Nessa linha, a doutrina administrativista questiona-se hoje sobre a 'fuga da Administração para o direito privado'. No fundo ou por trás desse movimento, cogita-se de estar a Administraçãobuscando, mais que despir-se das prerrogativas, escapar às sujeições típicas do regime administrativo.

Mas deve-se notar, em paralelo, a existência de um amplo movimento de contratualização da atividade administrativa, que se reveste de múltiplas formas (e no Brasil recente é exemplo disso a recente introdução do $\$ 8^{\circ}$ do artigo 37 da Constituição Federal, com a figura do contrato de gestão), a indicar realmente a crise da idéia de prerrogativa e do 'poder de império' a ela subjacente. Odete Medauar noticia que 'a prerrogativa de modificar unilateralmente o contrato, como algo absoluto, vem sendo contestada modernamente. No ordenamento italiano, a Corte de Cassação afastou a tese do poder discricionário de modificação unilateral do contratio, como poder geral independente de previsão legal explícita; afirmou que, salvo a rescisão por interesse público, a relação contratual é regida por cânones paritários'.

No plano político, essa idéia corresponderia, no mínimo, à busca de uma legitimação da ação administrativa pelo consenso. Talvez esse movimento não indique exatamente a crise do direito especial em favor do direito comum, mas a crise da noção de ato administrativo, unilateral, em favor da noção de
} 
administrativos) nos parece ser proposta extremada que acaba por desprezar o princípio da indisponibilidade do interesse público.

Da mesma forma que reside interesse público na preservação dos direitos fundamentais, há interesse público também na prorrogação extraordinária, por exemplo, de um contrato de locação de imóvel utilizado como hospital para prestar socorro a vítimas de queimaduras de um acidente de grandes proporções ou no aumento da quantidade de uniformes fornecidos aos funcionários públicos ali lotados, causados por atitude unilateral da Administração Pública contratante ${ }^{165}$.

Pode-se até se discutir a melhor forma de redigir tais cláusulas, mas jamais eliminar aquilo que elas representam, a sua essência, que é a existência de prerrogativas inerentes à Administração Pública, mas não eliminá-las do mundo jurídico, pois sua base legitimadora é o interesse público, que não é passível de transação ${ }^{166}$.

Por outro lado, a importância da preservação das cláusulas exorbitantes em razão daquilo que representam não significa que instrumentos de comprovada eficiência que tenham se originado em negócios jurídicos puramente privados não possam ser adotados.

Não nos parece que o legislador, os juristas e/ou a jurisprudência tenham cogitado em algum momento dentro do contexto contemporâneo que as prerrogativas públicas consubstanciadas em cláusulas contratuais ditas exorbitantes do regime comum pudessem ser utilizadas para fazer letra morta da Constituição Federal e subjugar direitos

atividade, à qual subjaz a de procedimento, como destaca Maria João Estorninho, ao referir o caso alemão: 'Os contratos jurídico-públicos admitidos pela lei não passariam de meros 'atos administrativos com participação especialmente intensa do destinatário’’. Essa tendência é um exemplo do fardo autoritário subjacente à perspectiva subjetiva das prerrogativas da Administração Pública, concomitantemente à inadequação da fundamentaçãoobjetivista, cujo teor, hoje, está a reclamar maior espaço às figuras da participação popular, da motivação e da transparência administrativa, em lugar de prerrogativas herméticas" (BUCCI, Maria Paula Dallari. Direito administrativo e políticas públicas. São Paulo: Saraiva, 2002. p. 254).

${ }^{165}$ Esclareça-se que não se está a equiparar direitos fundamentais com intersses de fornecimento, mas sim a afirmar que há interesse público tanto em um caso como em outro. É claro que numa situação em que a Administração tenha que escolher entre um e outro, deverá se pautar pela preservação dos direitos fundamentais, mesmo que em prejuízo de interesses patrimoniais do Estado (e, em consequência, da coletividade).

${ }^{166} \mathrm{E}$, neste ponto, não se deve confundir a impossibilidade de transação com a possibilidade de cedência, apenas na medida do essencial, diante de outro interesse público mais relevante (confronto ou concurso de interesses), muito semelhante à mecânica da cedência recíproca de princípios da seara constitucional (sobre esta cedência, é útil a metodologia proposta em MOREIRA NETO, Diogo de Figueiredo. O futuro das cláusulas exorbitantes nos contratos administrativos. In: ARAGÃO, Alexandre Santos de, MARQUES NETO, Floriano de Azevedo (Coords.), cit., p. 590). 
fundamentais, simplesmente por ser tal atitude totalmente incompatível com o ordenamento jurídico em vigor.

Portanto, tomar as cláusulas exorbitantes como se fossem carta branca para o bel prazer da Administração Pública é desvirtuar sua real função e constitui tentativa de generalizar a casuística ilegal que se pode presenciar vez ou outra, que ocorre em total desconformidade com o direito administrativo. Deve-se combater a tentação de generalizar, pois ela leva justamente a iniciativas extremadas que acabm resultando em que alguns autores defendam o fim do próprio objeto de seu estudo.

Nesse contexto, um dos principais argumentos que parece embasar a opinião dos autores que sugerem mitigar as cláusulas exorbitantes é o fato de partirem do pressuposto de que toda prerrogativa atribuída à Administração Pública decorre da assimetria entre Administração e administrados, que por sua vez adviria da imperatividade do Poder Público, com raízes imperialistas. Assim, adotando este pressuposto - que nos parece incompleto, eis que referida assimetria, na realidade, é fruto (como, ademais, já afirmamos anteriormente nesse trabalho) também da própria natureza jurídica peculiar da Administração Pública e do mandato que lhe é outorgado pela população -, alguns autores sugerem mitigar tais cláusulas para, com isto, conferir um caráter mais igualitário aos contratos da Administração Pública.

Diogo de Figueiredo Moreira Neto ${ }^{167}$, por exemplo, defende existir atualmente um único regime jurídico aplicável a todos os contratos celebrados pela Administração Pública, com diferentes modulações e intensidades de direito público e de direito privado, não sendo mais correto se colocar uma barreira diferenciadora entre duas modalidades distintas de contratos da Administração Pública. Coloca, neste contexto, que uma aproximação das formas de contratação puramente privadas poderia conferir um maior nível de eficiência ao agir administrativo.

Muito embora com seu mérito, não concordamos com tal opinião, pois reconhecemos que o exercício de prerrogativas sempre será uma possibilidade concretizável, nos limites da razoabilidade e proporcionalidade, quando da demonstração da existência de interesse público previsto genericamente em lei, de maneira que nos

\footnotetext{
${ }^{167}$ MOREIRA NETO, Diogo de Figueiredo. O futuro das cláusulas exorbitantes nos contratos administrativos. In: ARAGÃO, Alexandre Santos de, MARQUES NETO, Floriano de Azevedo (Coords.), cit., p.579-581.
} 
parece ser mais correto e justo com o particular evidenciar tal possibilidade - na legislação ou no próprio contrato - para evitar surpresas e questionamentos futuros. Além disso, a eficiência (introduzida no caput do art. 37 da Constituição Federal pela Emenda Constitucional n. ${ }^{\circ}$ 19/1998 como parte da chamada "Reforma Administrativa"168) como um princípio administrativo apresenta conceito diferente do econômico ${ }^{169}$, largamente difundido na doutrina.

Também não se pode deixar de ressaltar que pregar uma aproximação do direito comum apenas a título de busca de maior atratividade para o setor privado e de melhor acompanhamento das evoluções do mercado não nos parece ser motivo por si só suficiente para relegar a plano secundário o que, a nosso ver, é o motivo legitimador de toda ação administrativa, qual seja, o interesse da coletividade. ${ }^{170}$

É necessário sempre se ater à real função das cláusulas ditas exorbitantes, importantes ao exercício motivado de prerrogativas benéficas ao interesse público. Contrario sensu, o emprego da utilização deturpada (e, portanto, anulável) das cláusulas exorbitantes não pode servir de argumento ao combate das prerrogativas que representam sob a injustificada bandeira de defesa da democracia e da igualdade entre partes (ente privado e Administração Pública) que, por natureza, são distintas.

Assim, portanto, desde já fica consignado nosso entendimento de que as cláusulas exorbitantes desempenham, ainda hoje, papel fundamental nos contratos administrativos e que, ademais, as prerrogativas que elas representam podem, em tese e potencialmente, ser acionadas mesmo naqueles contratos em que referidas cláusulas não se encontrem

\footnotetext{
${ }^{168}$ Sobre o assunto, ver MOREIRA NETO, Diogo de Figueiredo. Apontamentos Sobre a reforma administrativa. Rio de Janeiro: Renovar, 1999.

${ }^{169}$ Sobre o assunto, já tivemos a oportunidade de ressaltar que "a noção constitucional de eficiência foge ao conceito puramente econômico (atividade sustentável), residindo numa esfera de regulação permeada de caráter social, fora da lógica privada do lucro e agregando a si aspectos como atuação ampla e efetiva, ainda que contabilmente injustificável. Isso significa dizer, por exemplo, que uma ação do Estado brasileiro (ou de quem lhe faça as vezes, ainda que o responsável, em última instância, seja sempre o Estado) reputada como essencial, que seja altamente superavitária mas que não abranja todos os cidadãos de maneira isonômica não será eficiente. Por outro lado, uma utilidade pública notadamente onerosa ao Tesouro e que não siga uma lógica econômica, mas que indiscutivelmente proveja os cidadãos brasileiros da garantia de qualquer direito fundamental não só será totalmente justificável, como perfeitamente eficiente." (CARVALHAES NETO, Eduardo Hayden. Regulação da universalização de serviços públicos concedidos: o caso brasileiro dos Serviços de Telecomunicações. Dissertação (Mestrado) - Faculdade de Direito, Universidade de São Paulo, São Paulo, 2007. p. 40).

${ }^{170}$ Ademais, instrumentos que se tornaram usuais nos negócios jurídicos privados, como, por exemplo, o uso de meios alternativos de solução de disputas e apresentação de garantias também pelo setor público podem ser aplicados em contratos em que o Poder Público seja parte, desde que mediante o correto procedimento e com as devidas adaptações devidas pela incidência - ainda que parcial - do direito público.
} 
(devendo, neste caso, haver cautela redobrada na sua motivação e demonstração objetiva da presença de elementos extraordinários justificadores de seu acionamento).

\section{Semelhanças entre as modalidades de contratos da Administração Pública}

Diversas são as semelhanças entre os contratos privados da Administração Pública e os contratos administrativos: em ambos os casos os contratos são "intuitu personae", a competência para contratar decorre de lei ${ }^{171}$, há necessidade de licitação ${ }^{172}$, presença de finalidade pública, forma escrita, dever de publicidade e motivação.

Sobre o assunto, Georges Péquignot afirma:

“(...) [O]s dois tipos de contratos da Administração obedecem para a sua formação a um certo número de regras comuns com vistas tanto à organização administrativa quanto à natureza contratual do ato considerado. Tais regras, devido ao fato de que ao menos um dos cocontratantes é uma pessoa administrativa, submetem-se, quanto à sua atribuição ou ao exercício de suas competências, à influência do Direito administrativo, são muitas vezes, mesmo para os contratos de direito privado, diferentes daquelas de direito comum (...)."173

Isso porque (i) independentemente do regime jurídico preponderante sobre o contrato, a natureza jurídica da Administração Pública continua sendo uma só (pública); e (ii) as espécies contrato administrativo (ramo do direito público) e contrato privado da Administração Pública (ramo do direito privado) pertencem a um só gênero (contrato) da Teoria Geral do Direito, conforme já afirmado acima.

Como consequência desses fatores, como já se afirmou anteriormente neste trabalho, nenhuma das modalidades de contratos da Administração Pública se submete

\footnotetext{
${ }^{171}$ Efeito do princípio da legalidade estrita consignado no caput do art. 37 da Constituição Federal.

${ }^{172}$ Conforme art. 37, XXI da Constituição Federal.

${ }^{173}$ PÉQUIGNOT, Georges. op. cit., p. 3. No original: “(...) [L]es deux sortes de contrats de l'Administration obéissent pour leur formation à un certain nombre de règles communes qui tiennent soit à l'organisation administrative, soit à la nature contractuellede l'acte considéré. Ces règles, à raison de ce que l'un des cocontractants au moins est unne personne administrative, soumise, quant à ses attributions ou à l'exercice de ses compétences, à l'emprise du Droit administratif, sont bien souvent, même pour les contrats de droit privé, différentes de celles du droit commun (...)."
} 
inteira e unicamente a um só regime jurídico (público ou privado). Reiterando que mesmo quando a Administração Pública agir em assuntos típicos de direito privado terá de seguir os preceitos peculiares da lei e a busca do interesse público, Vladimir da Rocha França destaca:

\begin{abstract}
"Deve ser ressaltado, contudo, que a Administração não deixa de ficar submetida a sujeições inteiramente estranhas para o particular, na aplicação do regime jurídico do direito privado. É ilegítima, por exemplo, a demissão de empregado público que foi realizada sem a observância de preceitos caros ao regime jurídico-administrativo, como a motivação, o contraditório e a ampla defesa.

Isso acontece em virtude do princípio da legalidade administrativa, ao submeter ação administrativa ao que for autorizado pela lei. A lei impõe essas limitações à Administração, com intuito de assegurar a indisponibilidade do interesse público e os direitos dos administrado. Noutro giro: nas relações jurídico-privadas que envolvem a Administração, as prerrogativas usualmente reconhecidas aos particulares podem sofrer restrições e condicionamentos para evitar que a gestão do interesse público fique ao inteiro alvedrio do administrador."174
\end{abstract}

Além disso, a Lei Federal de Licitações e Contratos Administrativos (Lei Federal n. ${ }^{\circ}$ 8.666/1993) estabelece cláusulas básicas que devem estar presentes em todos os contratos celebrados pela Administração Pública. Não havendo qualquer ressalva no texto da lei, entende-se que estas devem ser incluídas tanto em contratos regidos pelo direito público quanto pelo direito privado:

\footnotetext{
“Art. 55. São cláusulas necessárias em todo contrato as que estabeleçam:

I - o objeto e seus elementos característicos;

II - o regime de execução ou a forma de fornecimento;

III - o preço e as condições de pagamento, os critérios, data-base e periodicidade do reajustamento de preços, os critérios de atualização monetária entre a data do adimplemento das obrigações e a do efetivo pagamento;
}

IV - os prazos de início de etapas de execução, de conclusão, de entrega, de observação e de recebimento definitivo, conforme o caso;

V - o crédito pelo qual correrá a despesa, com a indicação da classificação funcional programática e da categoria econômica;

\footnotetext{
${ }^{174}$ FRANÇA, Vladimir da Rocha. op. cit., p. 9.
} 
VI - as garantias oferecidas para assegurar sua plena execução, quando exigidas;

VII - os direitos e as responsabilidades das partes, as penalidades cabíveis e os valores das multas;

VIII - os casos de rescisão;

IX - o reconhecimento dos direitos da Administração, em caso de rescisão administrativa prevista no art. 77 desta Lei;

$\mathrm{X}$ - as condições de importação, a data e a taxa de câmbio para conversão, quando for o caso;

XI - a vinculação ao edital de licitação ou ao termo que a dispensou ou a inexigiu, ao convite e à proposta do licitante vencedor;

XII - a legislação aplicável à execução do contrato e especialmente aos casos omissos;

XIII - a obrigação do contratado de manter, durante toda a execução do contrato, em compatibilidade com as obrigações por ele assumidas, todas as condições de habilitação e qualificação exigidas na licitação.

$\S 1^{\circ}$ (Vetado). (Redação dada pela Lei n ${ }^{\circ} 8.883$, de 1994)

$\S 2^{\underline{0}}$ Nos contratos celebrados pela Administração Pública com pessoas físicas ou jurídicas, inclusive aquelas domiciliadas no estrangeiro, deverá constar necessariamente cláusula que declare competente o foro da sede da Administração para dirimir qualquer questão contratual, salvo o disposto no $\S 6^{\circ}$ do art. 32 desta Lei.

$\S 3^{\text {o }}$ No ato da liquidação da despesa, os serviços de contabilidade comunicarão, aos órgãos incumbidos da arrecadação e fiscalização de tributos da União, Estado ou Município, as características e os valores pagos, segundo o disposto no art. 63 da Lei $\mathrm{n}^{\circ} 4.320$, de 17 de março de 1964."

Da leitura de referido dispositivo, é possível notar que os elementos que constam dele encontram-se também presentes do Livro I da Parte Especial ("Do Direito das Obrigações”) do Código Civil brasileiro (Lei Federal n. ${ }^{\circ}$ 10.406/2002).

Assim, por exemplo, "o objeto e seus elementos característicos" determinados pelo inciso I do art. 55 da Lei Federal n. ${ }^{\circ} 8.666 / 1993$ são elementos essenciais também dos contratos privados em geral (incluindo aqueles dos quais a Administração Pública seja 
parte), sendo abordados pelo art. $233^{175}$ (obrigação de dar coisa certa) e pelo art. $243^{176}$ (obrigação de dar coisa incerta) do Código Civil.

Por sua vez, as condições do negócio jurídico listadas pelo art. 55, como o regime de execução e a forma de fornecimento (inciso II); o preço e as condições de pagamento, os critérios, data-base e periodicidade do reajuste de preços, os critérios de atualização monetária entre a data do adimplemento das obrigações e a do efetivo pagamento (inciso III); os prazos aplicáveis (inciso IV); a fonte do pagamento (inciso V); as garantias (inciso VI), direitos, responsabilidade e penalidades (inciso VII); os casos de rescisão (inciso VIII); assim como as condições específicas (condições de importação, taxa de câmbio e legislação aplicável) são igualmente abordados pelo Código Civil como elementos contratuais para formalizar o negócio jurídico.

Esse é, assim, mais um ponto de semelhança entre os contratos administrativos e os contratos privados da Administração Pública.

Da mesma forma, as condições de nulidade e de anulabilidade dos negócios jurídicos estabelecidas pelos artigos 166 e seguintes do Código Civil se aplicam aos contratos celebrados pela Administração Pública, devendo, no entanto, sofrer as devidas adaptações.

Quando o art. $166^{177}$ estabelece, por exemplo, que é nulo o negócio jurídico caso seja celebrado por pessoa incapaz (inciso I), deve-se entender, no caso da Administração Pública, que será nulo quando o órgão da Administração Pública não possuir competência para contratar ou não houver a dotação orçamentária necessária.

Da mesma maneira, quaisquer contratos celebrados pela Administração Pública que tenham objeto ilícito, impossível ou indeterminável (inciso II), apresentarem motivo

\footnotetext{
175“Art. 233. A obrigação de dar coisa certa abrange os acessórios dela embora não mencionados, salvo se o contrário resultar do título ou das circunstâncias do caso."

176“"Art. 243. A coisa incerta será indicada, ao menos, pelo gênero e pela quantidade."

177،Art. 166. É nulo o negócio jurídico quando:

I - celebrado por pessoa absolutamente incapaz;

II - for ilícito, impossível ou indeterminável o seu objeto;

III - o motivo determinante, comum a ambas as partes, for ilícito;

IV - não revestir a forma prescrita em lei;

$\mathrm{V}$ - for preterida alguma solenidade que a lei considere essencial para a sua validade;

VI - tiver por objetivo fraudar lei imperativa;

VII - a lei taxativamente o declarar nulo, ou proibir-lhe a prática, sem cominar sanção.”
} 
determinante comum a ambas as partes ilícito (inciso III); não possuirem a forma prescrita em lei (inciso IV); em que seja suprimida solenidade que a lei considere essencial para a sua validade, tal como a licitação (inciso V); tiverem por objetivo fraudar lei (inciso VI); ou, ainda, que a lei taxativamente declare nulos, ou proiba a prática sem cominar sanção (inciso VII) serão nulos.

As hipóteses de anulabilidade do negócio jurídico trazidas pelo art. 171 do Código Civil (incapacidade relativa e vício de consentimento) seguem o mesmo raciocínio, se aplicando aos contratos celebrados pela Administração Pública:

\footnotetext{
“Art. 171. Além dos casos expressamente declarados na lei, é anulável o negócio jurídico:

I - por incapacidade relativa do agente;

II - por vício resultante de erro, dolo, coação, estado de perigo, lesão ou fraude contra credores.
}

Ora, o negócio jurídico formalizado por meio de um contrato em que a Administração Pública é parte é semelhante a qualquer outro negócio jurídico, resguardadas as peculiaridades da parte administrativa, que é, acima de tudo, um ente de direito público.

Portanto, para que se possa compreender corretamente as semelhanças e diferenças entre os contratos entre entes privados, os contratos administrativos e os contratos privados da Administração Pública, é necessário que se entenda as peculiaridades dos entes públicos e a lógica de seu funcionamento. Asumindo-se estas premissas como ponto de partida do raciocínio, o entendimento certamente será mais lógico para o intérprete. 


\title{
CAPÍTULO III. A LEGISLAÇÃO BRASILEIRA E OS CONTRATOS PRIVADOS DA ADMINISTRAÇÃO PÚBLICA
}

\section{Das regras gerais da Lei de Licitações e Contratos Administrativos brasileira}

Ponto crucial para a razão de ser dete trabalho é o fato de que a celebração de contratos privados pela Administração Pública é prática admitida pela Lei de Licitações e Contratos Administrativos brasileira (Lei Federal n. ${ }^{\circ}$ 8.666/1993 e suas subseqüentes alterações), afirmação esta baseada em diversas passagens de referido diploma legal.

Assim é que referida lei se inicia com o seguinte artigo:

\begin{abstract}
"Art. 1º. Esta Lei estabelece normas gerais sobre licitações e contratos administrativos pertinentes a obras, serviços, inclusive de publicidade, compras, alienações e locações no âmbito dos Poderes da União, dos Estados, do Distrito Federal e dos Municípios.

Parágrafo único. Subordinam-se ao regime desta Lei, além dos órgãos da administração direta, os fundos especiais, as autarquias, as fundações públicas, as empresas públicas, as sociedades de economia mista e demais entidades controladas direta ou indiretamente pela União, Estados, Distrito Federal e Municípios."
\end{abstract}

Percebe-se através da leitura do caput de referido dispositivo que não há exclusão expressa de outras normas no campo das licitações e contratos administrativos, pelo que se subentende que podem ser aplicados institutos próprios do direito privado a tal matéria. Dessa forma, o direito privado, a exemplo de todo o restante da legislação pátria, é aplicado aos contratos da Administração Pública quando houver compatibilidade com o direito público ${ }^{178}$.

No entanto, importa ressaltar, para evitar dúvidas e confusões por parte do intérprete, que a Lei Federal n. ${ }^{\circ}$ 8.666/1993, apesar de admitir os contratos civis da

\footnotetext{
${ }^{178}$ Essa é a opinião de Marçal Justen Filho, em sua obra Comentários à Lei de Licitações e Contratos Administrativos. 7. ed., cit., p. 14, a qual reputamos amplamente abalizada.
} 
Administração ${ }^{179}$, tanto no art. $1^{\circ}$ supra quanto no art. $54^{180}$ coloca a eles a denominação de "contratos administrativos" indistintamente para todos aqueles contratos abordados por $\mathrm{ela}^{181}$.

Há, portanto, um equívoco de nomenclatura que acaba por causar grande confusão na diferenciação entre os contratos regidos predominantemente pelo direito privado e aqueles em que prevalesce o direito público, pois, caso alguém decidisse seguir a nomenclatura única empregada no texto legislativo, acabaria se referindo pelo mesmo nome ("contrato administrativo") a ambas as modalidades de contrato da Administração Pública.

Parte da doutrina, fazendo uma leitura não interpretativa do dispositivo, acaba por afirmar não existirem os chamados "contratos privados da Administração Pública”, como observa Vladimir da Rocha França ${ }^{182}$ :

“A Lei Federal n. ${ }^{\circ} 8.666 / 1993$ chega, no parágrafo único do art. 2ª definir contrato, para os fins de sua incidência, como 'todo e qualquer ajuste entre órgãos ou entidades da Administração Pública e particulares, em que haja um acordo de vontade para a formação de vínculo e a estipulação de obrigações recíprocas, seja qual for a denominação utilizada'. Mais à frente, esse diploma legal torna aparentemente difícil o acolhimento da doutrina que classifica essas avencas em contratos de direito privado da Administracão e contratos administrativos:

(i) ao estabelecer que os contratos administrativos 'regulam-se pelas cláusulas e pelos preceitos de direito público, aplicando-se-lhes, supletivamente, os princípios da teoria geral dos contratos $\mathrm{e}$ as disposições de direito privado' (art. 54); e,

\footnotetext{
${ }^{179} \mathrm{O}$ que, portanto, deveria fazer com que a referência cotidiana a ela fosse, em tese, "Lei Federal de Licitações e Contratos da Administração Pública", ao invés do corriqueiro "Lei Federal de Licitações e e Contratos Administrativos". No entanto, tendo em vista a já altamente difundida e popular referência a esta nomenclatura, inclusive junto à mais abalisada doutrina e jurisprudência, manteremos bo presente trabalho a sua utilização.

180، Art. 54. Os contratos administrativos de que trata esta Lei regulam-se pelas suas cláusulas e pelos preceitos de direito público, aplicando-se-lhes, supletivamente, os princípios da teoria geral dos contratos e as disposições de direito privado.

$\S 1^{\circ}$ Os contratos devem estabelecer com clareza e precisão as condições para sua execução, expressas em cláusulas que definam os direitos, obrigações e responsabilidades das partes, em conformidade com os termos da licitação e da proposta a que se vinculam.

$\S 2^{\underline{0}}$ Os contratos decorrentes de dispensa ou de inexigibilidade de licitação devem atender aos termos do ato que os autorizou e da respectiva proposta."

${ }^{181}$ Chama a atenção nesse sentido Hely Lopes Meirelles, Licitação e contrato administrativo. 13. ed. São Paulo: Malheiros Ed., 2002. p. 184 (“A própria Lei 8.666, de 1993 (arts. $1^{\circ}$ e 54), denomina como administrativos todos os contratos por ela regulados, e é evidente que nem todos têm essa natureza, como os ajustes relativos a compra e venda, alienação, seguro, financiamento e concessão de direito real de uso").

${ }^{182}$ FRANÇA, Vladimir da Rocha. op. cit., p. 6-7.
} 
(ii) ao determinar a aplicação de determinadas çláusulas exorbitantes’ para os 'contratos de seguro, de financiamento, de locação em que o Poder Público seja locatário, e aos demais cujo conteúdo seja regido, predominantemente, por norma de direito privado' e para os çontratos em que a Administração for parte como usuária de serviço público' (art. 65, $\left.\S 3^{\circ}\right)$." (destacamos)

Contudo, como dissemos, estenão é o nosso entendimento. Confirmando o que já havíamos observado por ocasião do comentário ao art. $1^{\circ}$ da Lei, vem o art. $2^{\circ}$ confirmar o entendimento de que o diploma legal se refere às duas modalidades de contratos da Administração Pública e que o uso inadvertidamente da mesma nomeclatura para ambas foi um mero discuido do legislador.

$\mathrm{O}$ art. $2^{\circ}$ da Lei define "contrato", em seu parágrafo único, como "todo e qualquer ajuste entre órgãos ou entidades da Administração Pública e particulares, em que haja um acordo de vontades para a formação de vínculo e a estipulação de obrigações recíprocas, seja qual for a denominacão utilizada" (destacamos):

\footnotetext{
"Art. $2^{\circ}$. As obras, serviços, inclusive de publicidade, compras, alienações, concessões, permissões e locações da Administração Pública, quando contratadas com terceiros, serão necessariamente precedidas de licitação, ressalvadas as hipóteses previstas nesta Lei.

Parágrafo único. Para os fins desta Lei, considera-se contrato todo e qualquer ajuste entre órgãos ou entidades da Administração Pública e particulares, em que haja um acordo de vontades para a formação de vínculo e a estipulação de obrigações recíprocas, seja qual for a denominação utilizada."
}

Como se percebe, enquanto o caput do artigo citado abrange expressamente diversas formas de contratação da Administração Pública, inclusive aquelas notadamente privadas (compras, alienações e locações), o parágrafo único acaba com qualquer dúvida que eventualmente ainda possa pairar sobre tal admissibilidade no direito pátrio, uma vez que fornece conceito amplo do que se entende por "contrato" para efeitos da Lei.

Se para a Lei deve-se considerar contrato todo e qualquer ajuste entre órgãos ou entidades da Administração Pública e particulares, por evidente que ela aceita os contratos de natureza civil celebrados pela Administração Pública. Mais do que isso, o 
instrumento em questão nem mesmo precisa receber a denominação de contrato para que seja classificado como tal.

Por outro lado, como aponta Marçal Justen Filho ${ }^{183}$, há inexatidão da definição fornecida pelo legislador ao inserir a existência de "obrigações recíprocas" como requisito para a configuração de contrato na definição fornecida pelo parágrafo único do art. $2^{\circ}$ supra, pois há contratos que podem estabelcer apenas obrigações unilaterais, como, por exemplo, a doação ${ }^{184}$.

\section{Da redação dos contratos da Administração Pública conforme a lei}

Por oportuno, é de se notar que as críticas feitas por parte da doutrina, encabeçada por Oswaldo Aranha Bandeira de Mello e Celso Antônio Bandeira de Mello, no sentido de que os ajustes na seara administrativa não consubstanciariam verdadeiramente "contratos" carecem de aplicação prática no direito pátrio, eis que o legislador considera contrato "todo e qualquer ajuste entre órgãos ou entidades da Administração Pública e particulares, em que haja um acordo de vontades para a formação de vínculo e a estipulação de obrigações recíprocas" (parágrafo único do art. $2^{\circ}$ da Lei supracitada).

Muito embora os instrumentos celebrados pela Administração Pública para formalizar suas avenças muitas vezes não sejam idênticos àqueles celebrados pelos particulares, ainda assim os elementos caracterizadores de um contrato, estipulados pela doutrina civilista de modo geral, se encontram efetivamente presentes, razão pela qual acreditamos que a terminologia "contrato" é correta mesmo para a as avenças públicas.

Este fato é exposto com maestria por Edmir Netto de Araújo:

"O acordo (obviamente de duas ou mais pessoas), no contrato, para produzir obrigações, é de vontades opostas: em uma obra de engenharia, por exemplo, um quer a obra, e o outro o preço para construí-la; tal não ocorre nos convênios ou consórcios, em que as vontades são comuns ou coincidentes.

\footnotetext{
${ }^{183}$ JUSTEN FILHO, Marçal. Comentários à Lei de Licitações e Contratos Administrativos. 9. ed., cit., p. 42.

${ }^{184}$ Muito embora exista quem defenda que a doação sempre denota obrigação da outra parte, que é a de receber o objeto da doação, sem mencionar os casos de doação condicionada.
} 
Além disso, tais vontades devem ser livremente (e validamente) manifestadas, o que pressupõe pessoas que tenham capacidade jurídica para fazê-lo. Essa liberdade é a de contrair ou não o vínculo contratual, nas condições convencionadas ou propostas.

Por outro lado, ninguém contrata para não cumprir o que convencionou, portanto a relação livremente eleita pelas partes as subjuga (pacta sunt servanda), caso contrário nem se justificaria acordo de vontades sobre o objeto.

Finalmente, são características de categoria contratual, ainda, aquelas ditadas pela ordem pública, inclusive quanto à licitude do objeto e à obediência à forma, esta mais em defesa da estabilidade e da confiabilidade das relações jurídicas."

Examinando-se o diploma regente das licitações e contratos da Administração Pública, percebe-se que ele não traz disciplina específica para qualquer tipo de contrato privado da Administração Pública. Assim, contratos como os de compra e venda, doação, locação ou contratação de seguro, por exemplo, quando celebrados pela Administração Pública, deverão seguir o disposto no caput do art. 54, aplicando-se a eles "supletivamente, os princípios da teoria geral dos contratos e as disposições de direito privado".

Da mesma forma, o legislador não procurou enfrentar a tarefa de legitimar a adoção de quaisquer critérios diferenciadores das modalidades de contratos da Administração Pública, relegando este desafio apenas ao intérprete.

Por força do já citado art. 54, grande parte das cláusulas a serem inseridas nos contratos privados da Administração Pública virão do Código Civil ou de legislação específica (como, por exemplo, a lei de locação para fins não residenciais). No entanto, os mandamentos da legislação privada deverão ser complementados por alguns dispositivos da Lei Federal n. ${ }^{\circ} 8.666 / 1993$, nos termos do art. $62, \S 3^{\circ}$, I:

"Art. 62. O instrumento de contrato é obrigatório nos casos de concorrência e de tomada de preços, bem como nas dispensas e inexigibilidades cujos preços estejam compreendidos nos limites destas duas modalidades de licitação, e facultativo nos demais em que a Administração puder substituí-lo por outros instrumentos hábeis, tais

\footnotetext{
${ }^{185}$ ARAÚJO, Edmir Netto de. Curso de direito administrativo. 4. ed., cit., p. 626-627, grifos no original. Trata-se de idéia que já fora anteriormente defendida pelo Autor em suas obras Contrato administrativo. São Paulo: Ed. Revista dos Tribunais, 1987. p. 12-15 e Do negócio jurídico administrativo. São Paulo: Ed. Revista dos Tribunais, 1992. p. 119-120. Originalmente apresentada como tese de titular à Faculdade de Direito da USP em 1991.
} 
como carta-contrato, nota de empenho de despesa, autorização de compra ou ordem de execução de serviço.

(...) $\S 3^{\circ}$ Aplica-se o disposto nos arts. 55 e 58 a 61 desta Lei e demais
normas gerais, no que couber:

I - aos contratos de seguro, de financiamento, de locação em que o Poder Público seja locatário, e aos demais cujo conteúdo seja regido, predominantemente, por norma de direito privado;

II - aos contratos em que a Administração for parte como usuária de serviço público. (...)" (destacamos)

Segundo o $\$ 3^{\circ}$ do art. $62^{186}$, certas características do regime de direito público aplicam-se mesmo àqueles contratos de características predominantemente civis celebrados pela Administração Pública ${ }^{187}$. Além disso, como coloca o texto de tal dispositivo (estabelece que aos contratos de direito privado celebrados pela Administração aplicam-se os arts. 55 - cláusulas obrigatórias dos contratos, 58 - essência do regime jurídico especial, 59 - nulidades contratuais, 60 - formalidades contratuais da Administração Pública, complementadas pelo art. 61, igualmente aplicável ${ }^{188}$ ), os mandamentos do art. 56 da lei (exigência de garantia) e do art. 57 (prazos) não se aplicam aos contratos civis da Administração, ficando, portanto, a cargo do direito privado regular o fornecimento de garantias e os prazos contratuais máximos.

\footnotetext{
${ }^{186} \mathrm{E}$ pertinente a este tema a lição de Vladimir de Rocha França: "Os contratos de direito privado da Administração são subordinados aos preceitos do regime jurídico de direito privado que sejam compatíveis com o regime jurídico-administrativo. $O$ conteúdo desses pactos é regido predominantemente por normas de direito privado, embora o ordenamento jurídico imponha limitaçães à Administração que somente orbigariam os particulares se estes assim consentissem.

Ao empregar a expressão 'no que couber' o art. $65, \xi^{\circ}$ [sic, na verdade, quis o Autor se referir ao art. 62, $\S 3^{\circ}$ ], da Lei Federal $n .^{\circ} 8.666 / 1993$, o ordenamento jurídico confere à Administração a prerrogativa de apreciar a conveniência e a oportunidade do emprego de algumas cláusulas exorbitantes nos contratos de direito privado da Ad,ministração. $O$ que demanda, por conseguinte, previsão contratual para a sua admissibilidade." (FRANÇA, Vladimir da Rocha. op. cit., p. 9).

${ }^{187}$ Assim é a observação de Maria Sylvia Zanella Di Pietro em seu Temas polêmicos sobre licitações $e$ contratos. 5. ed. São Paulo: Malheiros Ed., 2001. p. 304.

Marçal Justen Filho acredita que a previsão do $\$ 3^{\circ}$ está mal localizada dentro do texto legal e ficaria melhor esse colocada em dispositivo específico, por não ter uma relação com o restante do artigo (JUSTEN FILHO, Marçal. Comentários à Lei de Licitações e Contratos Administrativos. 9. ed., cit., p. 489).

${ }^{188}$ Para Alice Gonzalez Borges, numa análise que parte do ponto de vista dos contratos de locação celebrados pela Administração Pública, essa "enumeração de dispositivos sobre os contratos, a lei não inclui alguns muito importantes, quais sejam: o art. 56, relativo às garantias contratuais, e o art. 57, que diz respeito à duração dos ajustes, parecendo querer, deliberadamente, submetê-los à égide da legislação civil" (BORGES, Alice Gonzalez. A administração pública como locatária, cit., p. 232).
} 
Há, assim, uma mistura de cláusulas oriundas da legislação civil e da Lei Federal de Licitações e Contratos Administrativos em todo e qualquer contrato que o Poder Público celebra (incluindo aí, portanto, mesmo os contratos privados da Administração Pública). Esta mistura resulta no fato de que, muito embora exista sempre um regime jurídico (público ou privado) predominante, não se pode cogitar defender a total e completa regência de apenas um deles ${ }^{189}$.

Reconhecendo a mescla de regimes jurídicos, José Roberto Dromi, inclusive, critica o uso da nomenclatura "contratos privados da Administração Pública", pois, para referido Autor, a lógica seria a mesma dos "atos privados da Administração Pública": sendo apenas parcialmente regidos pelo direito privado, não poderiam ser chamados de "privados" com propriedade $^{190}$.

Todavia, o $\$ 3^{\circ}$ do art. 62 supra transcrito causa confusão ao fazer referência às “demais normas gerais", posto que o art. $1^{\circ}$ desta mesma lei - igualmente transcrito acima - deixa claro que "[e]sta Lei estabelece normas gerais sobre licitações e contratos administrativos", de maneira que todos os dispositivos deste diploma, portanto, podem ao menos em tese - ser considerados normas gerais.

Ademais, a linguagem empregada pelo legislador no $\S 3^{\circ}$ do art. 62 deixa a cargo do intérprete quais normas se aplicam aos contratos regidos predominantemente pelo direito privado, eis que a expressão "no que couber" não estabelece previamente de maneira objetiva quais são as regras que devem prevalecer.

Por sua vez, o art. 55 dessa mesma Lei Federal n. ${ }^{\circ}$ 8.666/1993, expressamente elencado pelo art. 62 supra como aplicável aos contratos predominantemente regidos pelo direito privado, coloca as cláusulas necessárias a todo e qualquer contrato celebrado pela Administração, não fazendo qualquer forma de distinção quanto à sua natureza:

\footnotetext{
${ }^{189}$ Nesse sentido, ver FURTADO, Lucas Rocha. Curso de direito administrativo. Belo Horizonte: Forum, 2007. p. 56.

190“El criterio a adoptar en cuanto a los contractos privados de la Administración es el mismo que el de la supuesta existencia de los actos privados de la Administración.

Si bien en determinados casos se aplica el Derecho privado al objeto o contenido del acto, o la relación jurídica emergente, ello no justifica sostener que tal acto sea privado, pues siempre habrán de regirse por el Derecho público los demás elementos, como competencia, voluntad, motivación, forma, causa, etcétera." (DROMI, Roberto. Derecho administrativo. 10. ed. Buenos Aires: Editorial Ciudad Argentina, 2004. p. 473).
} 
“Art. 55. São cláusulas necessárias em todo contrato as que estabeleçam:

I - o objeto e seus elementos característicos;

II - o regime de execução ou a forma de fornecimento;

III - o preço e as condições de pagamento, os critérios, data-base e periodicidade do reajustamento de preços, os critérios de atualização monetária entre a data do adimplemento das obrigações e a do efetivo pagamento;

IV - os prazos de início de etapas de execução, de conclusão, de entrega, de observação e de recebimento definitivo, conforme o caso;

V - o crédito pelo qual correrá a despesa, com a indicação da classificação funcional programática e da categoria econômica;

VI - as garantias oferecidas para assegurar sua plena execução, quando exigidas;

VII - os direitos e as responsabilidades das partes, as penalidades cabíveis e os valores das multas;

VIII - os casos de rescisão;

IX - o reconhecimento dos direitos da Administração, em caso de rescisão administrativa prevista no art. 77 desta Lei;

$\mathrm{X}$ - as condições de importação, a data e a taxa de câmbio para conversão, quando for o caso;

XI - a vinculação ao edital de licitação ou ao termo que a dispensou ou a inexigiu, ao convite e à proposta do licitante vencedor;

XII - a legislação aplicável à execução do contrato e especialmente aos casos omissos;

XIII - a obrigação do contratado de manter, durante toda a execução do contrato, em compatibilidade com as obrigações por ele assumidas, todas as condições de habilitação e qualificação exigidas na licitação.

\section{$\S 1^{\circ}($ VETADO $)$}

$\S 2^{\underline{0}}$ Nos contratos celebrados pela Administração Pública com pessoas físicas ou jurídicas, inclusive aquelas domiciliadas no estrangeiro, deverá constar necessariamente cláusula que declare competente o foro da sede da Administração para dirimir qualquer questão contratual, salvo o disposto no $\S 6^{\circ}$ do art. 32 desta Lei.

$\S 3^{\text {o }}$ No ato da liquidação da despesa, os serviços de contabilidade comunicarão, aos órgãos incumbidos da arrecadação e fiscalização de tributos da União, Estado ou Município, as características e os valores pagos, segundo o disposto no art. 63 da Lei no 4.320 , de 17 de março de 1964." 
O dispositivo transcrito enumera cláusulas importantes e aplicáveis ordinariamente a qualquer modalidade de contratação, com a única diferença de que nos casos em que a Administração Pública seja parte, tais cláusulas se tornam obrigatórias ${ }^{191}$.

Segundo Toshio Mukai ${ }^{192}$,

"Cláusula é condição imposta no contrato pelas partes, regendo as relações recíprocas entre elas, a respeito do objeto contratual. As cláusulas necessárias do contrato administrativo visam ao resguardo do interesse público, razão por que muitas delas são consideradas exorbitantes, não devendo constar de um contrato entre particulares, sob pena de torná-lo 'leonino' em relação à parte que se encontrar desfavorecida com sua inserção."

Não havendo distinção quanto a modalidades de contratação e/ou regimes jurídicos contratuais, entende-se que estas cláusulas são obrigatórias a todo e qualquer contrato do qual o Poder Público seja parte, o que tornaria dispensável sua menção expressa pelo art. 62 (até por conta da referência expressa às "demais normas gerais" que já consta deste mesmo dispositivo).

Tal enumeração não se equipara àquela efetuada por meio do art. $58^{193}$ da mesma lei, posto que este dispositivo se refere às chamadas "cláusulas exorbitantes" (também denominadas “cláusulas de privilégio", "cláusulas de prerrogativas" ou "cláusulas derrogativas").

Essas cláusulas, usualmente classificadas pela doutrina como características dos contratos regidos pelo direito público - porquanto estabelecem prerrogativas que somente se justificariam sob o regime jurídico público e, assim, seriam "exorbitantes" ou “derrogatórias" do direito comum - não seriam, a princípio, passíveis de inserção obrigatória em contratos "cujo conteúdo seja regido, predominantemente, por norma de direito privado":

\footnotetext{
${ }^{191}$ Cabe notar, no entanto, que a lei silencia a respeito dos efeitos advindos da falta de uma delas.

${ }^{192}$ MUKAI, Toshio. Licitações e contratos públicos. 5. ed. São Paulo: Saraiva, 1999. p. 90, nota 36.

${ }^{193}$ Interessante a lição de Diogo de Figueiredo Moreira Neto, que divide as cláusulas exoritantes em três classes: cláusulas exorbitantes de executoriedade (art. 58, II, III, IV e V da Lei Federal n. ${ }^{\circ}$ 8.666/1993); cláusulas exorbitantes de jus variandi (art. 58, I da Lei Federal n. ${ }^{\circ}$ 8.666/1993); e cláusulas exorbitantes de efeitos sobre terceiros (art. 31, VI da Lei Federal n. ${ }^{\circ}$ 8.987/1995). Conforme MOREIRA NETO, Diogo de Figueiredo. O futuro das cláusulas exorbitantes nos contratos administrativos. In: ARAGÃO, Alexandre Santos de, MARQUES NETO, Floriano de Azevedo (Coords.), cit., p. 580-581 e p. 587.
} 
"Art. 58. O regime jurídico dos contratos administrativos instituído por esta Lei confere à Administração, em relação a eles, a prerrogativa de:

I - modificá-los, unilateralmente, para melhor adequação às finalidades de interesse público, respeitados os direitos do contratado;

II - rescindi-los, unilateralmente, nos casos especificados no inciso I do art. 79 desta Lei;

III - fiscalizar-lhes a execução;

IV - aplicar sanções motivadas pela inexecução total ou parcial do ajuste;

V - nos casos de serviços essenciais, ocupar provisoriamente bens móveis, imóveis, pessoal e serviços vinculados ao objeto do contrato, na hipótese da necessidade de acautelar apuração administrativa de faltas contratuais pelo contratado, bem como na hipótese de rescisão do contrato administrativo.

$\S 1^{0}$ As cláusulas econômico-financeiras e monetárias dos contratos administrativos não poderão ser alteradas sem prévia concordância do contratado.

$\S 2^{\underline{0}} \mathrm{Na}$ hipótese do inciso I deste artigo, as cláusulas econômicofinanceiras do contrato deverão ser revistas para que se mantenha o equilíbrio contratual."

Para a aplicação do art. 58 aos contratos privados da Administração Pública, há necessariamente que se proceder com um prévio juízo crítico de seu conteúdo. Itens como a prerrogativa de modificação unilateral para melhor adequação às finalidades de interesse público (inciso I do art. 58) não seriam, prima facie, compatíveis com contratos civis ${ }^{194}$, tais como os de seguro, de financiamento, de locação em que o Poder Público seja locatário etc., pois estes contratos, tipicamente ligados a interesses da Administração Pública enquanto pessoa jurídica, não envolvem diretamente finalidades de interesse público, e é justamente a presença destas finalidades que justificariam a presença de uma prerrogativa extraordinária como a de modificação unilateral.

\footnotetext{
${ }^{194}$ Nesse sentido, Marçal Justen Filho, Comentários à Lei de Licitações e Contratos Administrativos. 9. ed., cit., p. 490. Destaque-se: "O elenco do art. $58, \S 3^{\circ}$, inc. I, apresenta evidente natureza exemplificativa. As referências ali contidas devem ser consideradas como um padrão para identificação de outras espécies contratuais similares, que não poderão perder suas características inerentes de natureza privada. (...) $\mathrm{O}$ art. 58 sintetiza faculdades inconciliáveis com os princípios do direito privado. As peculiaridades dos contratos administrativos residem grandemente nas prerrogativas unilaterais asseguradas à Administração Pública. Em se tratando de contratos típicos do direito privado, deve-se assegurar ao particular a opção entre o restabelecimento do equilíbrio econômico-financeiro do contrato e a rescisão do contrato".
} 
Da mesma forma, a prerrogativa de rescisão unilateral estabelecida no inciso II do artigo não é característica de negócio jurídico privado e somente em casos como aqueles descritos pelo inciso I do art. 79 do mesmo diploma legal seriam aceitáveis.

O inciso IV estabelece a possibilidade de a Administração Pública aplicar sanções motivadas em vista da inexecução parcial ou total do ajuste pelo particular. Esta é outra prerrogativa que somente se justificaria, em tese, em contexto no qual uma das partes do contrato possua motivo ligado a interesse público, para agir sob a égide do direito público $^{195}$.

Todavia, o art. 58 é, na verdade, a comprovação daquilo que já tivemos a oportunidade de observar anteriormente: que, uma vez demonstrada a presença de interesse público, poderá haver exercício de prerrogativa pública mesmo nos contratos privados da Administração.

$\mathrm{O}$ art. 58 traz, ainda, outros dispositivos relevantes para o ente privado que contrata com a Administração Pública, tais como a necessidade de respeitar os direitos do contratado (inciso I) e a necessidade de anuência prévia do contratado para alteração das cláusulas econômico-financeiras e monetárias $\left(\S 1^{\circ}\right)$ e manutenção do equilíbrio econômico-financeiro do contrato $\left(\$ 2^{\circ}\right)$. Além disso, há no art. 58 , ainda, a prerrogativa do Poder Público de fiscalizar a execução (inciso III), que muito se assemelha a qualquer contrato privado de objeto semelhante.

Para a aplicação do art. 58 aos contratos privados da Administração, portanto, há necessariamente que se proceder com um prévio juízo crítico de seu conteúdo. Tendo em vista a presunção de que o legislador não emprega palavras em vão, cabe então o entendimento de que a expressão "no que couber" presente no art. 62 da lei se refere justamente à necessidade de avaliar o grau de predominância do direito privado sobre cada contrato avençado pelo Poder Público, para que se possa verificar quais das prerrogativas elencadas pelo art. 58 seriam compatíveis com a natureza jurídica do instrumento, pois o art. 62 fala apenas em contratos regidos predominantemente pelo direito privado, e não em

\footnotetext{
${ }^{195}$ Nesse sentido, Edmir Netto de Araújo leciona que "essa é uma das notas características do contrato administrativo: ser parte a Administração. Todavia, não basta isso, ela deve colocar-se em posição de supremacia e preponderância na relação contratual, ao contrário da pda paridade e equivalência de vontades inerentes aos ajustes privados." (ARAÚJO, Edmir Netto de. Curso de direito administrativo. 4. ed., cit., p. 643).
} 
total regência por referido regime. Itens como a modificação unilateral e a aplicação são, pelo critério da razoabilidade e frente ao Direito Privado pátrio, inaceitáveis no bojo de contrato puramente civil ${ }^{196}$, mas cabíveis em contratos de regime parcialmente misto, como o são os contratos administrativos e os contratos privados da Administração Pública.

Percebe-se, assim, o papel de relevo da análise perfilada no presente trabalho e, acima de tudo, realizada pelo intérprete da legislação e pelo aplicador magistrado, responsáveis pela aplicação da legislação, posto que a linguagem empregada pelo legislador não é unívoca, conclamando a necessidade de atividade interpretativa.

Como efeito, os contratos privados da Administração Pública são efetivamente aceitos pela lei brasileira de licitações e contratos administrativos (Lei Federal n. ${ }^{\circ}$ 8.666/1993), mas é necessário reiterar que tais contratos não se igualam pura e simplesmente aos contratos privados celebrados entre particulares: certas adequações precisam ser efetuadas, adequações essas compatíveis às peculiaridades de um ente público, pois seria inadequado simplesmente equiparar a Administração Pública ao particular administrado.

Não se trata de lhe conferir privilégios despropositados e inadequados a um contrato de expediente civil, mas sim de reconhecer as inocultáveis peculiaridades da personalidade pública. Por óbvio que essa é uma tarefa árdua, que deve ser conduzida com a cautela necessária, sob pena de se desfigurar um contrato típico do direito privado e, conseqüentemente, ferir-se de maneira fatal alguns direitos do particular.

Sobre o assunto, ensina Marçal Justen Filho:

\begin{abstract}
"Deve reputar-se que os particulares, em contratações disciplinadas preponderantemente pelo direito privado, não se encontram assujeitados aos poderes excepcionais garantidos à Administração Pública. Ser-lhes-á facultado atender ou não ao pleito da entidade administrativa. Em caso de recusa, a contratação poderá ser extinta" ${ }^{197}$.
\end{abstract}

\footnotetext{
${ }^{196}$ Nesse sentido, Marçal Justen Filho, Comentários à Lei de Licitações e Contratos Administrativos. 9. ed.,

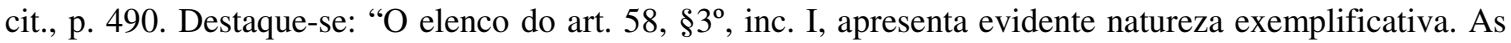
referências ali contidas devem ser consideradas como um padrão para identificação de outras espécies contratuais similares, que não poderão perder suas características inerentes de natureza privada. (...) $\mathrm{O}$ art. 58 sintetiza faculdades inconciliáveis com os princípios do direito privado. As peculiaridades dos contratos administrativos residem grandemente nas prerrogativas unilaterais asseguradas à Administração Pública. Em se tratando de contratos típicos do direito privado, deve-se assegurar ao particular a opção entre o restabelecimento do equilíbrio econômico-financeiro do contrato e a rescisão do contrato".

${ }^{197}$ JUSTEN FILHO, Marçal. Comentários à Lei de Licitações e Contratos Administrativos. 9. ed., cit., 490.
} 
Como já tivemos a oportunidade de ressaltar no presente trabalho, se os direitos dos particulares não forem preservados pelos contratos, corre-se o grande risco de tirar qualquer atratividade da contratação com a Administração Pública.

Assim, embora quase todos os casos de contratos de natureza civil celebrados pela Administração Pública dependam de licitação prévia, empenho de verbas públicas e outros institutos regulados pelo direito público, tais características não chegam (ou ao menos, em tese, não deveriam chegar) a desnaturar a natureza privada do instrumento contratual.

Outra questão relevante que deve necessariamente ser abordada é o confronto entre regras do direito público com regras do direito privado, quando se tratar de um contrato tipicamente regulado pelo Direito Civil. Marçal Justen Filho acredita que "o conflito entre regras de direito privado e de direito público resolve-se em favor dessas últimas. Aplicamse os princípios de direito privado na medida em que sejam compatíveis com o regime de direito público".

Sobre a questão, nossa opinião é a de que o jurista deve procurar conciliar os princípios aplicáveis, mas nos casos em que isso for efetivamente impossível, o interesse público (primário, uma vez que o secundário ficaria no mesmo patamar do interesse do ente privado) deve ser privilegiado pela aplicação do direito público. Tal interesse público, de caráter absolutamente indisponível, seria representado pela necessidade de conservação das características fundamentais do ente público, e somente nesses casos deve imperar o direito público sobre o privado nos contratos ditos "civis" da Administração.

Assim, não se pode afirmar pura e simplesmente que uma prerrogativa pública deve sempre ser aplicada a um contrato da Administração Pública. No caso de um contrato regido predominantemente pelo direito privado, os princípios de direito público somente serão aplicados quando se verificar comprovadamente a presença de interesse público, a justificar a aplicação do regime jurídico público.

Nesse sentido, José Manuel Sérvulo Correia consegue descrever com maestria a razão da possibilidade extraordinária de aplicação de prerrogativas públicas nos contratos privados da Administração Pública: 
"[O interesse público não é nem mesmo] aconselhável como elemento caracterizador do Direito Administrativo, visto que, quando a Administração Pública utiliza meios de Direito privado, é ainda o interesse público a guiá-la." 198

Assim, como se pode perceber, nossa opinião, na contramão de parte dos autores contemporâneos que defende a relativização do princípio da supremacia do interesse público, é a de que ainda hoje é a defesa do interesse público que movimenta toda ação administrativa e, mais do que isto, legitima a razão de ser da própria Administração Pública.

${ }^{198}$ CORREIA, José Manuel Sérvulo. Os princípios constitucionais da administração pública. In: MIRANDA, Jorge (Coord.). Estudos sobre a Constituição. 2. ed. Lisboa: Livraria Petrony, 1979. v. 3, p. 662. 


\section{CAPÍTULO IV. AS LIÇÕES ADVINDAS DA JURISPRUDÊNCIA}

\section{Introdução}

O presente estudo jamais traria uma abordagem abrangente dos contratos privados da Administração Pública sem uma análise do trabalho realizado pelo Poder Judiciário brasileiro no controle exercido sobre a Administração Pública nos casos que envolvem celebração de contratos de direito privado pelo Poder Público.

A celebração de contratos não era tarefa que integrava o cotidiano da Administração Pública com grande frequência até o início do século XX. Isto porque a vasta estrutura que possuía, aliada aos poderes de império o tornavam auto-suficente em grande parte de suas necessidades, sendo as demais atendidas em grande parte por meio de autoritarismo.

O contrato, figura de pacificação social resultante do paralelismo de interesses, portanto, não se mostrava como instrumento que lhe interessasse, pois numa realidade de promoção dos interesses do Estado enquanto pessoa jurídica e na qual tudo possuía ou poderia tomar, não havia razão para transigir.

Mesmo com o surgimento da necessidade de buscar por vias negociais o suprimento de necessidades inatendidas, já no início do século $\mathrm{XX}$, há registros de resistência à figuração do Estado como parte de um contrato ${ }^{199}$, até por conta da herança mesquinha e autosuficiente de outrora.

Parte da doutrina ${ }^{200}$ chega, inclusive, a defender que a herança histórica da atuação administrativa durante o período de absolutismo é responsável pela introdução das cláusulas de prerrogativas nos contratos administrativos (opinião esta da qual discordamos, pois as prerrogativas administrativas advêm da natureza jurídica da Administração Pública, que é inegavelmente distinta da dos entes privados e que a coloca no papel de defensora da

\footnotetext{
${ }^{199}$ Nesse sentido, MEDAUAR, Odete. Direito administrativo moderno. 13. ed. São Paulo: Ed. Revista dos Tribunais, 2009. p. 212.

${ }^{200} \mathrm{Na}$ qual se insere Maria João Estorninho, ao colocar os contratos administrativos como "atos de autoridade" (ESTORNINHO, Maria João. Réquiem pelo contrato administrativo, cit., p. 37).
} 
coletividade, disto decorrendo a possibilidade de utilização de determinados poderes e direitos peculiares).

Acompanhando tal movimento de pacificação da convivência entre administrados e Administração Pública - representado pela transição dos administrados do papel de espectadores do agir administrativo ou de objeto da ação unilateral administrativa para o papel de copartícipe de negócio jurídico ${ }^{201}$-, veio também a regulamentação do método de formação dos contratos, resultando na criação dos procedimentos licitatórios modernos.

Pois bem. Para policiar o correto cumprimento de seus deveres, não só é possível que a Administração Pública realize sua autotutela, invalidando os atos ilegais ou revogando os atos legais, como prevê a Súmula n. ${ }^{\circ} 473$ do Supremo Tribunal Federal (STF):

"Súmula 473 - A Administração pode anular seus próprios atos, quando eivados de vícios que os tornem ilegais, porque deles não se originam direitos, ou revogá-los, por motivo de conveniência e oportunidade, respeitados os direitos adquiridos e ressalvada, em todos os casos, a apreciação judicial."

O autocontrole da Administração Pública é decorrência do dever de observância do princípio da legalidade restrita, em conjunto com a autoexecutoriedade das decisões administrativas. Ora, se a Administração Pública celebra um contrato ilegal, este deve ser anulado. Isto é confirmado pelo teor do art. $49^{202}$ da Lei Federal n. ${ }^{\circ} 8.666 / 1993$, que, muito embora se refira à anulação do procedimento licitatório, quando interpretado em conjunto

\footnotetext{
${ }^{201}$ A qual, num momento ainda posterior, evolui para viabilizar efetivas transações entre Administração Pública e entes privados, como em matéria punitiva e na resolução de conflitos por meios alternativos, por exemplo.

202،Art. 49. A autoridade competente para a aprovação do procedimento somente poderá revogar a licitação por razões de interesse público decorrente de fato superveniente devidamente comprovado, pertinente e suficiente para justificar tal conduta, devendo anulá-la por ilegalidade, de ofício ou por provocação de terceiros, mediante parecer escrito e devidamente fundamentado.

$\S 1^{\underline{o}}$ A anulação do procedimento licitatório por motivo de ilegalidade não gera obrigação de indenizar, ressalvado o disposto no parágrafo único do art. 59 desta Lei.

$\S 2^{\mathrm{o}}$ A nulidade do procedimento licitatório induz à do contrato, ressalvado o disposto no parágrafo único do art. 59 desta Lei.

$\S 3^{0}$ No caso de desfazimento do processo licitatório, fica assegurado o contraditório e a ampla defesa. $\S 4^{\mathrm{o}} \mathrm{O}$ disposto neste artigo e seus parágrafos aplica-se aos atos do procedimento de dispensa e de inexigibilidade de licitação."
} 
do art. $59^{203}$, passa a ser aplicável também aos contratos celebrados pelo Poder Público.

No entanto, naqueles casos em que o autocontrole não se mostrar suficiente para fiscalizar as contratações da Administração Pública, entrará o controle externo, a ser exercido pelo Poder Judiciário e pelos Tribunais de Contas $^{204}$, independentemente da modalidade de contrato da Administração Pública que se analise.

\section{Das decisões do Conselho de Estado Francês}

Para melhor compreender a origem das discussões atualmente travadas pela doutrina e enfrentadas no controle externo dos contratos privados da Administração Pública, cabe recorrer a um breve histórico de decisões relevantes relacionadas a contratos da Administração Pública emitidas pelo Conselho de Estado francês, responsável pela construção inicial da concepção que atualmente vigora no Brasil ${ }^{205}$.

Sobre o assunto, Fernanda Kellner de Oliveira Palermo destaca:

"Ponto essencial e marcante na evolução desta figura contratual no direito pátrio é aquele originado na teoria da cláusula exorbitante, do Direito francês, porque permite estabelecer a diferença entre os contratos administrativos e os contratos de direito privado. A comparação do

\footnotetext{
203“Art. 59. A declaração de nulidade do contrato administrativo opera retroativamente impedindo os efeitos jurídicos que ele, ordinariamente, deveria produzir, além de desconstituir os já produzidos.

Parágrafo único. A nulidade não exonera a Administração do dever de indenizar o contratado pelo que este houver executado até a data em que ela for declarada e por outros prejuízos regularmente comprovados, contanto que não lhe seja imputável, promovendo-se a responsabilidade de quem lhe deu causa."

${ }^{204}$ Enquanto o caput do art. 113 da Lei Federal n. ${ }^{\circ}$ 8.666/1993 estabelece que "o controle das despesas decorrentes dos contratos e demais instrumentos regidos por esta Lei será feito pelo Tribunal de Contas competente, na forma da legislação pertinente, ficando os órgãos interessados da Administração responsáveis pela demonstração da legalidade e regularidade da despesa e execução, nos termos da Constituição e sem prejuízo do sistema de controle interno nela previsto", o caput do art. 41 da Lei Federal n. ${ }^{\circ}$ 8.443/1992 (que dispõe sobre a Lei Orgânica do Tribunal de Contas da União) estabelece que "para assegurar a eficácia do controle e para instruir o julgamento das contas, o Tribunal efetuará a fiscalização dos atos de que resulte receita ou despesa, praticados pelos responsáveis sujeitos à sua jurisdição".

${ }^{205}$ Maria Sylvia Zanella Di Pietro bem assevera que "o direito administrativo francês, de formação pretoriana, foi sendo elaborado a partir de decisões do Conselho de Estado (órgão de cúpula da jurisdição administrativa) que, analisando os casos concretos que lhe eram submetidos, foi derrogando, em rewlação a vários institutos do jus civile, as normas do direito privado, por entender que elas eram inadequadas quando aplicáveis à Administração Pública. Daí os conceitos de serviço público, contrato administrativo, decisão executória, responsabilidade civil baseada na culpa do serviço público e no risco, propriedade pública" (DI PIETRO, Maria Sylvia Zanella. Ainda existem os chamados contratos administrativos?, cit., p. 400).
} 
instituto da cláusula exorbitante, na jurisprudência francesa, que formou rigorosa colocação jurídica, a partir do julgamento de centenas de questões, que envolvem contratos administrativos, permite que o jurista brasileiro, diante de hipóteses semelhantes, decididas pelos tribunais brasileiros, empreenda o regime jurídico do contrato administrativo, ressaltando neste, o papel fundamental da cláusula que J. Cretella Júnior (In: Dos contratos administrativos. Rio de Janeiro: Forense, 1997, p. 49) denomina cláusula de privilégio."206

Georges Péquignot ${ }^{207}$ faz um levantamento histórico de grande serventia, por meio do qual esclarece que até o final do século XIX, o Conselho de Estado francês se guiava pela presença do serviço público nos contratos para distinguir os contratos administrativos dos contratos privados da Administração Pública. Até então, na França se reconhecia duas modalidades de contratos, sendo que, por natureza, os contratos da Administração Pública eram considerados contratos privados, porquanto recaíam sobre a alcunha de atos de gestão (e não de império). Utilizava-se, desta forma, o critério do objeto do litígio para distinguir as modalidades, e não do regime jurídico do contrato. Dessa forma, os contratos da Administração Pública seriam administrativos apenas excepcionalmente, sendo necessário dispositivo legal que lhes conferisse tal qualidade ${ }^{208}$.

A teorização sobre a diferenciação entre contratos administrativos e contratos privados da Administração - com o escopo primordial de fixar a competência para apreciar cada caso, eis que contratos privados deveriam ser encaminhados ao Poder Judiciário, enquanto contratos administrativos recairiam sob a competência do contencioso administrativo, representado pelo Conselho de Estado - no âmbito do Conselho de Estado $^{209}$ tem início com o já famoso aresto Blanco ${ }^{210}$, quando o Tribunal de Conflitos

\footnotetext{
${ }^{206}$ PALERMO, Fernanda Kellner de Oliveira. Escorço histórico do contrato administrativo. Jus Navigandi, Teresina, ano 7, n. 54, 1 fev. 2002. Disponível em: <http://jus.uol.com.br/revista/texto/2647>. Acesso em: 05 nov. 2010.

${ }^{207}$ PÉQUIGNOT, Georges. op. cit., p. 5 e ss.

${ }^{208}$ Id. Ibid., p. 6.

${ }^{209}$ Sobre a importância da construção jurisprudencial do Conselho de Estado francês, Oswaldo Aranha Bandeira de Mello destaca: "[O Conselho de Estado] criou a figura do contrato administrativo quando tinha por objeto a execução direta de obra pública ou a prestação de serviço público; ou a obtenção de bens, que constituíssem meios imediatos e contínuos para consecução de suas atividades fins; ou assim fôsse legalmente classificado ou estabelecido no próprio ajuste, ante o regime jurídico adotado, exorbitante do direito comum.

Êsse contrato quanto à execução se faz nos têrmos de determinação da Administração Pública, na conformidade das exigências do interêsse público, de que é árbitra, alteráveis livremente por ela as suas cláusulas, mediante atos normativos ou decisões executórias, contanto que assegure à outra parte, isto é, ao particular, administrado, a equação econômico-financeira, razão do ajuste feito.
} 
francês teve que decidir sobre a competência para julgar ação versando sobre a titularidade da responsabilidade por danos físicos causados a uma menina (Agnès Blanco) que se encontrava no pátio quando do acidente.

Por meio de tal aresto, fixou-se a competência de julgar pela afetação da matéria ao serviço público, abandonando-se a anterior divisão de competência pela distinção entre atos de império e de gestão (atualmente criticada pela doutrina) e passando-se à fixação da competência do Conselho de Estado para quaisquer atos de administração.

Este aresto também marcou o início da modificação do entendimento que até então vigorava na França de que os contratos só poderiam ser considerados administrativos por força de determinação legal ${ }^{211}$.

Com o aresto Blanco introduziu-se o entendimento quanto à existência de contratos administrativos por natureza, como, por exemplo, aqueles referentes a serviços públicos. Por meio deste aresto também se alçou o Conselho de Estado à categoria de jurisdição administrativa de direito comum, o que reforçou a consolidação da teoria dos contratos administrativos por natureza.

Naquela ocasião, o Tribunal de Conflitos decidiu que o caso deveria ser encaminhado ao Conselho de Estado, por ser o Município responsável pelo serviço que

Esta concepção do contrato administrativo, originária do Conselho de Estado da França, foi acolhida pela doutrina e inserta na legislação dêsse país. Estendeu-se pelos países de língua latina. Vemo-la sustentada na Espanha (cf. Recaredo Fernandez de Velasco (Calvo), Los Contratos Administrativos, Madrid Libreria General de Victoriano Suárez, 1927, Sabino Álvares Gendin, Contratos Administrativos, Editorial Reus S.A., Madrid, 1934) e Portugal (cf. João de Melo Machado, , Teoria Jurídica do Contrato Administrativo, Coimbra, Editoria Ltda. s/d) e na América Latina, em seus diferentes países, pelos mais afamados juristas (cf. Miguel Angel Bercaitz, Teoria General de los Contratos Administrativos, Editora De Palma, Buenos Aires, 1952)." (BANDEIRA DE MELLO, Oswaldo Aranha. Contrato de direito público ou administrativo, cit., p. 20-21).

${ }^{210}$ Julgamento este de primeira importância também para os temas do serviço público e responsabilidade civil do Estado, conforme Tribunal de Conflitos, 8 de fevereiro de 1873: D. 1873, 3, 17; S. 1873, 3, 153. Cabe ressaltar que a doutrina também destaca como precursores relevantes de tal caso os arestos "Rothschild", de 1855, e o "Dekeister" de 1861, mas que, todavia, são de reduzida importância para a questão da distinção entre contratos administrativos e contratos privados da Administração Pública. Sobre o assunto, ver LONG, M.; WEIL, P.; BRAIBANT, G. et al. Les Grands Arrêts de la Jurisprudence Administrative. Paris: Dalloz, 1996, $11^{a}$ ed., p. 1-7; JUSTEN, Mônica Spezia. A noção de serviço público no direito europeu. São Paulo, Dialética, 2003. p. 22-26; GROTTI, Dinorá Adelaide Musetti. O serviço público e a Constituição brasileira de 1988. São Paulo: Malheiros, 2003, p. 27-31; e BANDEIRA DE MELLO, Celso Antônio. Natureza e Regime Jurídico das Autarquias. São Paulo: RT, 1968, p. 139, nota 16.

${ }^{211}$ Como, por exemplo, a lei de 28 do Pluvioso do Ano VIII, de 28 de fevereiro de 1800, e e a lei de 11 de junho de 1896, conforme observa MONCADA, Luís S. Cabral. O problema do critério do contrato administrativo e os novos contratos-programa, cit., p. 10-11, anteriormente publicado em Boletim da Faculdade de Direito da Universidade de Coimbra, numero especial, estudos em homenagem a J.J. Teixeira Ribeiro, Coimbra, n. 2, p. 585-637, 1979. 
gerou os danos. Muito embora diretamente ligado ao tema dos serviços públicos, este julgado apresenta a utilização do critério da natureza jurídica da parte para determinar que se trata de matéria de direito público.

No início do século XX, todavia, tal órgão começou a atentar mais para as peculiaridades da atuação administrativa, para diferenciar o serviço público efetivo da ação ordinária do Estado.

Em 1903, ao julgar o aresto Terrier ${ }^{212}$, também conhecido popularmente como aresto das víboras ${ }^{213}$, no qual o Sr. Terrier demandava pagamento de prêmio pelo Departamento de Saône-et-Loire, por haver matado uma serpente e, em função de contrato celebrado com aquele órgão com a finalidade de exterminar animais nocivos da região (pagamento este que o departamento se negava a realizar sob alegação de insuficiência orçamentária), o "relator" 214 do caso (Romieu), delimitou o que havia sido decidido no aresto Blanco, estabelecendo que mesmo quando relativos a um serviço público, somente seriam administrativos aqueles contratos celebrados no exercício da gestão pública; todos os outros contratos, ligados à gestão privada mesmo no campo administrativo (ou seja, que se referissem à atução de órgão da Administração Pública enquanto pessoa jurídica) seriam considerados privados e, portanto, sujeitos ao Poder Judiciário ${ }^{215}$.

As únicas exceções a tal regra seriam aquelas ocasionadas por regras de competência especiais determinadas pelo legislador e disposições expressas da lei, casos estes em que um contrato da Administração Pública poderia ser declarado administrativo ou privado.

O teor da decisão proferida no aresto Terrier foi corroborado, dois anos depois, em 31 de julho de 1910, por meio do aresto Thérond, que basicamente fixou competência do Conselho de Estado relacionada a um contrato celebrado pelo Sr. Thérond e o Município de Montpellier para, com exclusividade, recolher cães sem dono ao canil municipal e

\footnotetext{
${ }^{212}$ Conselho de Estado, 6 de fevereiro de 1903; D. 1904, 3, 65; S. 1903, 3, 25.

213“"Arrêt des vipères".

${ }^{214} \mathrm{O}$ "comissário de governo" (commissaire du government) é o membro do Conselho de Estado que é escolhido para exercer a função de relator do processo (rapporteur public). Como tal, deve exarar um parecer sobre o caso, que servirá de base para os demais membros deliberarem sobre a decisão a ser tomada.

${ }^{215}$ Esse aresto foi também responsável por incluir os contratos celebrados pelas autoridades descentralizadas locais - notadamente as comunas e departamentos - dentre aqueles que se submeteriam ao contencioso administrativo.
} 
adotar medidas de saúde pública com relação a animais dentro dos limites do Município. Neste caso, o Conselho de Estado acrescentou o critério do serviço público àqueles que já haviam sido utilizados anteriormente no aresto Terrier.

Em 31 de julho de 1912, em um novo aresto (Societé des Granits Porphyrö̈des des Vosges), o Conselho de Estado declara sua própria incompetência para versar sobre um pedido do fornecedor privado de que se anulasse a decisão do Prefeito do Município de Lille tomada em 20 de novembro de 1907 de lhe aplicar penalidade (retenção de parte do pagamento) prevista contratualmente por conta de um atraso na entrega de pavimentação ao Município de Lille, oriundo de contrato privado de fornecimento, pois mesmo que ligado a um serviço público, o objeto do contrato era inegavelmente privado e, por esta razão, deveria ser levado ao crivo do Poder Judiciário.

A decisão do Conselho de Estado conteve afirmação no sentido de que “considerando que o negócio celebrado entre o município e a sociedade era exclusivo de todo trabalho a executar pela sociedade e tinha como único objeto o fornecimento de suprimentos segundo as regras e condições dos contratos celebrados entre particulares; portanto, o pedido que levanta uma contestação não compete à jurisdição administrativa conhecer; que, consequentemente, o requerimento da sociedade não é admissível"216.

Diante da verificação da adoção de diferentes critérios de delimitação de competência pelo Conselho de Estado, com, de um lado, o que havia sido decidido nos arestos Terrier e Thérond (uso do critério do serviço público) e, de outro, o que fora decidido no aresto Societé des Granits Porphyroïdes des Vosges (uso do critério da natureza jurídica do contrato), a situação permaneceu obscura para os doutrinadores da época, até 20 de abril de 1956, quando o Conselho de Estado decidiu acerca do aresto Époux Bertin ${ }^{217}$, caso no qual o casal Bertin celebrou em 24 de novembro de 1944 um

\footnotetext{
${ }^{216}$ Tradução livre. No original: "Considérant que le marché passé entre la ville et la société, était exclusif de tous travaux à exécuter par la société et avait pour objet unique des fournitures à livrer selon les règles et conditions des contrats intervenus entre particuliers ; qu'ainsi ladite demande soulève une contestation dont il n'appartient pas à la juridiction administrative de connaître ; que, par suite, la requête de la société n'est pas recevable". ARRET Société des Granits Porphyroïdes des Vosges. Disponível em: $<$ http://www.lexinter.net/JPTXT2/arret_societe_des_granits_porphyroides_des_vosges.htm>. Acesso em: 15 set. 2010.

${ }^{217}$ Conforme LONG, Marceau; WEIL, Prosper; BRAIBANT, Guy; DELVOLVÉ, Pierre; GENEVOIS, Bruno. Les grands arrêts de la jurisprudence administrative. Paris: Dalloz, 1996. p. 529. Íntegra da decisão em ARRET Epoux Bertin. Disponível em: <http://www.lexinter.net/JPTXT2/arret_epoux_bertin.htm>. Acesso em: 15 set. 2010.
} 
contrato verbal com a Administração Pública francesa para albergar soviéticos do centro de repatriamento de Meaux, que seriam posteriormente repatriados após a libertação da França, pelo que deveriam receber 30 francos diários por pessoa.

Por conta da dualidade de critérios adotada pelo Conselho de Estado até então, notou-se que, muito embora o contrato em questão não contivesse cláusulas de direito público (exorbitantes), seu objeto (abrigo para repatriação de estrangeiros durante uma guerra) era inegavelmente público ${ }^{218} \mathrm{e}$, assim, a competência para julgar pertencia ao Conselho de Estado ${ }^{219}$.

Cabe ressaltar que, já anteriormente, em 1924, na decisão emitida no âmbito do aresto Cie. Des Transports Maritimes ${ }^{220}$, se notava a observação de que não bastava apenas a presença do termo "serviço público" para avocar automaticamente, em caso de litígio, a competência administrativa.

Na mesma época, em suas conclusões sobre o aresto Gaz de Poissy ${ }^{221}$, o Conselho de Estado, por meio do "relator" Corneille, declarou:

\footnotetext{
${ }^{218}$ Conforme observa Oswaldo Aranha Bandeira de Mello, a construção jurisprudencial do Conselho de Estado demonstrou que, por não serem as prerrogativas públicas passíveis de derrogação, mesmo na ausência de cláusulas exorbitantes poderão ser invocadas: "Entendeu a jurisprudência dop Conselho de Estado, simplesmente, que essa prerrogativa legal da Administração pública de alterar o regime de execução do contrato consiste em preceito de ordem pública, que não poderia ser derrogado pelos contratos, e, o silêncio a respeito, nas suas cláusulas, jamais induzia renúncia à aplicação do supracitado preceito legal." (BANDEIRA DE MELLO, Oswaldo Aranha. Contrato de direito público ou administrativo, cit., p. 29).

${ }^{219} \mathrm{O}$ Conselho de Estado acabou por rejeitar o pedido do casal Bertin, alegando que eles não lograram êxito em demonstrar a existência do contrato verbal e seus termos: "Au fond : Considérant que les époux Bertin n'apportent pas la preuve de l'existence de l'engagement complémentaire susmentionné ; que, dans ces conditions, ils ne sont pas fondés à demander l'annulation de la décision en date du ler juin 1949 par laquelle le Ministre des Anciens Combattants et Victimes de la Guerre a refusé de leur verser le montant des primes supplémentaires qui auraient été prévues audit engagement; DECIDE: Article 1er - La requête susvisée des époux Bertin est rejetée. Article 2 - Les époux Bertin supporteront les dépens. Article 3 Expédition de la présente décision sera transmise au Ministre des Anciens Combattants."

${ }^{220}$ Cass. Req. 31 de janeiro de 1923: S. 1924, 1, 129.

${ }^{221}$ Conselho de Estado, 08 de fevereiro de 1918, Sté d'éclairage de Poissy: D. 1919, 3, 9; S. 1924, 3, 2 , tradução livre. No original: "Dans tout contrat intéressant le fonctionnement meme des services publics, l'Etat ne contracte pas comme un simple particulier. Il ne cherche pas à gérer des intérêts tout restreints, des intérêts d'individualités, des intérêts individuels. Il contracte pour une collectivité, pour le public, pour les usagers du service public, pour l'intérêt collectif et general. Et alors, toutes les fois qu'il passé véritablement un marché de service public, il fait quelque chose chose d'autre que ce que fait un contractant ordinaire, un contractant du Code civil ou du Code de commerce. Puis-qu'il fait quelque chose d'autre que ce contractant ordinaire, il ne faut pas appliquer à ce quelque chose les mêmes règles qu'aux contrats de droit commun; c'est la logique et, par suíte, c'est le droit. De là est née l'idée, qui est à la base de le droit administratif moderne, qu'il y a, dans le contrat de service public, une situation juridique différente de celles qui fon l'objet du titre des obligations du Code civil, situation qui doit se traduire par des différences de principe (...)."
} 
"Em qualquer contrato relativo ao próprio funcionamento dos serviços públicos, o Estado não contrata como um simples particular. Ele não procura gerir os interesses restritos, os interesses das individualidades, os interesses individuais. Ele contrata por uma coletividade, para o público, para os usuários de serviço público, pelo interesse coletivo em geral. E mais, todas as vezes em que se depara verdadeiramente com um negócio de serviço público, ele faz algo distinto do que faz um contratante ordinário, um contratante do Código civil ou do Código comercial. Ele pode fazer algo diferente que o contratante ordinário, ele não deve aplicar a tal coisa distinta as mesma regras que aos contratos de direito comum; é a lógica e, por conseguinte, é o direito. Disto decorre a idéia que se encontra na base do direito administrativo moderno, que há, no contrato de serviço público, uma situação jurídica distinta daqueles que são objeto do título das obrigações do Código civil, situação que se deve traduzir pelas diferenças de princípios (...)."

O único exemplo de aresto do Conselho de Estado francês citado por Georges Péquignot $^{222}$ primariamente focado em um contrato privado da Administração Pública é o relacionado à locação de um imóvel de propriedade de uma comuna ao Estado ${ }^{223}$.

Diante deste histórico de julgados do Conselho de Estado, convém mencionar a utilíssima organização com fins didáticos preparada por Eduardo García de Enterría e Tomás-Ramón Fernández ${ }^{224}$ que, dividindo as decisões daquele órgão jurisdicional em três fases, destacam que inicialmente a preocupação do Conselho de Estado em diferenciar as duas modalidades de contratos da Administração Pública tinha o escopo de fixar competência (e, portanto, o Tribunal de Conflitos frncês desempenhou papel fundamental com o aresto Blanco).

Uma vez chegando a uma decisão quanto à repartição de competências entre o Poder Judiciário e o Conselho de Estado, passou-se paulatinamente a um processo de substantivização deste instrumento da Administração Pública (contrato), caracterizador da segunda fase. Trata-se de uma evolução natural da discussão inicial, referente à competência para apreciar a matéria, pois as discussões travadas acabaram em seu curso por se deparar com uma diferença de objeto entre os contratos privados e os contratos administrativos.

\footnotetext{
${ }^{222}$ PÉQUIGNOT, Georges. op. cit., p. 7.

${ }^{223}$ Conselho de Estado, 13 de fevereiro de 1942, Commune de Sarlat: Recueil Lebon, p. 49.

${ }^{224}$ GARCÍA DE ENTERRÍA, Eduardo; RAMÓN FERNÁNDEZ, Tomás. op. cit., p. 691.
} 
Assim, no início do século XX, com o aresto Terrier e a consolidação do critério do serviço público como definidor das diferenças entre os contratos privados da Administração Pública e os contratos administrativos, surge o envolvimento de interesse público como caracterizador da natureza jurídica pública.

Por fim, Eduardo García de Enterría e Tomás-Ramón Fernández mencionam a terceira fase, contemporânea, em que haveria um movimento de busca da eficiência pela atuação privada na seara dos serviços públicos. Nela, a substantivização que marcou a segunda fase não mais desempenharia papel de relevo para se decidir pela aplicação do direito público aos contratos da Administração, havendo uma mistura de difícil delineamento entre o direito civil e o direito administrativo. Nesta terceira, fase, os autores falam na existência de um regime único misto, cuja incidência de uma ou outra modalidade de direito variaria conforme o caso. Todavia, os autores não apresentam um embasamento jurisprudencial para caracterizar esta terceira fase.

\section{Dos exemplos específicos encontrados na jurisprudência pátria}

Após a verificação da evolução histórica França, país que serve de paradigma ao direito administrativo brasileiro, passa-se ao exame do panorama nacional.

Uma das análises mais extensas feitas por um Tribunal pátrio e que, inclusive, aborda a diferenciação entre contratos administrativos e contratos privados da Administração Pública foi a realizada pelo Egrégio Supremo Tribunal Federal ("STF”) no Recurso Extraordinário n. ${ }^{\circ}$ 89.217-6/SC:

"EMENTA: - ADMINISTRATIVO. 1) Contratos da Administracão. Distincão entre contratos privados da Administracão e contratos públicos da Administracão. Somente quanto aos últimos é possível reconhecer à administracão, em princípio, o poder de rescisão unilateral, por motivo de inexecução das obrigacõos de concessionário e para satisfacão de interesse coletivo, sujeito o ato a controle 'a posteriori' para eventual satisfacão de perdas e danos. 2) Contrato pra exploração de hotel e de fontes de águas minerais de propriedade e lavra do estado de Santa Catarina, em Caldas da Imperatriz. Nele não há regras atinentes e custos e tarifas, que caracterizam a concessão de serviço público: trata-se de arrendamento 
complexo, em que as partes estão em pé de igualdade, nem há cláusulas inequivocamente exorbitantes da disciplina de relações jurídicas privadas, havendo-se, no contrário, incompatíveis com o poder implícito da rescisão unilateral, acrescendo, ainda, que não deve ser considerado serviço público aquele que outro particular pode prestar independentemente de concessão. 3) Rescisão que não poderia ter sido decretada unilateralmente por decretada unilateralmente por decreto do Poder Executivo. Conhecimento e provimento do recurso extraordinário, para concessão de segurança" (Recurso Extraordinário 89217, destacamos)

Naquela oportunidade, ao analisar a possibilidade de rescisão unilateral de contrato para lavra de águas e exploração de estância com prazo certo, o STF teve que decidir sobre a natureza jurídica do instrumento em questão: embora denominado "contrato de arrendamento" (modalidade que se enquadra dentre os contratos privados da Administração Pública), alguns dos Ministros entenderam tratar-se de contrato de concessão (contrato administrativo).

Por fim, embora divergente, o Tribunal acabou por decidir se tratar de contrato privado da Administração Pública por haver cláusulas típicas de contratos privados, como a que escolhia a via da arbitragem para solucionar quaisquer conflitos advindos do contrato (critério da natureza jurídica das cláusulas contratuais). Além disso, entendeu que o contrato carecia de elementos que configurassem apropriadamente uma concessão de serviço público (muito embora houvesse cláusula contratual dispondo sobre a possibilidade de desapropriação de bens imóveis relacionados ao objeto do contrato).

Assim, restou consignado o entendimento preponderante que a eleição da via arbitral seria uma exclusão tácita da prerrogativa - de todo estranha ao direito civil, porquanto fruto de posição de supremacia da Administração Pública - de rescisão unilateral do contrato pelo Poder Público, mantendo o contrato em questão sob a égide do direito comum.

A ausência de supremacia do Poder Público nos contratos privados foi também ressaltada no Recurso Especial n. ${ }^{\circ}$ 172.724/SP (98/0030876-8), ocasião em que o STF analisou contrato de compra e venda celebrado pelo Município de Limeira/SP. Assim decidiu o Órgão Guardião da Constituição Federal: 
"EMENTA: ADMINISTRATIVO. CONTRATO DE COMPRA E VENDA. APLICACÃO DAS REGRAS DO DIREITO PRIVADO. NÃO SUPREMACIA DO PODER PÚBLICO NA RELACÃO JURÍDICA FIRMADA ENTRE AS PARTES CONTRATANTES. INEXISTÊNCIA DE VÍCIO A INVIABILIZAR O CUMPRIMENTO DO CONTRATO. RECURSO IMPROVIDO.

1. Nos contratos de compromisso de compra e venda celebrados entre a Administração e o particular, aquela não participa com supremacia de poder, devendo a dita relação jurídica reger-se pelas regras do Direito Privado.

\section{(...)}

No caso, não se trata de contrato administrativo típico. A administração não participa da relação jurídica questionada com supremacia de poder. Pelo contrário, o contrato feito entre as partes é regido pelas normas do direito privado. E, como ensina José Cretella Junior: 'Os contratos privados da Administração regem-se pelo Código Civil ou Comercial, os contratos públicos da Administração, ao contrário, pelas características especialíssimas que se revestem, porque estão sujeitos a regime autônomo, típico, que derroga, ultrapassa ou exorbita as normas de direito comum, o que é evidente, porque as pessoas públicas, quando contratam, não se encontram na mesma situação que os simples particulares. Outras as finalidades, outras as condições, outro o regime jurídico' (Curso de Direito Administrativo - págs. 395 e 396 - Forense)." (destacamos)

O Tribunal Regional Federal (“TRF”) da 2 $2^{\mathrm{a}}$ Região também analisou as diferenças entre contratos administrativos e contratos privados da Administração, esclarecendo que, muito embora os princípios de ambas as modalidades sejam os mesmos, as regras aplicáveis divergem, por se tratar de dois regimes jurídicos divergentes:

"EMENTA: ADMINISTRATIVO. CONTRATO PRIVADO DA ADMINISTRAÇÃO SOB A ÉGIDE DO DIREITO PRIVADO. INTELIGÊNCIA DA LEI 9.656/98 E DA LEI $\mathrm{N}^{\circ} \quad 8.078 / 90$. IMPOSSIBILIDADE DE EXCLUSÃO UNILATERAL DE DEPENDENTES INDIRETOS PELA OPERADORA DE PLANO DE SAÚDE PRIVADO. RECURSOS IMPROVIDOS. 1. No caso dos autos é questionada a exclusão dos dependentes indiretos do seguro saúde coletivo da Sul América Saúde Ltda., contratado pelo Ministério da Agricultura, através de processo licitatório. 2. Os contratos privados da Administracão Pública têm regime especial que utiliza regras do Direito Privado. Ou seja, ainda que os princípios dos contratos administrativos e dos contratos de direito privado praticados pela Administracão sejam os mesmos, as regras aplicáveis a esses últimos não são as mesmas aplicáveis nos contratos administrativos. 3. A Lei impõe vedação às operadoras de saúde quanto a suspensão ou rescisão unilateral dos contratos, principalmente em razão da idade avançada dos 
segurados 4. A questão também se subordina as normas do Código de Proteção e Defesa do Consumidor - Lei $n^{\circ}$ 8.078/90, que assegura ao consumidor o direito de informação, conforme dispõe em seu art. $6^{\circ}$. No art. 51 o CDC também dispõe que 'são nulas de pleno direito, entre outras, as cláusulas contratuais relativas ao fornecimento de produtos e serviços que: (...) XI - autorizem o fornecedor a cancelar o contrato unilateralmente, sem que igual direito seja conferido ao consumidor;' 5. Portanto, concluí-se que caberia à operadora de saúde comunicar previamente da exclusão das seguradas. E não há comprovação que esta comunicação via internet tenha chegado às autoras. Destarte, a pretensão autoral merece acolhimento. 6. Recursos improvidos." 225

Pode-se notar, nessa decisão, a utilização pelo Tribunal do critério da natureza jurídica dos princípios e regras que norteiam o contrato.

Outro precedente que fornece abordagem esclarecedora é a Apelação julgada pelo E. Tribunal de Justiça do Estado de São Paulo, na qual restou consignado que não há preponderância da vontade do Estado nos contratos da Administração que sejam regidos pelo direito civil. A conclusão sobre o regime jurídico aplicável ao caso tomou por base a inexistência de cláusulas exorbitantes ou correlação com serviço público (critério da natureza jurídica das cláusulas contratuais):

"Ementa: CONTRATO ADMINISTRATIVO - Competência recursal contrato de autofinanciamento sob regime de Direito Privado, face à inexistência de cláusulas exorbitantes ou correlação com serviço público, de tal sorte que não há preponderância da vontade do Estado - Competência das Câmaras de Direito Privado deste Tribunal - Precedentes. Recurso não conhecido."

Diante dos julgados ora transcritos, percebe-se que aparentemente a existência de jurisdição uma no Brasil parece afastar parte das discussões acerca da diferenciação entre contratos privados da Administração Pública e contratos administrativos. No entanto, podese verificar que o Poder Judiciário pátrio tende a se apegar a uma fórmula mais objetiva de análise sobre o regime jurídico preponderante sobre um determinado contrato celebrado pelo Poder Público, sendo vários os critérios que já foram isoladamente adotados.

\footnotetext{
${ }^{225}$ APELAÇÃO CIVEL - 349851, 6 ${ }^{\text {a }}$ Turma Especializada, Relator Desembargador Federal Guilherme Calmon Nogueira da Gama, DJU de 26/08/2009, página 70, destacamos.

${ }^{226}$ Apelação Cível n. ${ }^{\circ}$ 582.607.5/4-00, Comarca de Ribeirão Preto, Apelante José Ricardo de Carvalho, Apelada Prefeitura Municipal de Ribeirão Preto, destacamos.
} 
Como já pudemos observar não só na doutrina, como também nos julgados mais relevantes do Conselho de Estado francês sobre o assunto, não há uma fórmula única objetiva que permita separar o joio do trigo em matéria de contratos da Administração Pública. Por esta razão, os julgados encontrados acabam por demonstrar um cenário simplista por demasia, que evita adentrar às discussões mais relevantes e peculiares das duas modalidades de contratos da Administração Pública, a demonstrar a necessidade de se promover estudos mais detalhados sobre o assunto.

Mais uma vez, ressaltamos a importância da escolha de conjuntos diversificados de critérios para diferenciação das modalidades de contratos da Administração Pública para que sejam aplicados concomitantemente para assim se encontrar uma "zona de intersecção" que permita uma maior exatidão do resultado. Este método, que ainda não é utilizado pelo Poder Judiciário brasileiro, poderia representar um avanço na análise das regras aplicáveis aos contratos celebrados pelo Poder Público. 


\section{CAPÍTULO V. PROGNÓSTICO E CONSTAÇÕES FINAIS}

\section{Nossa opinião acerca do ambiente atual dos contratos da Administração Pública}

$\mathrm{Na}$ busca obstinada por inovar o direito, muitos autores acabam adotando por política a defesa de opniões extremadas. Caso, no entanto, tais opniões não sejam devidamente fundamentadas, fruto de extensa reflexão, acabam por resultar em conclusões que têm como único resultado surpreender, sem, contudo, efetivamente convencer os demais.

Diante do estudo realizado, nos parece que até o presente momento os contratos celebrados pela Administração Pública continuam a ser aquilo que a doutrina predominante defende e a jurisprudência reconhece há mais de um século: instrumentos formalizadores de negócios jurídicos que por um lado buscam atender às necessidades do Estado e de outro os interesses comerciais dos particulares fornecedores. Esta conjunção de vontades pacifica o ambiente de convívio entre tais partes e acaba por resguardar um bem maior: o interesse público, que deve mover constantemente o Poder Público. Com efeito, continuam a existir as duas modalidades de contratação do Estado analisadas no presente estudo: os contratos privados da Administração Pública e os contratos administrativos.

Constatamos que não há, atualmente, no campo dos contratos celebrados pela Administração Pública, um regime jurídico único - apenas público ou puramente privado , e que não há contrato que tenha ao menos potencialmente a chance de vir a ser perturbado por fundamentos típicos de outro regime. Assim, é inegável que certos negócios jurídicos se mostrarm característicos da vida privada e, por esta razão, são predominantemente regidos pelo direito privado e apenas muito excepcionalmente se verificam características típicas do direito público, enquanto outros são relações que somente têm razão de ser no direito administrativo e são por ele regidas (o que, contudo, não impede que certas partes do negócio, comuns a todos tipo de avença, sejam buscadas no direito civil). Este é um fato reconhecido pela Lei Federal n. ${ }^{\circ} 8.666 / 1993$ e pelos tribunais pátrios. 
Os regimes jurídicos público e privado, portanto, permanecem em constante contato, convívio e interação em todo e qualquer contrato celebrado pela Administração Pública, pois mesmo nos negócios típicos do direito privado, ainda assim a Administração não abandona sua natureza jurídica inerente.

Assim, não parece assentir razão àqueles autores que defendem haver no Brasil atualmente um único regime jurídico de contratos da Administração Pública (o que, todavia, deveria ser ratificado por meio do reconhecimento de duas terminologias distintas na lei regente, ao invés de adotar o termo "contrato administrativo" indistintamente).

Diante disso, em nossa opinião, não assente razão àqueles que, diante da constatação do convívio entre dois regimes jurídicos em um mesmo veículo formalizador de vontades, acabam por defender que não há que se falar mais em contratos administrativos e que não há razão de ser para prevalescerem prerrogativas públicas em determinadas situações ${ }^{227}$.

Em outras palavras, a constatação de uma tendência de aproximação entre as duas modalidades de contratos da Administração Pública não resulta necessariamente em um regime jurídico único para todos os eles.

No caso daqueles que defendem o fim das cláusulas exorbitantes, entendemos que tal posição se deve ao fato de tomarem a exceção como se regra fosse, confundirem o abuso ilegal com conduta legítima de Estado, e, assim, terminam por acreditar que estão constatando mudanças radicais e, mais ainda, que estariam presenciando o fim de seu objeto de estudo. As cláusulas exorbitantes são fundamentais à prossecução do interesse público e entendemos não haver possibilidade de as extirpar do mundo jurídico.

Já no tocante àqueles que acreditam que já há no Brasil um único regime jurídico de contratos da Administração Pública, cabe observar que o teor da legislação em vigor e a jurisprudêncua prevalescente demonstram ainda haver uma separação entre estas duas modalidades.

\footnotetext{
${ }^{227}$ Fenômeno semelhante se dá com o instituto do serviço público, vitimado frequentemente por aqueles que enxergam nas suas mudanças decorrentes dos fenômenos sociais o seu fim, confundindo modificações e "lapidações" do conceito com o total obsolescência e desuso do instituto. São incontabilizáveis os anúncios que já foram feitos do fim do serviço público e, no entanto, ele ainda continua a ser figura frequente de uso e estudo, continuando a se apresentar como fundamental ao exercício da cidadania e a inserção efetiva na sociedade.
} 
Com relação àqueles que anunciam o fim dos contratos administrativos na sociedade contemporânea, cabe manter em mente que as ciências humanas não são estanques, que os fenômenos sociais sofrem adaptações, mas que determinados conceitos e instrumentos criados ao longo dos séculos não deixam de existir apenas por conta de evoluções e mudanças culturais. As mudanças são factíveis e, muitas vezes, significativas, mas muito raramente têm o condão de extinguir os conceitos fundamentais. Saber delimitálas nos estudos e verificar se ainda cabem nos conceitos é tarefa dos observadores, que lhes permite emitir opiniões mais abalisadas e ponderadas.

Sobre o assunto, é oportuna a lição de Lucas Rocha Furtado:

"Após vários erros, e alguns acertos, hoje se constata a impossibilidade de total afastamento das normas e dos princípios que constituem o instrumental do Direito Administrativo. Se há novas áreas de atuação do Estado que reclamam maior agilidade, outras continuam a ser pautadas pelos instrumentos tradicionais do Direito Administrativo. De qualquer forma, hoje se verifica, de modo cristalino, que a desqualificação do Direito Público não interessa nem ao Estado nem à sociedade. Portanto, em vez de se afastar o Direito Público, deve-se buscar atualizar seus preceitos e torná-lo capaz de responder de forma pronta e eficaz às demandas que as sociedades modernas apresentam ao Estado. Este constitui o grande desafio que se apresenta aos que lidam com o Direito Administrativo: mantê-lo atualizado, capaz de atender às demandas sociais, sem se afastar dos princípios basilares do Estado Democrático de Direito." ${ }^{, 28}$

Ultrapassada a discussão sobre as proposições 'modernas' de extinção dos contratos administrativos, ainda resta, no entanto, inegável divergência entre opiniões, que divide a doutrina nacional e estrangeira no tocante (i) à existência de "contratos" propriamente ditos tendo a Administração Pública como parte; e (ii) à existência de contratos privados da Administração Pública, que se diferenciam dos contratos administrativos; nossa proposta de solução das divergências entre tais correntes, para atingir um consenso acerca dos contratos celebrados pela Administração Pública é que se promova modificação legislativa que, ao trazer para o âmbito da lei, senão todas, ao menos a maior parte das prerrogativas características de Direito Público a que a Administração Pública faz jus, manterá no âmbito do instrumento contratual propriamente dito apenas aqueles dispositivos característicos de direito privado e que figurariam em um contrato típico.

${ }^{228}$ FURTADO, Lucas Rocha. op. cit., p. 57. 
Resumidamente, entendemos há ainda hoje duas modalidades de contratos passíveis de celebração pela Administração Pública. Enquanto em uma delas há maior incidência de regras do direito privado, na outra há predominantemente regras de direito público. Somente a aplicação concomitante de diferentes critérios de identificação permitirá que se trace uma zona de intersecção que identifique uma destas modalidades (e, por exclusào, os contratos pertencentes à outra modalidade, por exclusão, ficariam nas respectivas zonas exógenas à intersecção). Entretanto, mesmo na modalidade "contratos privados da Administração Pública" haverá sempre potencialmente interesse público envolvido, seja diretamente (contratos administrativos) ou indiretamente (contratos privados da Administração).

Por essa razão, nos parece que o mais correto seria alterar a legislação para pacificar grande parte das correntes doutrinárias divergentes na matéria e tornar mais clara para os particulares que contratam com a Administraçào Pública a potencialidade de prevalescer interesse público, expondo de antemão em que tipo de situações o negócio jurídico em questão poderia vir a ser afetado.

\section{Proposta de tratamento legal dos contratos da Administração Pública}

Diante (i) das dificuldades enfrentadas pela doutrina no escalonamento das regras de direito privado e de direito público nos contratos celebrados pela Administração Pública, (ii) da ausência de clareza, em muitos casos de contratos privados da Administração, quanto à possibilidade de o Poder Público fazer uso de prerrogativas peculiares (bem como da divergência quanto à real juridiciidade disto ocorrer), e (iii) da insistência de alguns autores de tentarem classificar os contratos administrativos como figuras desconexas do conceito de contrato por conta da presença de cláusulas exorbitantes, nossa proposta é retirar do teor dos contratos da Administração Pública as chamadas “cláusulas exorbitantes”, para que, utilizando o princípio da legalidade estrita, venham a ser incluídas de maneira mais detalhada do que a atual na lei de regência dos contratos do Poder Público. 
Essa proposta compreenderia a "avocação" pelo legislador de todas as disposições acerca do exercício de prerrogativas públicas, passando-as do corpo do contrato para o âmbito da lei e, assim, fazendo com que as cláusulas de prerrogativas, também conhecidas como cláusulas administrativas, de privilégio, exorbitantes ou derrogatórias deixassem de ser cláusulas contratuais, passando a ser dispositivos normativos que se aplicariam aos contratos celebrados pela Administração Pública sempre que se verificasse condições motivadoras da aplicação do regime jurídico público justificador de prerrogativas, independentemente do regime jurídico prevalescente no contrato. Para evitar eventuais abusos, tal modificação deveria ser acompanhada pela inserção metodologia de verificação e comprovação da presença de interesse público que, uma vez percorrida pelo intérprete, dê azo à aplicação de prerrogativas públicas ao contrato (novamente mediante regras estabelecidas em lei).

O "acionamento" dessas prerrogativas, portanto, deveria ser sempre acompanhado da necessária motivação demonstradora da ocorrência do evento previsto genericamente pelo legislador e traria consigo a necessidade de observância da equação econômica inicialmente firmada, de modo a se preservar o equilíbrio econômico-financeiro da relação.

Em nossa opinião, não haveria obstáculos para que tal modificação fosse implementada, eis que, conforme corretamente observa Marcos Juruena Villela Souto ao analisar os anteprojetos de lei de autoria de Benedito Porto Neto e de Carlos Pinto Coelho Motta - ambos voltados a substituir a Lei Federal n. ${ }^{o}$ 8.666/1993 -, ressalta que as cláusulas exorbitantes "não têm sede constitucional; assim o legislador infraconstitucional pode prevê-las ou não, bem como condicionar o seu uso",229.

O que motiva a proposta ora descrita - e que, como convém, será melhor descrita nos próximos parágrafos - é o fato de que a aplicação das prerrogativas do Poder Público aos contratos celebrados pela Administração Pública sofre constante questionamento. Algumas vezes tal questionamento se ampara sobre a discussão da aplicabilidade do regime jurídico público a determinado contrato; outras vezes o questionamento se deve à efetiva presença de elemento justificador do acionamento da prerrogativa pública.

\footnotetext{
${ }^{229}$ SOUTO, Marcos Juruena Villela. Direito administrativo contratual. Rio de Janeiro: Lumen Juris, 2004. p. 472.
} 
Nossa opinião, já exposta acima, é a de que atualmente não se deve falar em um regime jurídico único aplicável todo a qualquer contrato celebrado pela Administração Pública. Mesmo naqueles contratos em que todas as cláusulas contratuais sejam regidas pelo direito privado, prerrogativas características de direito público podem vir a ser aplicadas em situações específicas, caracterizadoras de situações justificadoras (pressupostos do dever) de princípios como ao da supremacia do interesse público ${ }^{230}$. Tal constatação é muito bem sumarizada por Maria Sylvia Zanella Di Pietro, ao afirmar que " $a$ conclusão é uma só: pode-se impugnar a presença de cláusulas exorbitantes nos contratos celebrados entre Estado e particular. Mas não se pode acabar com o exercício de prerrogativas públicas durante a execução do contrato" ${ }^{231}$.

No entanto, a supremacia do interesse pública poder potencialmente se manifestar em ambas as modalidades não quer dizer que contratos privados da Administração Pública e contratos administrativos mantenham relação idêntica com o interesse público. Enquanto estes têm uma relação íntima e direta com interesses públicos, aqueles somente se relacionam transversa e indiretamente com intereses públicos. Enquanto nestes a atuação no exercício de prerrogativas é constante, naqueles constitui exceção, que deve necessariamente restar comprovada para ser considerada legítima.

No entanto, nossa proposta fará com que tanto os contratos privados da Administração Pública quanto os contratos administrativos passem a ser redigidos da mesma maneira: sem cláusulas exorbitantes em seu corpo. Estas, previstas na lei e passíveis em aplicação em todo e qualquer contrato da Administração Pública em que se comprove haver interesse público a demandar o exercício de prerrogativa, sofrerão menos questionamentos quanto à sua compatibilidade com o regime jurídico do contrato, devendo-se as eventuais impugnações dirigirem-se à presença de interesse público, à proporcionalidade da prerrogativa e à preservação dos interesses privados na medida do possível, bem como as contrapartidas ao particular.

\footnotetext{
${ }^{230}$ Marçal Justen Filho discorda parcialmente desta opinião, defendendo que "a alteração unilateral dos contratos é incompativel com o funcionamento dessas atividades [privadas]. Não será admitida a imposição compulsória de alterações contratuais - o particular poderá a tanto se opor, preferindo a rescisão do contrato. Assim, por exemplo, uma seguradora particular não pode ser constrangida a manter um contrato de seguro se a Administração deliberar ampliar o objeto segurado ou os riscos incidentes. I Mas as demais competências anômalas - tal como a fiscalização reforçada, o regime especial de recebimento de bens e a própria extinção por decisão unilateral da Administração Pública - podem ser exercitadas, uma vez que não geram risco de comprometimento da iniciativa privada." (JUSTEN FILHO, Marçal. Curso de direito administrativo, cit., p. 487).

${ }^{231}$ DI PIETRO, Maria Sylvia Zanella. Ainda existem os chamados contratos administrativos?, cit., p. 407.
} 
Por meio da modificação cogitada, seria, portanto, implantado um único regime de contratos da Administração Pública.

O princípio da legalidade estrita, aplicável à conduta administrativa, faz com que a "legalização" das prerrogativas contratuais torne a atuação do Poder Público uma obrigação de, naqueles casos previstos em lei - ainda que de maneira geral e abstrata, mas mediante critérios predeterminados, como convém à legislação - fazer valer sua(s) prerrogativa(s). Em outras palavras, a modificação proposta explicita que fazer valer o interesse público dentro dos limites da legitimidade não é uma faculdade do Poder Público, mas sim um dever.

A proposta em questão procura também estabelcer um conceito legal de "método legítimo de exercício de prerrogativas públicas" para evitar abusos e preservar o direito do administrado às contrapartidas. Isto é especialmente relevante, pois atualmente já pode ocorrer o exercício de tais prerrogativas nos contratos da Administração Pública, mas não há uma disciplina de qual seria o procedimento aplicável e nem tampouco isto está evidenciado na legislação a ponto de esclarecer aos entes privados interessados em contratar com a Administração Pública todos os riscos envolvidos e as correspondentes contrapartidas.

Quanto à já existência da possibilidade do exercício das prerrogativas públicas mesmo nos contratos da Administração em que há maior incidêmcia do direito privado, convém lembrar que a Administração Pública detem poder de polícia ${ }^{232} \mathrm{e}$, lhe sendo possibilitado ordenar a atuação daqueles que com ela se relacionam, as prerrogativas de fiscalização e de sancionamento sempre poderiam ser levadas a cabo, senão por ser parte do contrato, ao menos por jamais deixar de ser Administração Pública.

Se o Poder Público é parte de contrato regido majoritariamente pelo direito privado e, a princípio, não poderia se utilizar dessas prerrogativas enquanto pessoa jurídica figurativa da relação jurídica (negócio jurídico), ainda assim a Administração Pública pode

\footnotetext{
${ }^{232}$ Carlos Ari Sundfeld sugere a adoção da terminologia "administração ordenadora", que define como " $a$ parcela da função administrativa, desenvolvida com o uso do poder de autoridade, para disciplinar, nos termos e para os fins da lei, os comportamentos dos particulares no campo de atividades que lhes é próprio" (SUNDFELD, Carlos Ari. Direito administrativo ordenador. 1. ed. São Paulo: Malheiros Ed., 1997. p. 20), ao invés de "poder de polícia", pois este termo remeteria a um poder do qual a Administração Pública detinha antes do Estado de Direito e que depois foi transferido para o legislador; porque está ligado ao modelo do Estado liberal clássico; e porque faz supor a existência de um poder discricionário implícito incomum. (Direito administrativo ordenador, cit., p. 17).
} 
fazer uso de seu poder ordernador ${ }^{233}$ para a todo tempo ficalizar uma ou mais partes dos $\operatorname{contratos}^{234}$. Assim, uma vez verificado pela Administração Pública enquanto parte de determinado contrato a presença de um pressuposto legitimador de prerrogativa pública devidamente previsto no ordenamento jurídico, o Poder Público teria, frente ao princípio da legalidade estrita, o dever (ou poder-dever) de fazer valer tal prerrogativa.

No entanto, sob o novo regime proposto, para que tal ação seja considerada legítima, haverá que se atentar para a presença dos demais requisitos (além da previsão legal e da efetiva constatação da presença de pressuposto autorizador no caso, o que deverá ser devidamente demonstrado pela Administração Pública no procedimento administrativo ensejador da prerrogativa pública) autorizadores do exercício da prerrogativa pública: a competência e a legitimidade da prerrogativa.

A competência se refere, na verdade, ao fato de o ente que conclama o exercício de prerrogativa pública no âmbito de contrato dever ser parte do instrumento em questão e integrar a Administração Pública (ou legitimamente representá-la no exercício de atividade públicadelegável e, de fato, delegada a ele, como, por exemplo, no caso de um concessionário de serviço público).

Por sua vez, a legitimidade da prerrogativa diz respeito à necessidade de ser prevista em lei e não extrapolar o âmbito de sua aplicação prevista, preservando ao máximo possível os direitos do ente privado envolvido.

Estas constatações, mais do que desdobramentos diretos dos princípios da razoabilidade e proporcionalidade, se mostram necessárias porque a prerrogativa pública somente pode ser exercida quando essencial e na medida estritamente necessária. Demanda árduo exercício de dosagem, eis que se exercida a menor, o interesse e patrimônio públicos serão lesados. Se exercida em excesso, além de anulável (na medida em que excede a ação legítima), será medida de autoridade incompatível com o Estado Democrático de Direito (prevalecente no Brasil, conforme caput do art. $1^{\mathrm{o}}$ da Constituição Federal). Da mesma maneira, se exercida intempestivamente, será nula; se não exercida, responderá o Estado

\footnotetext{
${ }^{233}$ Como prefere denominar Carlos Ari Sundfeld (Direito administrativo ordenador, cit., p. 15).

${ }^{234}$ Dessa constatação surge um comentário interessante: sem que se defenda uma "esquisofrenia da pessoa jurídica", ainda assim é possível notar que o Poder Público não é uno, de maneira que pode sim, ao mesmo tempo, ter órgão da Administração Pública direta ou indireta figurando como parte de contrato privado da Administração Pública e também figurar como fiscalizador do negócio jurídico.
} 
por omissão lesiva ao interesse e patrimônio públicos.

O controle de eventuais abusos e/ou omissões (advindos da inobservância da proporcionalidade, eficiência e razoabilidade) deveria ser promovido não somente pela própria Administração Pública (fazendo uso da autotutela), como também pelo Tribunal de Contas, Poder Judiciário e Ministério Público. Tais situações são extrajurídicas e, portanto, não devem servir de ensejo a uma busca de um regime totalmente privado. ${ }^{235}$

Mesmo com a verificação da presença de todos os pressupostos legitimadores do exercício da prerrogativa pública, este poder-dever do Estado somente se fará perfeito mediante a correlata e perfeita compensação do particular. Conforme o caso, poderá ser necessário rever a equação econômico-financeira da relação para manter seu equilíbrio justo, efetuar indenização e/ou outro tipo de reparação, sempre na mesma medida da mudança promovida pelo Poder Público.

Não se pode olvidar, ainda, da prerrogativa de sancionamento pela Administração Pública, que em nossa proposta deveria ser deslocada do âmbito do contrato para a lei, tal qual as demais prerrogativas que sejam estranhas ao direito privado (o que não se confunde, todavia, com a inserção de cláusulas penais e correlatas, comuns no direito privado, que poderiam se mantidas no contrato).

Assim, parte do que atualmente é considerado matéria de cláusulas contratuais embasada em previsão genérica legal de prerrogativa pública (e que tem gerado discussões há décadas), por meio desta proposta passaria a ser norma geral de contratação da Administração Pública.

Tal mudança evitaria a falsa impressão de que toda matéria que é objeto de cláusula contratual provém necessariamente de uma negociação propriamente dita ${ }^{236}$, argumento

\footnotetext{
${ }^{235}$ Diogo de Figueiredo Moreira Neto, por exemplo, afirma que as prerrogativas do Estado aumentam a imprecisão e a insegurança das contratações, aumentam os custos de transação por um aumento do risco envolvido e diminuem a transparência e a confiança do administrado nos negócios jurídicos. Todavia, não nos parece ser uma possibilidade abandonar as prerrogativas, eis que envolvem o interesse público, indisponível e não passível de transação. Nesse contexto, nos parece ser mais plausível admitir tal fato, evidenciando os rsicos para os administrados, oferecendo a devida compensação e combater veementemente os abusos (MOREIRA NETO, Diogo de Figueiredo. O futuro das cláusulas exorbitantes nos contratos administrativos. In: ARAGÃO, Alexandre Santos de, MARQUES NETO, Floriano de Azevedo (Coords.), cit., p. 582).

${ }^{236} \mathrm{O}$ que, ademais, não é correto presumir nem mesmo nos contratos celebrados entre entes privados. Com efeito, nos contratos de adesão, que se tornaram tão populares mais recentemente (principalmente com o
} 
muito utilizado por parte da doutrina que entende que não se pode falar propriamente em “contratos” quando uma das partes do instrumento é a Administração Pública.

Caso venha a ser implementada, nossa proposta acarretaria em um regime jurídico único para todos os contratos celebrados pela Administração Pública, aproximando, de certa forma, o que hoje são consideradas por parte da doutrina e por nós mesmo como duas modalidades distintas de contratos da Administração Pública. Via de regra, eles seriam privados na medida do possível, somente se aplicando regras características de direito público nas situações estritamente necessárias, previstas em lei.

Com isso, se eliminaria grande parte da divergência doutrinária e da dificuldade enfrentada por aqueles que exercem o controle porterior da atuação administrativa, pois ao invés de verificar a compatibilidade de uma determinada prerrogativa com o regime jurídico prevalescente sobre o contrato, teria que verificar se as regras de aplicação da prerrogativa foram corretamente utilizadas e se o resultado é legítimo.

Da mesma forma, a presença de cláusulas estranhas ao regime jurídico privado (de prerrogativas, privilégio, administrativas, exorbitantes ou derrogatórias) não mais poderiam ser utilizadas como critério diferenciador entre contratos administrativos e contratos privados da Administração (e os próprios critérios de diferenciação perderiam sua função).

Com efeito, essa proposta, conseguindo lograr êxito na preservaçào do interesse público por meio da atuação administrativa seria benéfica, pois como leciona Maria Sylvia Zanella Di Pietro, é

\footnotetext{
“(...) pouco provável que uma autoridade possa abrir mão, previamente, mediante negociação com o particular, dos poderes de alterar ou de rescindir o contrato unilateralmente, ou dos poderes de fiscalizar e punir. São poderes que, mesmo em caso de omissão no contrato, não podem deixar de ser exercidos se o interesse público o exigir. São poderes irrenunciáveis pela Administração Pública como parte no contrato"237.
}

\footnotetext{
avanço dos negócios jurídicos celebrados no ambiente eletrônico), todas as cláusulas são previamente escolhidas por uma das partes e à outra parte em potencial cabe apenas concordar com todas elas ou optar por não aderir ao contrato, não se tornando efetivamente parte do contrato. Também as condições gerais de contratação, utilizadas em contratos celebrados repetidamente em grande quantidades, estabelecem a priori o que o empresário estipula unilateralmente como condições para que os negócios se concretizem e que deverão necessariamente estar presentes nos contratos caso alguém se interesse em com ele contratar. Uma visão muito útil sobre tais figuras da contratação é fornecida por VENOSA, Sílvio de Salvo. Direito civil: teoria geral das obrigações e teoria geral dos contratos. São Paulo: Atlas, 2002. t. 2, p. 375-389.

${ }^{237}$ DI PIETRO, Maria Sylvia Zanella. Ainda existem os chamados contratos administrativos?, cit., p. 410.
} 
Nesse contexto, caso nossa proposta seja implementada, o exame jurídico a ser promovido pelo intérprete ocupará posição de primeira relevância, na medida em que terá que verificar se os pressupostos ensejadores da prerrogativa estão presentes em determinado caso ou não. Tal análise, obviamente, não se limitará ao instrumento contratual em questão, mas também se estenderá ao contexto no qual se insere, abrangendo a natureza jurídica das partes, os fatos envolvidos, as situações enfrentadas pelas partes etc. Essa análise certamente diminuirá a incidência de interpretações errôneas, assim como a aplicação de cláusulas nulas e reconhecimento de tentativas infundadas de fazer valer prerrogativas.

No tocante à modificação proposta, é conveniente lembrar de lição ministrada por Orlando Gomes ${ }^{238}$, no sentido de que o conjunto de proposições por meio das quais é formulada uma declaração concorde de vontades que se convencionou chamar de contrato, seja ele regido predominantemente pelo direito público ou privado, é composto pelo preâmbulo (onde se qualificam as partes, declara-se a finalidade do negócio e coloca-se as as disposições preliminares) e pelo contexto (onde se ordena as proposições ou regras dos contratos, que se convencionou chamar de cláusulas).

As cláusulas, por sua vez, podem ser classificadas como essenciais (fundamentais para a existência e validade do contrato), naturais (condições subentendidas) ou acidentais (as quais são utilizadas somente em casos de proposição especial). Além disso, algumas vezes cláusulas implícitas também integram os contratos, podendo haver menção expressa a elas no corpo do contrato ou não. A sugestão que ora se debate seria justamente a criação de disposições legais que dispensariam a menção expressa no corpo do contrato às prerrogativas públicas. Em outras palavras, tais cláusulas deixariam de ser cláusulas naturais inseridas no contexto do contrato para passarem a ser cláusulas implícitas, existentes por força de lei mas não expressas no contrato.

Tal modificação, a nosso ver, é, na verdade, um reconhecimento de que as prerrogativas públicas já são, de acordo com a redação da lei em vigor, passíveis de aplicação. O que ocorre, no entanto, é que por conta da redação da Lei Federal n. ${ }^{\circ}$ 8.666/1993, nos contratos administrativos, tais prerrogativas, representadas pelas cláusulas ditas exorbitantes, são consideradas naturais, enquanto nos contratos privados da

\footnotetext{
${ }^{238}$ GOMES, Orlando. op. cit., 18. ed., p. 17.
} 
Administração Pública, não havendo dispositivo expresso sobre o assunto na lei, entendese que o exercício excepcional de prerrogativas públicas se deve ao ordenamento jurídico como um todo e, em última instância, à Constituição Federal, que estabelecem a necessidade de observância ao princípio da supremacia do interesse público e, assim, colocam tais prerrogativas como cláusulas implícitas.

Alguns dirão, acertadamente, que a Lei Federal n. ${ }^{\circ}$ 8.666/1993 já contém dispositivos que estabelecem a possibilidade de utilização de prerrogativas públicas, tais como o art. 58 (aplicável mesmo aos contratos privados da Administração no que couber, por força do $\S 3^{\circ}$ do art. 62), por exemplo, que aborda expressamente a possibilidade de modificação unilateral do contrato para melhor adequá-lo às finalidades de interesse público (inciso I), de rescisão unilateral do contrato (inciso II), de fiscalização da execução do objeto do contrato (inciso III), a prerrogativa de aplicação de sanções por inexecução total ou parcial do contrato, desde que devidamente motivada (inciso IV) e de ocupação provisória de bens móveis, imóveis, pessoal e serviços vinculados ao objeto do contrato (inciso V).

Todavia, a existência de previsão legal de prerrogativas contratuais do Poder Público não dispensa as tarefas de (i) identificar a quais contratos celebrados pela Administração Pública se deve aplicar tais prerrogativas e (ii) inserir nos contratos submetidos ao regime jurídico público cláusulas representativas de tais prerrogativas. Estas são tarefas necessárias ao redator de qualquer contrato celebrado pela Administração Pública atualmente. Nossa proposta, no entanto, é modificar a redação da lei disciplinadora dos contratos celebrados pela Administração Pública, para que passe a prever as hipóteses em que as prerrogativas públicas se aplicam.

\section{Conclusões}

Como já esclarecemos acima, é nosso entendimento que mesmo naqueles casos em que o contrato celebrado pela Administração Pública seja predominantemente regido pelo direito privado, é certo que certas situações específicas, quando devidamente comprovadas, 
podem justificar o exercício de prerrogativas de direito público ${ }^{239}$. E isto se deve ao fato de que a Administração Pública é sempre um ente público, mesmo quando se envolve em negócio jurídico regido pelo direito privado. Prova disto é que mesmo os contratos da Administração Pública regidos pelo regime jurídico privado devem ser precedidos de licitação.

Com o reconhecimento expresso pelo legislador do fato descrito acima, procurar-seia, por exemplo, combater o dispêndio de recursos públicos desenecessariamente apenas para cumprir um pacto de cunho predominantemente privado, o que, a nosso ver, é contrário à função social do contrato ${ }^{240}$, cuja preservação é assegurada pelo art. $421^{241} \mathrm{e}$ pelo parágrafo único do art. $2.035^{242}$ do Código Civil (Lei Federal n. ${ }^{\circ}$ 10.406/2002). Isto se daria por meio do exercício legítimo das prerrogativas públicas em contratos em que atualmente erroneamente acaba por prevalescer o interesse privado em prejuízo do público. Portanto, a alteração legislativa proposta seria conciliável com o Código Civil, mesmo com a prevalência de prerrogativas públicas em todos os contratos da Administração Pública em que se comprove sua legitimidade.

A rescisão unilateral e a alteração unilateral dos contratos pela Administração Pública, por exemplo, seriam utilizadas para promover o gasto consciente e motivado de

\footnotetext{
${ }^{239}$ Como ressalta Lucas Rocha Furtado, "outra observação importante consiste em que, mesmo nas hipóteses em que o Direito Privado possa ser utilizado pela Administração Pública, sempre haverá normas de Direito Público irrenunciáveis e que possuem precedência em relação às do Direito Privado. (...) Vê-se que em relação a esses contratos denominados de Direito Privado, bem como a qualquer outro ato praticado pela Administração Pública, além da inafastável observância do interesse público, sempre haverá normas de Direito Público aplicáveis. Assim sendo, não obstante a crescente importância que o Direito Privado assume como fonte para o Estado, o Direito Público mantém a precedência" (FURTADO, Lucas Rocha. op. cit., p. 55-56).

${ }^{240}$ Miguel Reale leciona que "o que o imperativo da 'função social do contrato' estatui é que este não pode ser transformado em um instrumento para atividades abusivas, causando dano à parte contrária ou a terceiros, uma vez que, nos termos do Art. 187, 'também comete ato ilícito o titular de um direito que, ao exercê-lo, excede manifestamente os limites impostos pelo seu fim econômico ou social, pela boa-fé ou pelos bons costumes'.

Não há razão alguma para se sustentar que o contrato deva atender tão somente aos interesses das partes que o estipulam, porque ele, por sua própria finalidade, exerce uma função social inerente ao poder negocial que é uma das fontes do direito, ao lado da legal, da jurisprudencial e da consuetudinária." (REALE, Miguel. Função social do contrato. Disponível em: <http://www.miguelreale.com.br/artigos/funsoccont.htm>. Acesso em: 24 ago. 2010).

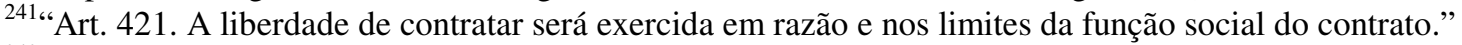

242،“Art. 2.035. A validade dos negócios e demais atos jurídicos, constituídos antes da entrada em vigor deste Código, obedece ao disposto nas leis anteriores, referidas no art. 2.045, mas os seus efeitos, produzidos após a vigência deste Código, aos preceitos dele se subordinam, salvo se houver sido prevista pelas partes determinada forma de execução.

Parágrafo único. Nenhuma convencão prevalecerá se contrariar preceitos de ordem pública, tais como os estabelecidos por este Código para assegurar a funcão social da propriedade e dos contratos." (destacamos)
} 
rescursos públicos, preceito a ser obedecido pelo Estado quando celebra qualquer contrato. Tal preceito demonstra que a liberdade de contratar e de manter contrato não é plena, sendo expressamente delimitada pela necessidade de observância à função social do contrato (art. 421 do Código Civil) e pelo mandato que recebe da sociedade, que vincula a atuação administrativa ao bem-estar coletivo e à preservação dos bens públicos (incluídos aí os recursos financeiros).

Outrossim, o parágrafo único do art. 2.035 do Código Civil evidencia que nenhum contrato pode contrariar preceito de ordem pública, como, por exemplo, a função social do contrato. Ocasionar dispêndio injustificado de verbas públicas vai contra o interesse da coletividade e, como ressalta Miguel Reale, "é natural que se atribua ao contrato uma função social, a fim de que ele seja concluído em benefício dos contratantes sem conflito com o interesse público" (destacamos) ${ }^{243}$.

Da mesma maneira, como esclarece a Constituição Federal, deve a propriedade privada cumprir com sua função social. É de se refletir, portanto, se um imóvel urbano locado à Administração Pública e que por ela - muito embora locatária - não vem sendo utilizado, causando desperdício de recursos públicos, cumpre efetivamente com sua função social. Sendo a conclusão negativa, caberia a rescisão unilateral do contrato pela Administraçào Pública, o que seria facilitado com a previsão de tal possibilidade na lei federal de contratos da Administração Pública, como a que ora propomos.

Nesse contexto, recorrendo mais uma vez ao fato de que a Administração Pública, de maneira geral, fora do âmbito de contratação, sempre dipõe de prerrogativas públicas que lhe permitem agir unilateralmente, lembramos da possibilidade de o Poder Público desapropriar imóveis, prevista expressamente pela Constituição Federal em seus arts. $5^{\circ}$, XXIV; 22, II; $182, \S 3^{\circ}$ e $\S 4^{\circ}$, III; $184 ;$ e $216, \S^{\circ}$.

\footnotetext{
${ }^{243}$ REALE, Miguel. op. cit. Concluindo o seu raciocínio, o Autor afirma que "Na elaboração do ordenamento jurídico das relações privadas, o legislador se encontra perante três opções possíveis: ou dá maior relevância aos interesses individuais, como ocorria no Código Civil de 1916, ou dá preferência aos valores coletivos, promovendo a "socialização dos contratos"; ou, então, assume uma posição intermédia, combinando o individual com o social de maneira complementar, segundo regras ou cláusulas abertas propícias a soluções eqüitativas e concretas. Não há dúvida que foi essa terceira opção a preferida pelo legislador do Código Civil de 2.002.

É a essa luz que deve ser interpretado o dispositivo que consagra a função social do contrato, a qual não colide, pois, com os livres acordos exigidos pela sociedade contemporânea, mas antes lhes assegura efetiva validade e eficácia."
} 
Ora, se atualmente a Administração Pública poderia, em tese, desapropriar um imóvel do qual é locatária em prol do interesse público devidamente comprovado, afetando assim, mediante o procedimento adequado, diretamente um contrato privado, certo é que deve também lhe ser facultado exercer prerrogativa menos onerosa no âmbito deste mesmo contrato. Como já diz o adágio popular baseado na lógica, "quem pode o mais, pode o menos".

Constata-se, assim, que a hipótese do art. $79, \mathrm{I}^{244}$ combinado com o art. 78, XII ${ }^{245}$ da Lei Federal n. ${ }^{\circ}$ 8.666/1993, pode ser invocada mesmo naqueles contratos da Administração Pública regidos predominantemente pelo direito privado. E isto é, inclusive, admitido pelo legislador, ao determinar que as normas gerais contidas na lei se aplicam, no que couber, "aos contratos de seguro, de financiamento, de locação em que o Poder Público seja locatário, e aos demais cujo conteúdo seja regido, predominantemente, por norma de direito privado" (art. 62, $\left.\S 3^{\circ}, \mathrm{I}\right)$. Sendo assim, nada mais justo do que prever de maneira mais clara na lei a possibilidade de o Poder Público instabilizar o vínculo jurídico, como ora propomos.

Àqueles que criticariam esta proposta evidenciadora da presença pública nos contratos da Administração, cabe notar, portanto, que este é apenas o reconhecimento expresso da realidade que já prevalesce.

Por exemplo, Maria João Estorninho, observadora da mutabilidade das fronteiras entre direito público e direito privado, afirma haver uma tendência atual, em certas áreas, à aplicação do direito privado ao agir administrativo, o que denomina de "fuga para o direito privado" 246 . Muito embora concordemos que em certos casos específicos (como nos casos de garantias de financiamentos para Parcerias Público-Privadas, por exemplo) ocorra efetivamente uma maior utilização do direito privado para o agir administrativo do que anteriormente se verificava, nossa opinião é de que não se pode generalizar tal fato a ponto de classificá-lo como uma tendência do direito contemporâneo.

\footnotetext{
244“Art. 79. A rescisão do contrato poderá ser:

I - determinada por ato unilateral e escrito da Administração, nos casos enumerados nos incisos I a XII e XVII do artigo anterior; (...)"

245“Art. 78. Constituem motivo para rescisão do contrato:

(...)

XII - razões de interesse público, de alta relevância e amplo conhecimento, justificadas e determinadas pela máxima autoridade da esfera administrativa a que está subordinado o contratante e exaradas no processo administrativo a que se refere o contrato;"

${ }^{246}$ ESTORNINHO, Maria João. A fuga para o direito privado, cit., p. 379.
} 
Neste sentido, é oportuna a lição de Maria Sylvia Zanella Di Pietro, para quem "por mais que a se idealize a fuga do direito administrativo, ela nunca poderá ser integra, porque, mesmo quando se socorre de institutos do direito privado, tais normas são parcialmente derrogadas pelo direito público ${ }^{, 247}$.

Portanto, nossa proposta não deve ser confundida a uma aplicação maisou menos larga do direito privado aos contratos celebrados pela Administração Pública, nem tampouco com as propostas que proliferam em parte da doutrina contemporânea que sugerem abolir o uso de cláusulas exorbitantes e limitar as prerrogativas públicas. Trata-se apenas de proposta de sistematização das normas de contratação e das cláusulas contratuais típicas destes instrumentos, bem como de reconhecimento da real natureza dos contratos celebrados pelo Estado, sendo que tanto o direito privado quanto o direito público continuarão a ser aplicados na mesma medida em que já o são.

Tal sugestão decorre da constatação (i) de que o regime ordinário privado sempre poderá ser derrogado parcialmente pelo direito público quando se demonstrar que tal derrogação é essencial ao cumprimento de interesse público e (ii) que a discussão acerca da existência de contratos administrativos - a nosso ver desprovida de função prática - se deve, em grande parte, à presença de cláusulas que não são típicas de instrumentos contratuais.

\footnotetext{
${ }^{247}$ DI PIETRO, Maria Sylvia Zanella. O direito administrativo brasileiro sob Influência dos sistemas de base romanística e da common law. Revista Eletrônica de Direito Administrativo Econômico - REDAE, n. 8, 2007. Disponível em: <http://www.direitodoestado.com/revista/REDAE-8-NOVEMBRO-2006MARIA\%20SYLVIA.pdf>. Acesso em: 12 out. 2010. Estas modificações dinâmicas das fronteiras entre o direito público e o direito privado são muito bem notadas por Almiro do Couto Silva, que ressalta que no passado a Escola francesa do serviço público trouxe conceitos típicos do direito privado para o regime jurídico público por meio da criação do conceito de contrato administrativo. Posteriormente, a inadequação dos instrumentos de direito público fez com que se defendesse a aplicação de regras de direito privado no campo do Direito Administrativo. Mais recentemente, com a onda de privatizações verificada na segunda metade da década de 90, a proliferação de concessões fez com que entes de direito privado passassem a ser regidos por normas de direito público (COUTO E SILVA, Almiro do. Os indivíduos e o Estado na realização de tarefas públicas. Revista de Direito Administrativo, Rio de Janeiro, n. 209, p. 68, jul/set. 1997). Não acreditamos que exista uma razão única por trás de tal fenômeno, pois acreditamos que em todos os campos sociais, em todas as relações em que houver ponto de contato entre a Administração Pública e entes particulares, será possível presenciar esta dinâmica viva ao longo dos tempos, como uma decorrência dos anseios sociais e da ideologia predominante. $\mathrm{O}$ que alguns autores - em nossa opinião extremados - classificam de "fugas", "crises" e "derrocadas", acreditamos ser, na verdade, a variação dinâmica e constante de tais fronteiras, consequência do inter-relacionamento entre os ramos do Direito Administrativo e do Direito Civil - pois, como Afonso Queiró já observara, "sendo coisas bem diferentes, a verdade, no entanto, é que o Direito Administrativo e o Direito Privado não estão de costas inteiramente voltadas um para o outro" (QUEIRÓ, Afonso Rodrigues. Lições de direito administrativo. Coimbra: [s.n.], 1976. v. 1, p. 184) -; algo que já ocorre a séculos e que continuará a ocorrer, não se chegando ao tão alarmado fim das instituições de direito estudadas pela doutrina e analisadas pela jurisprudência.
} 
O intuito de se propor alteração visando a preservação da constatação de que os instrumentos que formalizam os negócios jurídicos da Administração Pública são efetivamente contratos é para, com isto, manter-se o consenso sobre a utilização de ato negocial, plutilateral, sinalagmático e que possui uma função social a ser desempenhada: a consecução do interesse público com a preservação dos interesses privados na maior parte possível, além de evidenciar ao particular todos os rsicos de celebrar contrato com o Poder Público.

Além disso, substraindo-se as dúvidas que parte da doutrina ainda insiste em fazer pairar sobre o reconhecimento da natureza contratual de referidos instrumentos, se estará evitando que se utilize a categorização de ato jurídico unilateral para classificar o instrumento jurídico apto a formalizar os negócios jurídicos da Administração Pública, utilização esta que significaria reconhecer que o Estado pode fazer o que bem entender para receber do particular aquilo de que necessita, o que em nada corresponde ao que o ordenamento jurídico pátrio e o direito administrativo permitem. Além disso, modificar a categoria jurídica de tal instrumento (passando-a de contrato para ato unilateral da Administração Pública) seria dar azo à possibilidade de um Estado de império, que abusando de relações verticais se distancia do Estado Democrático de Direito presente na Constituição Federal.

A implementação da proposta traria uma maior transparência ao real alcance das prerrogativas públicas, permitindo ao particular realizar de antemão uma avaliação efetiva do negócio jurídico e, assim, privilegiando a segurança jurídica e o princípio da confiança legítima, que seriam, ademais, reforçados pela intensificação das ações de combate e repressão dos desvios de poder.

Da mesma forma, nos parece ilusório acreditar que é possível reduzir a ação administrativa a uma equação exata, na qual não há espaço para discricionariedade ${ }^{248}$ alguma e onde o risco é diminuto. É fato que negócios jurídicos envolvem risco e, havendo uma maior quantidade de variáveis nos negócios jurídicos envolvendo a Administração Pública, deve-se garantir o seu contraponto compensador. Por mais que se exija a existência de previsão legal detalhada das possibilidades ensejadoras de exercício de prerrogativas, ela nunca o será a ponto de se tornar casuística, pois deixaria sua condição de norma.

\footnotetext{
${ }^{248}$ Cuja importância é enorme, como destaca SOUTO, Marcos Juruena Villela. op. cit., p. 472.
} 


\section{REFERÊNCIAS BIBLIOGRÁFICAS}

ALESSI, Renato. Sistema instituzionale del diritto amministrativo italiano. 3. ed. Milano: Giuffrè, 1960.

ALMEIDA, Fernando Henrique Mendes de. Administração pública no direito privado. Revista de Direito Administrativo, Rio de Janeiro, n. 67.

AMARAL, Diogo Freitas do. Curso de direito administrativo. 2. ed. Coimbra: Almedina, 1994. v. 1.

Direito administrativo. 1. ed. Coimbra: Almedina, 1988, v. 2.

ARAÚJO, Edmir Netto de. Administração indireta brasileira. Rio de Janeiro: Forense Universitária, 1997.

. Contrato administrativo. São Paulo: Ed. Revista dos Tribunais, 1987.

. Curso de direito administrativo. 4. ed. São Paulo: Saraiva, 2009.

Das cláusulas exorbitantes no contrato administrativo. 1986. Tese (Livre Docência) - Faculdade de Direito, Universidade de São Paulo, 1986.

Do negócio jurídico administrativo. São Paulo: Ed. Revista dos Tribunais, 1992. Originalmente apresentada como tese de titular à Faculdade de Direito da USP em 1991.

. Os princípios gerais da licitação. Revista Licitar: licitações, contratos e gestão de suprimentos, São Paulo, v. 1, n. 11, p. 22-31, mar. 1998.

ARRET Epoux Bertin. Disponível em: <http://www.lexinter.net/JPTXT2/arret_epoux_bertin.htm>. Acesso em: 15 set. 2010.

ARRET Société des Granits Porphyroïdes des Vosges. Disponível em: <http://www.lexinter.net/JPTXT2/arret_societe_des_granits_porphyroides_des_vosges.htm>. Acesso em: 15 set. 2010. 
BANDEIRA DE MELLO, Celso Antônio. Contrato administrativo. Revista dos Tribunais, São Paulo, v. 562.

. Curso de direito administrativo. 17. ed. São Paulo: Malheiros Ed., 2004.

. Curso de direito administrativo. 25. ed. São Paulo: Malheiros Ed., 2008.

BANDEIRA DE MELLO, Oswaldo Aranha. Contrato de direito público ou administrativo. Revista de Direito Administrativo, Rio de Janeiro, n. 88, p. 15-33, 1967.

Licitação e contrato administrativo. 13. ed. São Paulo: Malheiros Ed., 2002.

. Princípios gerais de direito administrativo. Rio de Janeiro: Forense, 1969. v. 1.

Princípios gerais de direito administrativo. 3. ed. Rio de Janeiro: Forense, 2007.

v. 1.

BARROS, Sérgio Resende de. Liberdade e contrato: a crise da licitação. Piracicaba: Ed. Unimep, 1995.

BARROS JÚNIOR, Carlos Schmidt de. Contratos administrativos. São Paulo: Saraiva, 1986.

BATISTA JÚNIOR, Onofre Alves. Transações administrativas. São Paulo: Quartier Latin do Brasil, 2007.

BENOIT, Francis-Paul. Le droit administratiffrançais. Paris: Dalloz, 1968.

BERÇAIT, Miguel Angel. Teoría general de los contratos administrativos. Buenos Aires: Depalma, 1952.

BORGES, Alice Gonzalez. A administração pública como locatária. Revista de Direito Administrativo, Rio de Janeiro, n. 201, p. 71-87, jul./set. 1995.

—. Reflexos do Código Civil nos contratos administrativos. Revista Eletrônica de Direito Administrativo Econômico (REDAE), Salvador, n. 9, fev./abr. 2007. Disponível em: <www.direitodoestado.com.br>. Acesso em: 15 ago. 2010. 
BORGES, Alice Gonzalez. Supremacia do interesse público: desconstrução ou reconstrução? Revista Diálogo Jurídico, Salvador, n. 15, jan./mar. 2007. Disponível em: <www.direitopublico.com.br>. Acesso em: 25 jul. 2010.

BREWER-CARÍAS, Allan R. Evolução do conceito de contrato administrativo. Revista de Direito Público, São Paulo, ano 10, v. 51/52, p. 5-19, jul./dez. 1979.

BUCCI, Maria Paula Dallari. Direito administrativo e políticas públicas. São Paulo: Saraiva, 2002.

CAETANO, Marcello. Manual de direito administrativo. 10. ed. Coimbra: Almedina, 1980. t. 1.

CÂMARA, Jacintho de Arruda. Obrigações do Estado derivadas de contratos inválidos. São Paulo: Malheiros Ed., 1999.

CANOTILHO, J. J. Gomes. Direito constitucional e teoria da constituição. 7. ed. Coimbra: Almedina, 2003.

CARVALHAES NETO, Eduardo Hayden. Regulação da universalização de serviços públicos concedidos: o caso brasileiro dos Serviços de Telecomunicações. Dissertação (Mestrado) - Faculdade de Direito, Universidade de São Paulo, São Paulo, 2007.

CORREIA, José Manuel Sérvulo. Os princípios constitucionais da administração pública. In: MIRANDA, Jorge (Coord.). Estudos sobre a Constituição. 2. ed. Lisboa: Livraria Petrony, 1979. v. 3.

COUTO E SILVA, Almiro do. Os indivíduos e o Estado na realização de tarefas públicas. Revista de Direito Administrativo, Rio de Janeiro, n. 209, jul/set. 1997.

CRETELLA JÚNIOR, José. As categorias jurídicas e o direito público. Revista da Faculdade de Direito da Universidade de São Paulo, São Paulo, ano 62, fasc. 2, p. 214, 1967.

As cláusulas "de privilégio" nos contratos administrativos. Revista de Direito Administrativo, Rio de Janeiro, n. 161, p. 7-28, 1985. 
CRETELLA JÚNIOR, José. Direito administrativo comparado. 4. ed. Rio de Janeiro: Forense, 1992.

. Dos contratos administrativos. Rio de Janeiro: Forense, 1998.

- Negócio jurídico administrativo. Revista de Direito Administrativo, Rio de Janeiro, n. 164, p. 29-49, abr./jun. 1986.

. Reflexos do direito privado no direito administrativo. Revista do Direito Civil, Imobiliário, Agrário e Empresarial, São Paulo, n. 2, 1977.

DALLARI, Adilson Abreu. Contrato de obra pública. Cadernos Fundap, São Paulo, ano 5, n. 11, jul. 1985.

DI PIETRO, Maria Sylvia Zanella. Ainda existem os chamados contratos administrativos? In: __ _ RIBEIRO, Carlos Vinícius Alves. Supremacia do interesse público e outros temas relevantes do direito administrativo. São Paulo: Atlas, 2010.

Da aplicação do direito privado no direito administrativo. 1988. Tese (Livre Docência) - Faculdade Direito, Universidade de São Paulo, São Paulo, 1988.

.. Direito administrativo. 16. ed. São Paulo: Atlas, 2004.

. Direito administrativo. 18. ed. São Paulo: Atlas, 2005.

O direito administrativo brasileiro sob influência dos sistemas de base romanística e da common law. Revista Eletrônica de Direito Administrativo Econômico - REDAE, n. 8, 2007. Disponível em: <http://www.direitodoestado.com/revista/REDAE-8-NOVEMBRO2006-MARIA\%20SYLVIA.pdf>. Acesso em: 12 out. 2010.

. Do direito privado na administração pública. São Paulo: Atlas, 1989.

Temas polêmicos sobre licitações e contratos. 5. ed. São Paulo: Malheiros Ed., 2001 .

DINIZ, Maria Helena. Tratado teórico e prático dos contratos. 2. ed. São Paulo: Saraiva, 1996. v. 1. 
DINIZ, Maria Helena. Tratado teórico e prático dos contratos. 5. ed. São Paulo: Saraiva, 2003. v. 5.

DROMI, Roberto. Derecho administrativo. 10. ed. Buenos Aires: Editorial Ciudad Argentina, 2004.

_La licitación pública. 2. ed. Buenos Aires: Astrea, 1977.

_. Temas polêmicos sobre licitações e contratos. 5. ed. São Paulo: Malheiros Ed., 2001.

DUGUIT, Leon. Les transformations du droit public. Paris: Librairie Armand Colin, 1913. Reimpressão La Mémoire du Droit, 1999.

ESTORNINHO, Maria João. Direito europeu dos contratos públicos: um olhar português. Coimbra: Almedina, 2006. A fuga para o direito privado. Coimbra: Almedina, 1999. . Réquiem pelo contrato administrativo. Coimbra: Almedina, 2003.

FAGUNDES, Eduardo Seabra. Contrato administrativo. Cadernos Fundap, São Paulo, ano 5, n. 11, p. 11-16, jul. 1985.

O controle dos atos administrativos pelo Poder Judiciário. 6. ed. São Paulo: Saraiva, 1984.

. Da contribuição do Código Civil para o direito administrativo. Boletim de Direito Administrativo, Rio de Janeiro, ano 2, abr. 1986.

Da contribuição do Código Civil para o direito administrativo. Revista de Direito Administrativo, Rio de Janeiro, n. 78, p. 1-25, 1964.

FIGUEIREDO, Lúcia Valle. Curso de direito administrativo. 3. ed. São Paulo: Malheiros Ed., 1998.

. Curso de direito administrativo. 6. ed. São Paulo: Malheiros Ed., 2003. 
FIGUEIREDO, Lúcia Valle. Extinção dos contratos administrativos. São Paulo: Ed. Revista dos Tribunais, 1986.

FRANÇA, Vladimir da Rocha. Conceito de contrato administrativo. Revista Eletrônica de Direito Administrativo Econômico, Salvador, n. 7, ago./out. 2006. Disponível em: <http://www.direitodoestado.com.br>. Acesso em: 13 nov. 2009.

FRANCO SOBRINHO, Manoel de Oliveira. Contratos administrativos. São Paulo: Saraiva, 1981.

Os contratos administrativos na sua existência jurídico-positiva. Revista de Direito Administrativo, Rio de Janeiro, n. 138, p. 38-39, out./dez. 1979.

. Obrigações administrativas. Rio de Janeiro: Forense, 1983.

FREITAS, Juarez. Estudos de direito administrativo. São Paulo: Malheiros Ed., 1997.

FREITAS, Rafael Véras de. A concessão de florestas e o desenvolvimento sustentável. Revista de Direito Público da Economia - RDPE, Belo Horizonte, ano 7, n. 26, p. 107133, abr./jun. 2009.

FURTADO, Lucas Rocha. Curso de direito administrativo. Belo Horizonte: Forum, 2007.

GARCÍA DE ENTERRÍA, Eduardo; RAMÓN FERNÁNDEZ, Tomás. Curso de derecho administrativo. 1. ed. com notas de Agustín Gordillo. Buenos Aires: La Ley, 2006.

GOMES, Orlando. Contratos. 17. ed. Rio de Janeiro: Forense, 1997. Contratos. 18. ed. Rio de Janeiro: Forense, 1999.

GORDILLO, Agustín. Controle administrativo: regímenes de pago y actualización. Buenos Aires: Ed. Asociacion Argentina de Derecho Administrativo. 1977.

Tratado de derecho administrativo: parte general. Buenos Aires: Macchi. Buenos Aires: F.D.A., 2003. t. 1. Disponível em: <www.gordillo.com>. Acesso em: 26 ago. 2010. Tratado de derecho administrativo: parte general. Buenos Aires: Macchi. 7. ed. Belo Horizonte: Del Rey, 1991. t. 2. 
GRANZIERA, Maria Luiza Machado. Contratos administrativos: gestão, teoria e prática. São Paulo: Atlas, 2002.

GUALAZZI, Eduardo Lobo Botelho. Serviços comerciais, industriais e internacionais do Estado. São Paulo: Ed. Revista dos Tribunais, 1985.

HAURIOU, André. L' utilization em droit administratif dês régles et principes $d u$ droit privé. Paris: Mélanges Gény, 1934. t. 3. Traduzido por Paulo de Mata Machado em Revista de Direito Administrativo, Rio de Janeiro, 1/465, sob o título: Utilização, em direito administrativo, das regras e princípios do direito privado.

JÈZE, Gaston. L'application dês régles de droit privé aux manifestations unilaterales ou contractuelles de volonté de droit public. Revue de Droit Public, t. XL, 1923.

Les príncipes généraux du droit administratif. 3. ed. Paris: Dalloz, 2004, t. 3.

JUSTEN, Mônica Spezia. A noção de serviço público no direito europeu. São Paulo, Dialética, 2003.

JUSTEN FILHO, Marçal. Comentários à Lei de Licitações e Contratos Administrativos. 7. ed. São Paulo: Dialética, 2000.

Comentários à Lei de Licitações e Contratos Administrativos. 9. ed. São Paulo: Dialética, 2002.

. Comentários à Lei de Licitações e Contratos Administrativos. 13. ed. São Paulo: Dialética, 2009.

. Curso de direito administrativo. 4. ed. São Paulo: Saraiva, 2009.

. Teoria geral das concessões de serviço público. São Paulo: Dialética, 2003.

LAMARQUE, Jean. Recherches sur l'application du droit privé aux services publics administratifs. Paris: Librairie Génerale de Droit et de Jurisprudence, 1956. v. 1.

LAUBADÈRE, André de. Traité théorique et pratique des contrats administratifs. Paris: Librairie Générale de Droit et de Jurisprundence, 1956. t. 1. 
LAUBADÈRE, André de; VENEZIA, Jean-Claude; GAUDEMET, Yves. Droit administratif. 17. ed. Paris: L.G.D.J., 2002.

LIMA, Ruy Cirne. Contratos administrativos e atos do comércio. Revista de Direito Administrativo, Rio de Janeiro, Seleção histórica, p. 271-281, 1945-1995.

Contratos administrativos e atos do comércio. Revista de Direito Administrativo, Rio de Janeiro, n. 32, p. 16-26, 1953.

Direito administrativo e direito privado. Revista de Direito Administrativo, Rio de Janeiro, n. 62, p. 1-13, p. 1960.

LONG, Marceau; WEIL, Prosper; BRAIBANT, Guy; DELVOLVÉ, Pierre; GENEVOIS, Bruno. Les grands arrêts de la jurisprudence administrative. Paris: Dalloz, 1996.

MACHADO, Paulo de Mata. Utilização, em direito administrativo, das regras e princípios do direito privado. Tradução de HAURIOU, André. L' utilization em droit administratif dês régles et principes du droit privé. Aris: Mélanges Gény, 1934. t. 3. Revista de Direito Administrativo, Rio de Janeiro, n. 1, fasc. 2, p. 465, 1945.

MARQUES NETO, Floriano de Azevedo. O regime jurídico das utilidades públicas: função social e exploração econômica de bens públicos. 2008. Tese (Livre Docência) Faculdade de Direito, Universidade de São Paulo, São Paulo, 2008.

. Parecer sobre "Alteração de contrato administrativo - antecipação de etapas de execução - Intangibilidade das condições econômicas e financeiras originais - Alteração de regime de execução e pagamento como fator de neutralização dos ônus excedentes Noção jurídica da ‘Antecipação de pagamento' Vedada em lei”. Revista Interesse Público, Belo Horizonte, n. 14, p. 66-79, maui/jun. 2002.

Regulação estatal e interesses públicos. São Paulo: Malheiros Ed., 2002.

MARTINS, Ricardo Marcondes. Contratos administrativos. Revista Eletrônica de Direito do Estado - REDE, Salvador, n. 17, p. 33-38, jan./mar. 2009. Disponível em: <www.direitodestado.com.br/rede.asp>. Acesso em: 13 mar. 2010. 
MAURER, Hartmut. Direito administrativo geral. Tradução de Luís Afonso Heck. Barueri: Manole, 2006.

MAYER, Otto. Derecho administrativo alemán. Tradução de Horacio H. Heredia e Ernesto Krotoschin. Buenos Aires: Depalma, 1949. t. 1,.

MEDAUAR, Odete. Direito administrativo moderno. 13. ed. São Paulo: Ed. Revista dos Tribunais, 2009.

MEIRELLES, Hely Lopes. Direito administrativo brasileiro. 8. ed. São Paulo: Malheiros Ed., 1981.

. Direito administrativo brasileiro. 18. ed. São Paulo: Malheiros Ed., 1998.

. Direito administrativo brasileiro. 28. ed. São Paulo: Malheiros Ed., 2003.

. Licitação e contrato administrativo. 13. ed. São Paulo: Malheiros Ed., 2002.

MOCADA, Luís Solano Cabral. O problema do critério do contrato administrativo e os novos contratos-programa. Boletim da Faculdade de Direito da Universidade de Coimbra, numero especial, estudos em homenagem a J.J. Teixeira Ribeiro, Coimbra, n. 2, p. 585637, 1979.

O problema do critério do contrato administrativo e os novos contratos-programa. In: . Estudos de direito público. Coimbra: Coimbra Ed., 2001.

MONEDERO GIL, José Ignácio. Doctrina del contrato del Estado. Madrid: Instituto de Estudios Fiscales, 1977.

MOREIRA NETO, Diogo de Figueiredo. Apontamentos Sobre a reforma administrativa. Rio de Janeiro: Renovar, 1999.

O futuro das cláusulas exorbitantes nos contratos administrativos. In: ARAGÃO, Alexandre Santos de, MARQUES NETO, Floriano de Azevedo (Coords.). Direito administrativo e seus novos paradigmas. Belo Horizonte: Fórum, 2008. p. 571-592. 
MOREIRA NETO, Diogo de Figueiredo. O futuro das cláusulas exorbitantes nos contratos administrativos. Revista da Associação dos Procuradores do Novo Estado do Rio de Janeiro, Rio de Janeiro, n. 17, p. 3-22, 2006.

MUKAI, Toshio. Contratos públicos. Rio de Janeiro: Forense Universitária, 1995. Licitações e contratos públicos. 5. ed. São Paulo: Saraiva, 1999. O novo Estatuto Jurídico das Licitações e Contratos Administrativos. São Paulo: Saraiva, 1993.

PALERMO, Fernanda Kellner de Oliveira. Escorço histórico do contrato administrativo. Jus Navigandi, Teresina, ano 7, n. 54, 1 fev. 2002. Disponível em: $<$ http://jus.uol.com.br/revista/texto/2647>. Acesso em: 05 nov. 2010.

Regime jurídico público e privado nos contratos administrativos: pontos de aproximação e afastamento. Rio de janeiro: Lumen Juris, 2008.

PÉQUIGNOT, Georges. Des contrats administratifs. Paris: Librairies Techniques, 1953.

PONDÉ, Lafayette. A vontade privada na formação ou na eficácia do ato administrativo. Revista de Direito Administrativo, Rio de Janeiro, n. 63, p. 17, jan./mar. 1961.

QUEIRÓ, Afonso Rodrigues. Lições de direito administrativo. Coimbra: [s.n.], 1976. v. 1.

REALE, Miguel. Função social do contrato. Disponível em: <http://www.miguelreale.com.br/artigos/funsoccont.htm>. Acesso em: 24 ago. 2010.

RETORTILLO, Sebastián. Il diritto vivile nella genesi del diritto amministrativo e dei suoi Iistituti. Rivista Trimestrale di Diritto Pubblico, Milano, v. 9, 1959.

REVISTA de Direito Administrativo, Rio de Janeiro, v. 215, p. 240-245. 1999.

RIVERO, Jean. Droit administratif. 5. ed. Paris: Dalloz, 1971.

ROUVIÈRE, Jean. Les contrats administratifs. Paris: Dalloz, 1930.

SALGADO FILHO, Nilo Spínola. Contrato administrativo: efeitos da invalidação. 2006. Dissertação (Mestrado) - Faculdade de Direito, Universidade de São Paulo, São Paulo, 2006. 
SANTOS, Márcia Walquíria Batista dos. Cláusulas exorbitantes: da teoria à prática. In: DI PIETRO, Maria Sylvia Zanella; RIBEIRO, Carlos Vinícius Alves. Supremacia do interesse público e outros temas relevantes do direito administrativo. São Paulo: Atlas, 2010.

SAVATIER, René. Du droit civil au droit public. Paris: Librairie Génerale de Droit et de Jurisprudence, 1945.

SOUSA, Marcelo Rebelo de; DE MATOS, André Salgado. Contratos públicos: direito administrativo geral. Lisboa: Dom Quixote, 2008. t. 3.

SOUTO, Marcos Juruena Villela. Direito administrativo contratual. Rio de Janeiro: Lumen Juris, 2004.

SUNDFELD, Carlos Ari. Direito administrativo ordenador. 1. ed. São Paulo: Malheiros Ed., 1997.

Licitação e contrato administrativo de acordo com as Leis n. 8.666/93 e 8.883/94. São Paulo: Malheiros Ed., 1994.

; CÂMARA, Jacintho Arruda. O cabimento da arbitragem nos contratos administrativos. Revista de Direito Administrativo, Rio de Janeiro, n. 248, p. 117-126, maio/ago. 2008.

TÁCITO, Caio. Contrato privado da administração. Exportação de açúcar. In:

Temas de direito público: estudos e pareceres. Rio de Janeiro: Renovar, 1997. v. 2.

Contratos administrativos. Revista de Direito Público, São Paulo, v. 18, out./dez. 1971.

Direito administrativo e direito privado nas empresas estatais. Revista de Direito Administrativo, Rio de Janeiro, 151/22-28.

TELLES, Inocêncio Galvão. Manual dos contratos em geral. 3. ed. Lisboa: Lex, 1965.

VEDEL, Georges; DELVOLVÉ, Pierre. Droit administratif. 12. ed. Paris: Presses Universitaires de France, 1994. v. 1. 
VENOSA, Sílvio de Salvo. Direito civil: teoria geral das obrigações e teoria geral dos contratos. São Paulo: Atlas, 2002. t. 2.

VIANA, Cláudia. Os princípios comunitários na contratação pública. Coimbra: Coimbra Ed., 2007.

WALINE, Marcel. Précis de droit administratif. Paris: Montchrestien, 1969. v. 1. 